
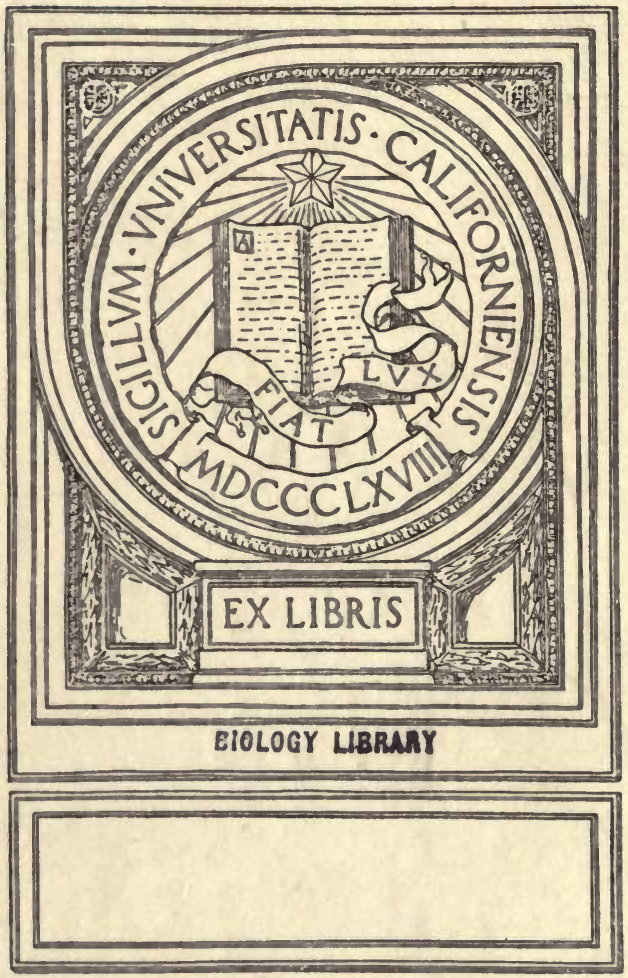


\section{WILD LIFE ON THE WING}


UNIFORM WITH THIS VOLUME

\section{HIGHWAYS AND BYWAYS OF THE ZOOLOGICAL GARDENS}

By C. INNES POCOCK

Containing Thirty-two full-page Illustrations from Photographs

\section{THE MOOSE}

By Agnes Herbert

Containing Eight full-page Illustrations by PATTEN Wilson

A. AND C. BLACK : 4 SOHO SQUARE : LONDON W

AMERICA . . . THE MACMILLAN COMPANY

64 \& 66 FIFTH AVENUE, NEW YORK

AUSTRALASIA. . THE OXFORD UNIVERSITY PRESS

205 FLINDERS LANE, MELBOUR NE

CANADA, 2 THE MACMILIAN COMPANY OF CANADA ITD

ST. MARTIN'S HOUSE, 7 O BOND STREET, TORONTO

INDIA .... MACMILLAN \& COMPANY LTD

MACMILLAN BUILDING, BOMBAY

309 BOW BAZAAR STREET, CALCUTTA 


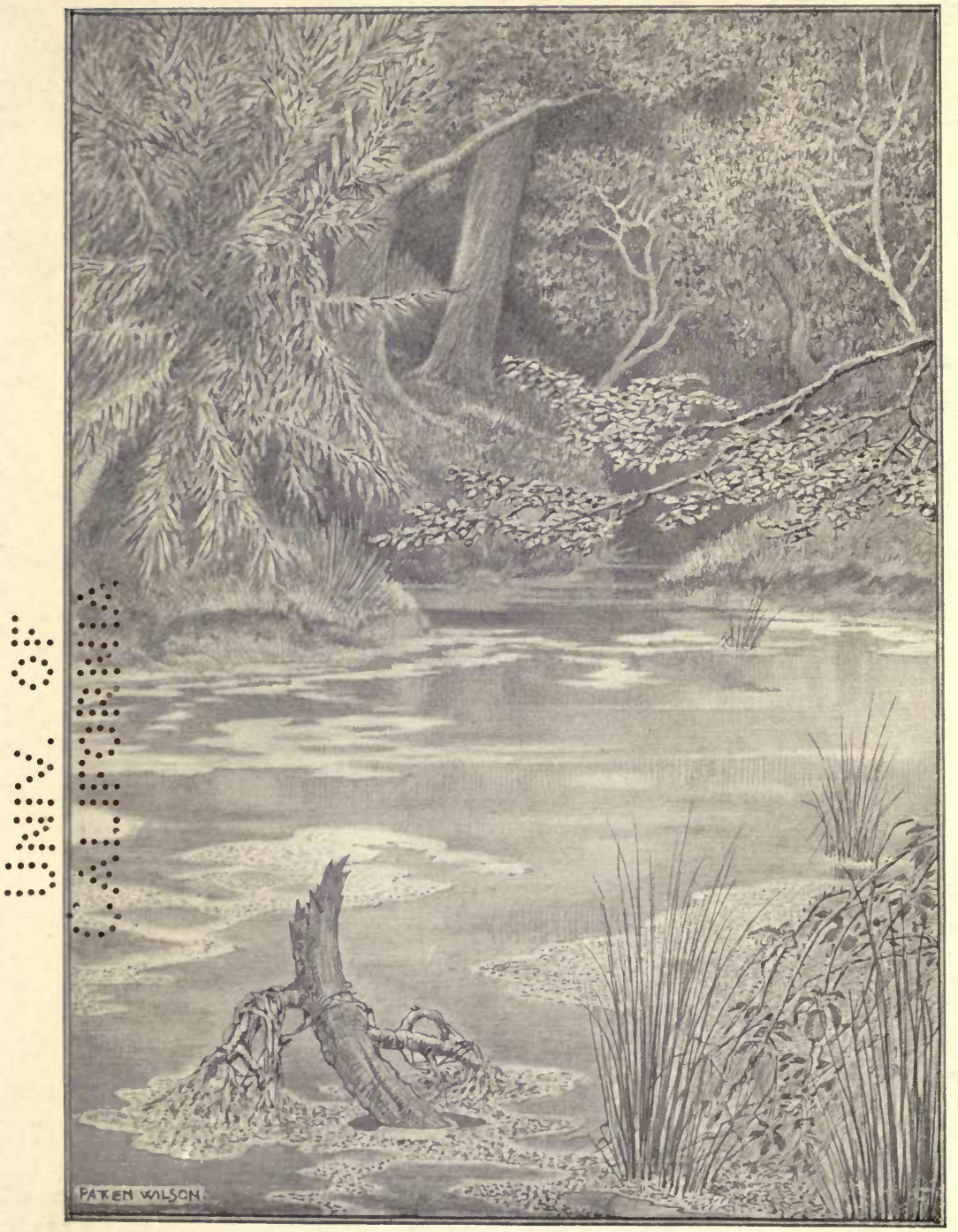

THE HEAD OF THE POOL 


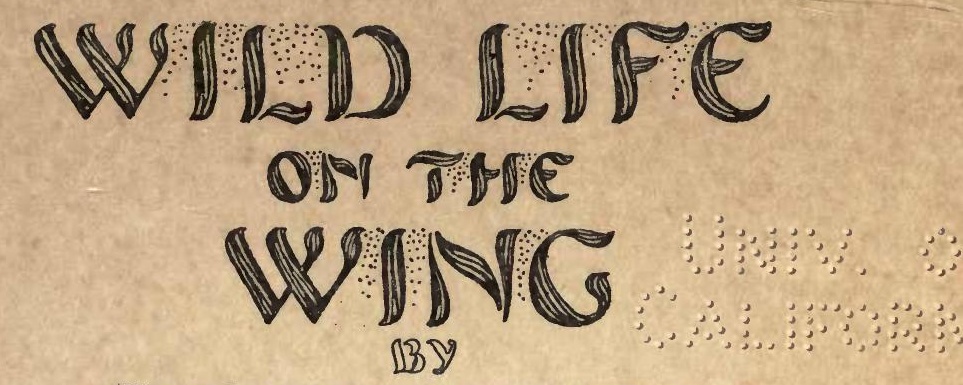

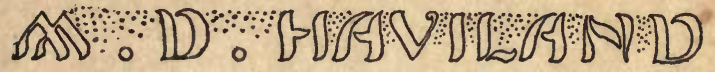

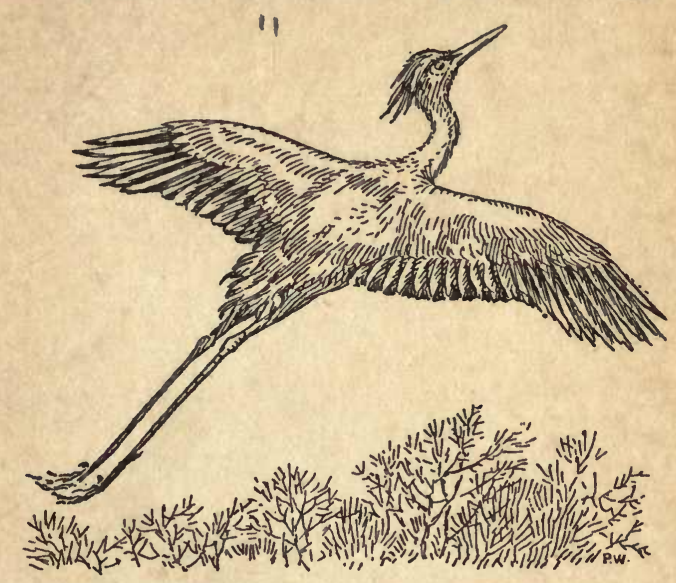

WITH 8 FULJPAGE, 50 SMALLER DRAWINGS IN THE TEXT BY

PAITEN WILSON

पQ口了

[ONDON

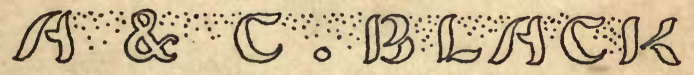




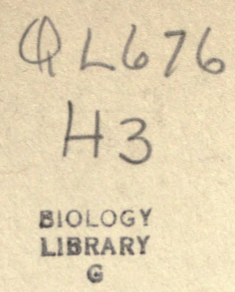

TO

MR. DOUGLAS ENGLISH

THE FIRST OF MY CRITICS-

AND THE KINDEST

EIOLOGY LIBRARY 


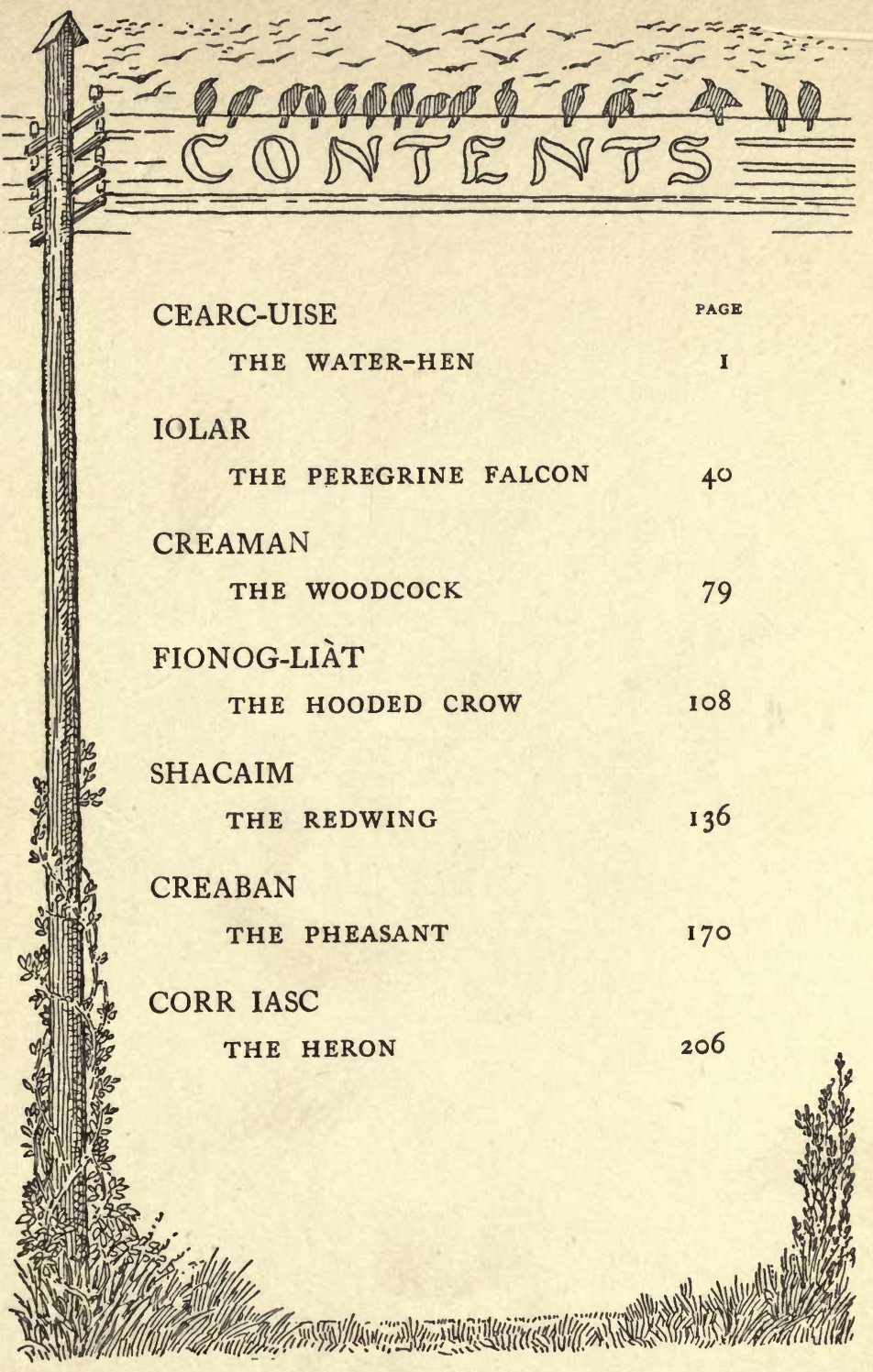





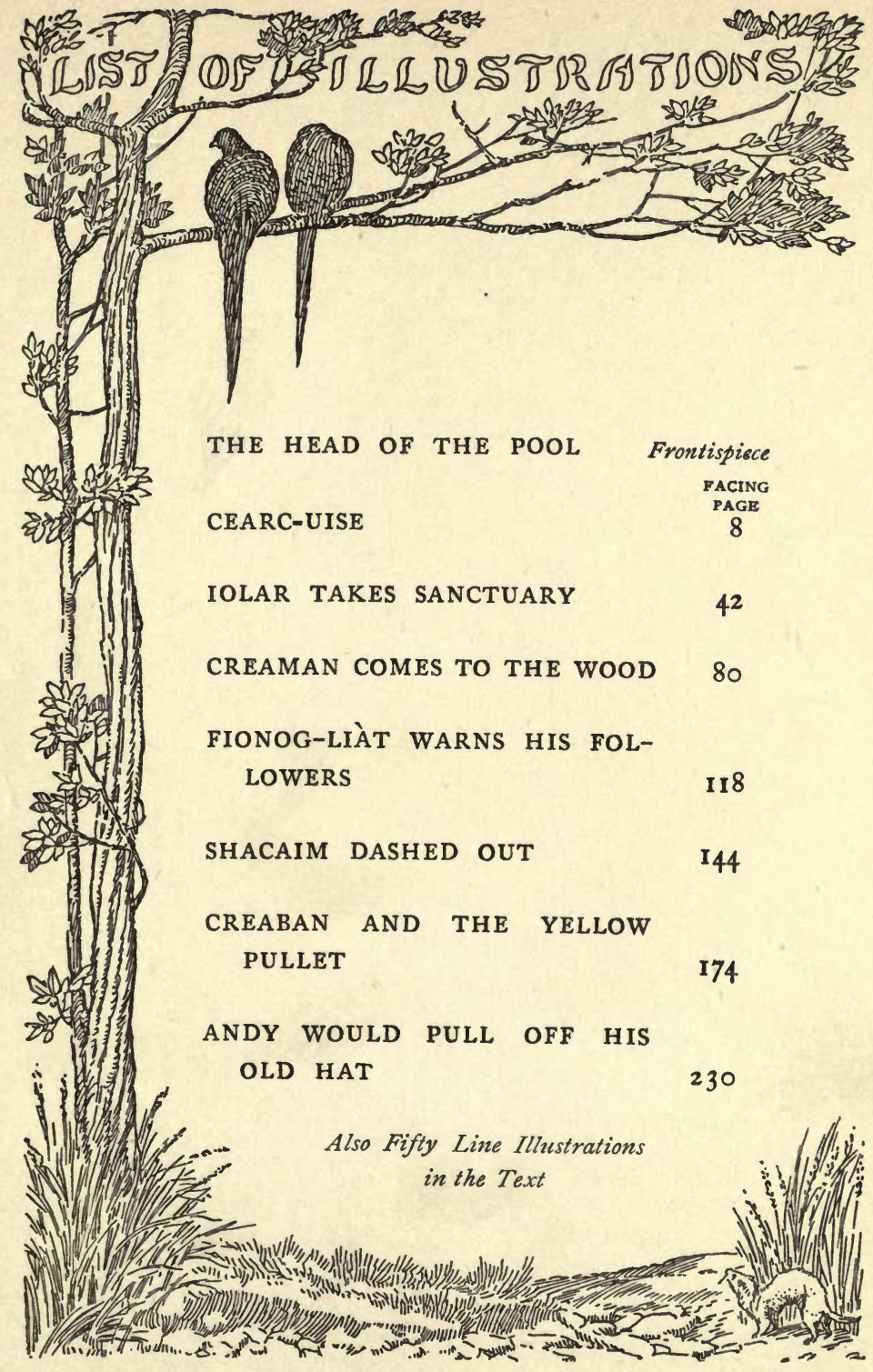





\section{OF CEARC-UัISE THE WATER-HEN}

Go down the hill, bearing south of the Old Fort. So, you cannot well miss the Dark Pool; but should you by mischance do so, wait until dusk, and then I warrant that the first of the wood-people you shall meet will show you the way thither. There is a little stream which rises under the wall of the Fort (it used to run red in the old days) and the hunters and the hunted alike follow the loud magic of the running water, and so come to the more silent, yet not less potent magic of the Dark Pool, round which so many of the wood lives have been lived. But when the stream at last reaches the Dark Pool there is no more noise or babble, but only two or three rings of foam over the starwort beds, to show which way the current runs.

Most of the wild people prefer to drink at the stream's source rather than lower down. There are thorn bushes all round the Pool, and 


\section{WILD LIFE ON THE WING}

behind them grow tall trees, so that in the evening one can only tell that the sun has set by: the fading of the light in the sky. There is neither moonirise nor moonset for the people of the Pool, for they cannot see the moon unless she is right overhead. Perhaps it is because it was so dark that the woodfolk did not like the Pool. The hunting paths turned eastward, fifty yards from the place; and the Fur Folk never lay out to sun themselves on its banks, because by the time the sun was high enough to warm the water they must return to their lairs. I have seen honeymooning teal swoop down, and then sheer off at an alder's height from the water, fearful of what might lurk in the thick covert round the edge; and no rabbit loitered by the Pool, but passed on quickly. The Dark Pool had a sinister name in the woods. When a rare sunbeam struck aslant the water under the overhanging branches at the north side, something white glimmered on the muddy bottom. That is why the foxes never drank at that end of the Pool-the water was fouled. Ever since the cord which bound it to an anchoring stone had loosened, a certain shapeless thing floated just awash under the briars: it waited its time to sink down among other stones and the white bones which had been consigned at different 


\section{THE WATER-HEN}

times to the keeping of the water. Perhaps that is why the Fur Folk did not drink there -they recognized their kinsmen.

Few flowers grew round the Pool, and the birds did not often sing there. Rushes and marshwort and green things of that kind grew on the south and west sides where the water was shallow, and long shoots of ivy hung down and stirred the surface.

The people of the Pool were quiet, like the place. The rats who lived under the blackthorn roots along the bank were sleek and well-fed; the herons, who sometimes went a-fishing there on still afternoons, were silent anglers: there were few fish in the Pool except the eels who battened in the mud, and grew as fat as the rats-often upon the same fare.

The Dark Pool was the only pond in the countryside which seldom owned a pair of moorhens. Two summers before the year of which I write a pair had nested upon it; and sometimes at noon the rats sunned themselves on the remains of the old nest which their fathers had so persistently robbed that the birds had become disheartened and returned to the river. The preceding summer no moorhens had visited the place, or else, noting its gloom and the banks confined by undergrowth, they had departed at once. Hence, as the 


\section{WILD LIFE ON THE WING}

Dark Pool is properly a very silent place, and its glass-black surface inviolate from hour to hour, the badgers, harvesting moss on the hill, snuffled with astonishment one March night when they heard a moorhen take seizin of the water. And this was the fashion of it. $\mathrm{He}$ crossed it from end to end with a flourish, and landed under the alder-tree rocking upon waves of his own raising. Then, after a pause to add to the effect, he cried aloud his name far and near: "Karruck!" The badgers heard it : the white owl heard it : the lusty west wind caught it and whirled it along the hillside as far as the fox earth in Grenogue Wood; and there the vixen slinking into her newly dug " earth" heard it, and pricked up her ears. Thus the woods learned that the moorhen had taken possession of the Pool once more, for that is his way of staking his claim.

\section{II}

The rats, grooming their whiskered faces outside their holes next morning, looked askance at the newcomer, for it was a long time since their peace had been disturbed. Karruck took breakfast among the floating crowfoot, and then studied his surroundings. There was already bloom on the blackthorns on the hill, but down 


\section{THE WATER-HEN}

by the waterside the buds had not yet broken, for, although the sun was well above the horizon, the long pale shadows of the trees lay across the place, and the sun would not shine upon it fully until nearly noon. But the fine March day, with the wind rollicking through the tree-tops, made even the Dark Pool wholesome and good to live in, and the fat tench who lived in the mud at the bottom began to wake up from their winter lethargy. But all that day no other waterbird came, except Glasóg, the Wagtail, who runs where she likes. The river runs north and south through the meadows, but a quarter of a mile of wood and open grass land divides it from the Pool. In still weather the roar at the weir can be heard plainly, and throughout the day Karruck listened to the challenging crowing of other moorhens. In the evening he landed and ran along the bank. There was a moon for the most part muffled in clouds, and a little wind whined through the trees. He went up the stream bed to where the water trickled sheer over a six-foot rock to the slimy green stones underneath. At the foot of the cascade there was scarcely enough water to wet his red garter-bands, but it made a prodigious splash upon the stones, 


\section{WILD LIFE ON THE WING}

and his feathers were spangled with spray. It was a dark place, for the thorn-trees met overhead. Far away a flock of curlew called, and then life in the woods, from Grenogue to the river bank, began to move quietly. A rustle in the bushes meant that the rabbits were driving new shafts into the hillside, a distant cry in the wood told of the foxes' hunting, and only the wind knew how many of the Feather Folk were travelling just under cloud-level that night. Karruck listened, then rose tip-toe, and cried his name shrilly. A woodcock swung chissicking over the trees, but there was no reply. He called a second and then a third time-half challenge, half love note, as liquid as the dripping of the stream. Then the answer came, but not in the way that Karruck expected, for as he stood curtseying with expectation, something crashed into the branches above him, slithered awkwardly through the twigs, and dropped into the water. Even in the gloom he recognized a wide liquid eye like his own, and twitching tail-coverts, white as the foam-flakes which eddied by. That much he saw, and then, with a startled "kek-kek," she flew downstream. He tried to follow and lost himself in the tangle overhead. But as he struggled up through the branches the moon came out. He saw the broad silver shield of light which 6 


\section{THE WATER-HEN}

it cast upon the Pool all at once shiver into a hundred ripples, and heard a faint splash as she alighted. Then he followed at his leisure, for he knew that the magic of the Pool would keep her until morning.

\section{III}

This is more a tale of Karruck's mate than of Karruck himself. She was Cearc-uise, the water-hen from the weir-side; and whether she came to Dark Pool by chance, or in answer to Karruck's call, is not known, but the chronicler suspects the latter.

Karruck was astir early, and before it was light he had proclaimed the Pool, and all that was in it, as his own, that she might hear. Therefore, when he swam across the open water at dawn, she shifted from one perch to another, so that by the ring of ripples he might know where she was hidden. A wooing which might have been long and perplexed on the crowded river, was short enough in the loneliness of the Pool. . . . They swam slowly across the open water, side by side, and landed on one of the shelving mud ledges which the rats had trodden smooth. They stood shoulder to shoulder, duplicated in the clear water at their feet, and discoursed in that soft language which 


\section{WILD LIFE ON THE WING}

the Feather Folk only use in the love season. Karruck stiffened his throat and crowed again triumphantly, while Cearc-uise, his mate, preened her ample breast. Then a little spring wind ruffled the surface of the Pool, and the two reflections were no longer separately clear, but blurred and confluent. So, they made their Eden, and its bliss was not the less profound that at any minute of their intercourse unexpected and pressing danger might threaten them. For three days they were unmolested : then the serpent came, not subtly, as of old, but blatantly, with force. On the third morning Karruck woke with a repetition of his own challenge in his ears, and found that the Pool-the Pool which was his by all the rights of prior possession-was invaded, and the intruder was paddling placidly about his favourite shallows. Cearc-uise also saw, and her mate knew it. He flew across the Pool with claws spread, and fairly dousing the newcomer as he passed, he dropped clucking on to the bank with his feathers indignantly puffed out to await the counter-attack.

They threw themselves backwards on their outstretched wings. This is the approved moorhen fashion, effective in water, but less so on land. Each saw in perspective his rival's red frontal plate guarded by hooked claws, and 8 


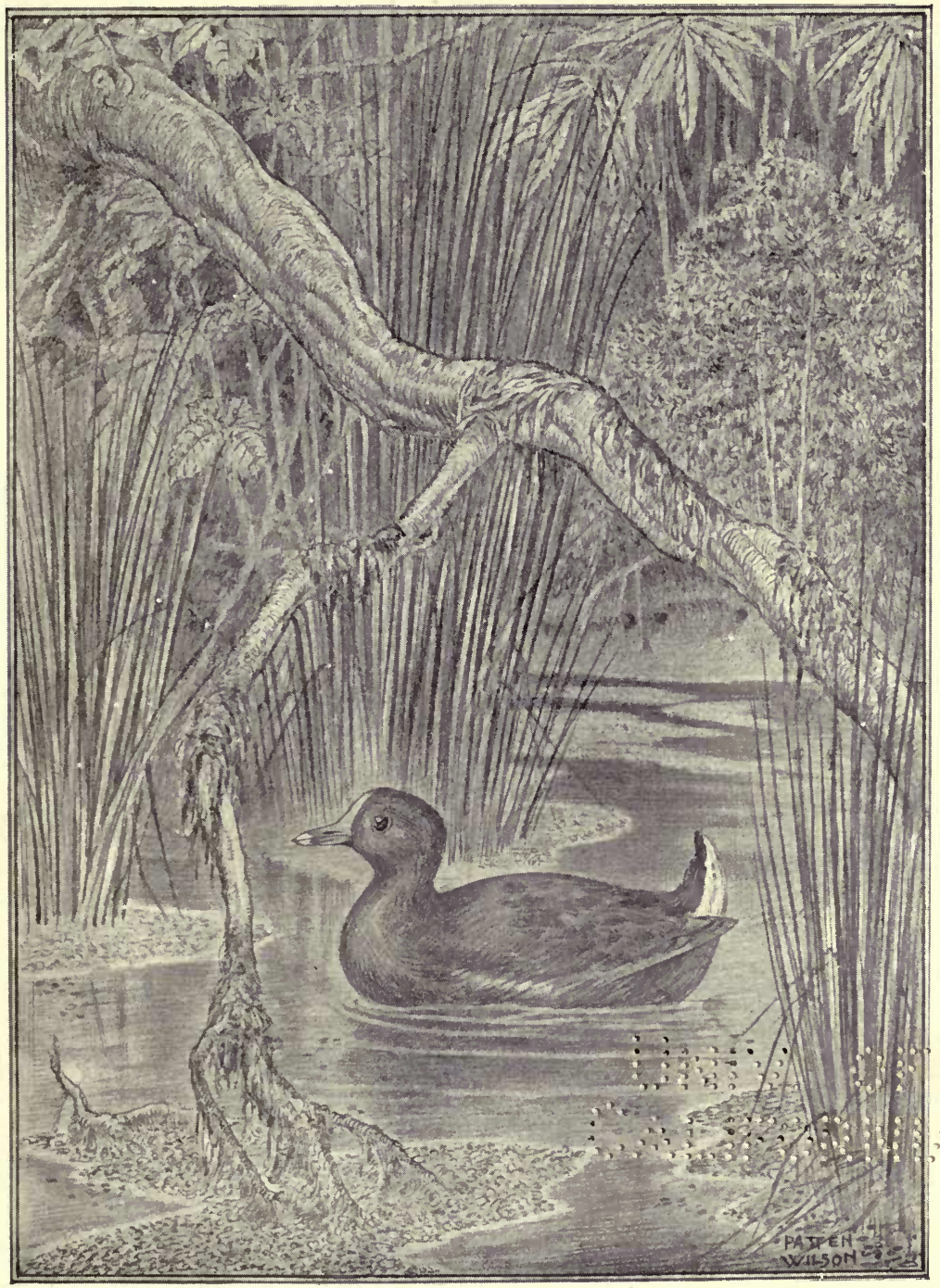


औ

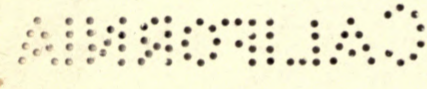


struck at it. Feint and cut and feint. Cearcuise, "kek-keking" hysterically, swam up and down as they flapped on the grass. Karruck was nearest the edge, and before he was aware of his danger he was driven backwards into the water. Immediately the other was upon him, and buffeted him with feet and pinions. One claw ripped Karruck's wing underneath where the feathers were soft, and striking the hard bone numbed the limb. Karruck, halfdazed, turned and fluttered unsteadily ashore. The victor crowed a defiance across the Pool: Cearc-uise submitted willy-nilly, for such is wood law.

For two days and a night the dominion of the Pool was usurped. Karruck nursed his torn wing, and only ventured out to feed or bathe when his enemy was off guard. The bully was a heavy bird, for he had wintered among the sheltered islands below the Mill; and though there were skirmishes almost every hour, Karruck was hunted away every time, for his wing was still stiff and unserviceable. The second day was wet, and then both parties skulked in the rushes, for they could not fish in the rain-dappled Pool. Several times Cearcuise came out and headed towards the crooked alder where Karruck had taken covert, but 


\section{WILD LIFE ON THE WING}

every time the conqueror pushed out of the rushes, and, by pestering her with his unwelcome attentions, drove her in again.

Karruck would have left the Pool on the second night if the skies had been darker, or if the wind had blown from another quarter, but the clouds lifted at sunset, and the damp spring smells of the warm night held him. Therefore he saw how the usurper and Cearcuise went slowly up the stream into the wood. $\mathrm{He}$ himself stayed in the Pool ; but later, when his rival crowed a defiance, for the first time since his defeat, he answered as lustily as ever.

With the mirroring of the first star in the water a fox barked up on the hill. Then there was silence over all the woods for half an hour. Only the stream, swollen a little with the recent rain, trickled into the Pool with a tinkle like knowing laughter.

Suddenly Cearc-uise, "keking" frantically, whizzed overhead like a driven grouse, and splashed into the most secret covert in the Pool. Karruck heard a fainter splash up the stream, almost like an echo, and then a strangled shriek. $\mathrm{He}$, in his turn, hid himself with fear.

Presently two dusky feathers floated down the stream. The water seemed to babble louder as it brought them to the Pool again. Perhaps 


\section{THE WATER-HEN}

to those who understood it, it may have talked of the fox's former raids, and of how any moorhen who wintered on the Pool never saw New Year's Day. And all the while the blackthorn bushes, which afforded the fox such safe covert for his hunting, sang wicked little songs as the wind blew through them. But Karruck did not hear, because by that time he was in the rushes with Cearc-uise.

\section{IV}

They built the first nest at the deeper end of the Pool, among some drooping branches. The evening on which the first egg was laid they fed together up the streamside, and just returned in time to see the magpie depart with their treasure transfixed on his bill. Cearcuise grieved a great deal, but she laid another in the same nest, and the magpie stole that one also. However, on the third day the thief went to join some of his relations, who swung on a tree behind the gamekeeper's cottage ; but Cearc-uise was much too scared to use that nest again, and so they planned another. This time they chose the alder at the east side of the Pool, in order that its branches might to a certain extent screen their nest from passing thieves. All the time that the nest was being built 


\section{WILD LIFE ON THE WING}

the Pool grew deeper, until there were quite three feet of water under the foundations. Every evening saw the task almost completed, but each morning more flotsam must be added to make good the rise of the water during the night. At last it was finished, however, and then Cearc-uise began to sit upon six eggs.

It was then that she found out how gloomy and how shut in by trees the Dark Pool was. Hemlocks pushed their way up among the bushes: they each showed a tuft of plumy green leaves, but last summer's dead stalks still stood up stiffly like dry bones. A man could not have pushed through the brittle stems without alarming the whole woodside, but other quieter people, every whit as dangerous, hunted through them nightly.

April was often wet, but towards the end of the month the weather gradually cleared up, and sometimes the sun shone in the middle of the day. Karruck used to go and sun himself on the south side of the Pool where there was a little grassy place which the rabbits kept gnawed smooth; but Cearc-uise could not leave her eggs, and she only enjoyed the sunshine for a quarter of an hour at midday, when the beams found their way through the branches overhead and warmed her a little.

She sat so closely that on the tenth day she was I 2 


\section{THE WATER-HEN}

quite thin, and her breast-feathers were worn with much shifting over the eggs. Karruck sat beside her until sunset, and then swam over to supper on the marshwort beds. There was a bramble bush close to the bank, and Karruck did not notice that the hedgesparrow who owned it, flew out with a lamentable chirp. However, the vixen sprang the fraction of a minute too soon, and her teeth snapped just behind Karruck's tail as he scudded away. Cearc-uise tumbled off her nest and hid under the bank. The vixen plunged belly deep into mud and water, but picked herself out daintily and hopped back to covert. The Pool rippled to placidity again, and then, although she was badly frightened, Cearc-uise remembered her cooling eggs, and paddled slowly towards the nest. It was dusk under the alder. Cearc-uise was just about to clamber inside when she suddenly saw the vixen on the bank above. Cearc-uise sank her body low in the water until it looked like a piece of floating wood, and tried to paddle herself gently into safety, but a tell-tale ripple spread along the surface, and the vixen's quick eye saw it. She whimpered, and stretching sideways, tried to reach the bird without slipping into the water herself. Cearc-uise took a header, and so passed from under her jaws by the way of the cool underwater world to the alder's shade. 


\section{WILD LIFE ON THE WING}

There she took breath under cover of a lump of flotsam, and hid until the vixen had shaken herself and trotted away up the stream.

But, long after she was dozing on her eggs again, the water gurgled as if it were laughing to itself as it smoothed out the little pits which the vixen's pads had pressed in the mud.

\section{V}

There were four hungry cubs in the "earth" in Grenogue Wood that spring, and as their mother licked the mud off her coat that night she determined to hunt by the Pool again. Therefore she went by starlight the next night, and Cearc-uise saw her steal down to the water's edge and gauge the distance to the nest. The alder jutted out like a crooked elbow, padded with moss and black mould, and the Pool had been full of water for so long that the trunk was almost submerged. The nest was about six feet from the bank, and built solidly; but whereas on the previous day the waterline had reached to within a few inches of the brim, to-day it had fallen a little. The vixen put her forepads on the alder trunk, whispering a little at the cold water. Cearc-uise flung herself off the nest and tried the old pretence of threshing the water with a wounded wing, and the vixen, 
THE WATER-HEN

falling into the trap, allowed herself to be decoyed away for the time being. But for the rest of the night Cearc-uise only dared to doze fitfully on her eggs, and woke in dread lest fierce, inquisitive eyes should be upon her.

On that day, the thirteenth of Cearc-uise's brooding, the skies were cloudless, and even the Dark Pool was warm, but the water sank lower still. Cearc-uise was restless and nervous, and spent more time than she should have done in patrolling the Pool.

It was a race between the hatching of the eggs and the subsidence of the Pool; for the vixen knew of the nest, and would come again and again until it was stranded high and dry, and then, without the protection of the surrounding water, it would no longer be safe to cover the eggs at night. In the evening Karruck came and dozed on a branch beside the nest, and it was well that he did so, for he gave the alarm, and Cearc-uise woke to see the vixen on the bank. Her jowl was red after successful hunting, and as she eyed the coveted game the saliva dribbled from her mouth with 


\section{WILD LIFE ON THE WING}

anticipation. Cearc-uise struck a fighting attitude over her eggs while the vixen delicately tested the depth of the water. However, though it was shallow enough under the bank, she dared not risk a spring into unknown depths, and curbed her impatience yet once more.

\section{VI}

That was the fourteenth day, and the moorhens realized that something must be done, for the water was falling hourly, and there was no sign of rain. They began to build a refugenest, where the chicks-to-be might nest and bask safely in the sun, and the rats watched them solemnly. Karruck did most of the work because his mate was sitting so closely.

The vixen came again that night, and the water was so low that she stood high and dry on the crooked alder trunk and tested a long branch which stretched out towards the nest, but it was slippery and yielding, and she drew back.

All the next forenoon Karruck worked at the new refuge-nest in a desultory way. The first essay did not please him, so he began two others, and abandoned them after an hour's work. In the evening Cearc-uise went over and helped him to lay deeper foundationsI6 


\section{THE WATER - :HEN}

diver's work, that; half the time she lay with her head under water.

On her way back she had premonitions of disaster. Surely that was not a twig which dangled from the nest brim? She took wing, and bounced into the nest on top of the rat. $\mathrm{He}$, cowering under buffeting wings and claws, had no choice but to defend himself. He knew that he might as well have bitten on a cuirass as on her close breast feathers, but as she turned on her back to strike, as moorhens will, his teeth nipped under her wing. Cearcuise flung herself into the water, and the rat, glad to escape so easily, dived away at once, while she swam screaming up and down the Pool.

She dared not go back to the nest. All the hunters from Grenogue to the river knew about it. It was a pillory where they might watch her meaningly where she sat, as they waited while her protector, the water, dwindled. The trees were in leaf now, and shut off what little light was reflected from the sky to the Pool. The surface of the water was as smooth as pitch and as black, but even in the darkness Cearc-uise dared not go back to that nest. The second rat slipped through the water with scarcely a ripple, but she felt the gentle current of his passage. Every fibre in her had been 


\section{WILD LIFE ON THE WING}

set on edge by her last alarm, and her first impulse was to hide under the bank and leave the eggs to their fate, but all the awakening mother-love in her rose up to combat the desire. Instead, she swam boldly up and stepped boldly on to her eggs, clucking softly, and the rat sheered off discreetly at her approach.

She sat down quietly and listened to the chorus of complaint and anticipation which came from the chipping eggs under her breast, but all the while she glanced behind her lest the rat, or the fox perhaps, should spring upon her from behind.

The Dark Pool shrank still more during the night, and in the morning there was only a paltry channel of muddy water eighteen inches wide to separate the nest from the bank. It was a cloudless May day, and even the Pool sparkled in the sunshine. The crowfoot flowers opened adoring yellow eyes to the sun, and the pale sanicle unfolded in shady places along the bank. All the flowers which grew near the Dark Pool were pale, as though starving for sunshine.

At noon Cearc-uise felt the heave of the nestlings under her breast, and clucked a motherly benediction upon them. Two had already dried into perfect puff-balls; another, squirming between his warmer brethren, was still 18 


\section{THE WATER - HEN}

damp and draggled, and even while she watched the fourth egg split and its occupant struggled into the world.

The sunshine had already left the Pool when the elder chicks grew impatient, and scrambled over the precipice of the nest's side into the water. Karruck came over at once and took charge of them. His pride in his children was monstrous. He pulled big bill-fulls of cress and starwort and called to the little ones to watch how he did it, while they paddled round him like fussy steam-tugs round a larger barque, and gaped with their yellow and geranium beaks which had not yet learned to peck. At nightfall Karruck took the chicks to the new nest, and brooded over them faithfully; but Cearc-uise kept her place upon the original nest, which now contained one newly hatched chick and a doubtful egg.

\section{VII}

Towards midnight, as Cearc-uise listened to the distant babble of the river, she grew very restless. Twice she stood up with that deliberate grace which is the moorhen's heritage among birds, and tried to coax the chick to follow her into the water, but he was too weak and could only sprawl impotently beside 


\section{WILD LIFE ON THE WING}

the remaining egg. Suddenly she looked up and met the luminous stare of the Grenogue vixen. Two of the cubs were behind, and one had so far forgotten his hunter's self-control as to whimper. His mother dared not turn on him, but her lips curled back on her fangs, and the offender sank down abashed. The nest was a dark blot against the lighter reflections of the sky. The vixen stepped on to the tree-trunk and craned her neck, but she was still three feet from her prey. She sidled forward, balancing herself awkwardly on the slipping bank, and the cubs crept a step nearer shivering with eager anticipation. Cearc-uise spread her wings over the nest, and began to cry so heart-brokenly that one cub believed that the stalking had ended satisfactorily, and rushed to the water's edge to claim his share of the meal. This flurried the vixen, and she sprang before she had quite judged her distance. Consequently, she landed just short of the nest, and striking it with her breast, tilted it over into deep water. Cearc-uise fluttered away screaming, with her tail feathers torn out, and the cubs losing all control of themselves raced up and down the bank. The vixen clambered ashore, and coughed the feathers and water out of her mouth. The cubs sobered down when she snarled at them, and trotted after her meekly. 


\section{THE WATER-HEN}

Considering that in the woods most hunting is conducted silently, there had been a vast commotion round the Pool; and the vixen, who disliked publicity upon her hunting, especially when it was unsuccessful, retired immediately, but it was a long while before Cearc-uise had done crying aloud about her plight and her escape. Then, for the first time, she heard a lonely voice piping plaintively under the alder, and when her mother-love overcame her distrust of the place and she went and searched there, she found the last chick paddling distractedly round and round, beside an addled egg.

That night the Pool held more moorhens than it had done for many months.

\section{VIII}

Karruck and Cearc-uise had accomplished what no moorhen sojourning on the Dark Pool had done for two summers - they had hatched their second brood safely; but it was another matter to rear them.

The rats sat at their burrows' mouths, and watched the moorhens feed in the crowfoot beds at dawn, as the audience sits in the boxes at the theatre to watch the play. As long as the chicks paddled in the open water, or nested 


\section{WILD LIFE ON THE WING}

upon the refuge-nest, the rats could not reach them, but the parents knew if one strayed by himself under the bank that he would never come out again.

Life is a bold adventure to the moorhens on these outlying pools. The riverside moorhen can generally baffle his enemies by putting the stream between himself and them; but on small pieces of water the hunters soon learn this trick, and harry him up and down until he is tired and bewildered and drops into their jaws. These pond-dwellers are the pioneers of their kind. At the end of every season there are deserted pools with perhaps only a few feathers scattered on the bank to tell of what had befallen the late inhabitants. But their numbers are constantly recruited from the surplus population of the riverside, where under happier conditions the mortality is less, and the risk of overcrowding greater.

At present the chicks' best safeguard was the thick crowfoot tangle which choked the Pool, for the floating stems would not bear the rat's weight and were matted too thickly for any creature to swim through them. The moorhens by constantly paddling to and fro had carved certain narrow channels in the weed; and when they went out to feed, the parents were obliged to coast down these fixed water- 


\section{THE WATER-HEN}

ways, but the chicks, who were as light as dandelion puffs, could step from one floating leaf to another without slipping down.

For the first two days of the chicks' free existence Cearc-uise never took them ashore. They.loved to paddle along in the danger zone close to the bank until she anxiously called them into the open water. There she had built a floating raft of weeds where they could rest and bask between meals, and she could relax her watchfulness a little. Thus by incessant care the family circle was kept intact for two days. On the third evening only five of the chicks answered the summons to roost, and for all her vigilance Cearc-uise had not seen the sixth disappear. She only suspected the rat.

Four of the remaining chicks were so much alike that to name them would be superfluous. Only the youngest, the runt of the family who had been untimely jostled into life by the vixen's raid, was small and slow in growth with an insatiable appetite and voice of perpetual complaint.

Meanwhile the drought increased. At first there had been heavy dews at night, but as time went on the nights were as hot as the day. The water in the Dark Pool was always warm now and smelt evilly, as more and more of the 


\section{WILD LIFE ON THE WING}

sunbaked mud round the bank was left bare. The stream was quite dried up and no more clean water entered the Pool. As the other water-holes shrank more of the wood-people came to drink at the Dark Pool. All day a constant succession of birds arrived to bathe and drink, and at night, while the old moorhens cried their vespers, the Grenogue vixen brought her cubs to cool their tongues there. The smaller the chicks were the easier it was to mind them, for they piped all the time, and if Cearc-uise missed a voice from the plaintive little symphony she turned back to look for it ; but as the blood-quills sprouted along their stumpy wings and the turkey-cock tints of their heads faded into the dull green and brown of flapperhood, so surely did their danger increase, for one or other would loiter behind the rest to pick up another morsel wholly regardless of the sinister rustling in the dropwort tuffets at the waterside. Also, they grew so fast that Cearc-uise now found it hard to cover them all at nights, and one or other who could find no room used to sleep with the father. Karruck was a good parent, but father's love is not so solicitous as mother's love and it was his fault that the second chick failed to join the muster at dawn.

The chick came to Karruck in the second raft 24 
among the weeds and cried to be covered, so he took it under his feathers and warmed it. But although Karruck was a good father he considered it his function to stand up and proclaim aloud the progress of the night, and whenever he did this the chick slipped into the water. Just before dawn, being cramped with long sitting, he went slug-hunting along the bank and left the chick by himself. The latter, cold and lonely, set out to find his mother. In the dusk the passages through the weeds were mapped out as dark paths among the mass of white crowfoot flowers, and before he had gone three yards he had lost his way hopelessly among them. Presently he heard his mother cluck, and there was a gentle lip-lap of breaking ripples. He believed that Cearc-uise was swimming ahead and paddled towards the place gladly.

But Cearc-uise was really on the other side of the Pool. It was growing light when she heard the appeal, and presently she saw the waif struggling along close to the bank. She was just going to swim across when she suddenly saw the heron, standing lank and silent on the brink. His bill lay on his breast, but she knew that all the while his eye was following the unconscious chick, who after his custom was paddling close inshore. She saw 


\section{WILD LIFE ON THE WING}

that in another moment he would be within range of the heron's thrust, and ran across the weed-bed calling in the hope that he would hear in time. He turned, and instantly the deadly bill darted at him. There was a gurgle and a splash, and then the channel in front of the heron was empty.

The stream had no more voice to tell the woods that the Pool had seen the end of another moorhen, but Karruck and Cearc-uise related the sad story over and over again; and even after the murderer had departed, their sorrowful voices could be heard faintly as far away as the river bank.

\section{IX}

The next day, in spite of their fears, the parents took the four remaining chicks ashore to feed. Normally the Pool had shallows round the edge, and a deeper hole in the middle; but now the water was so low that all the shallows were dry and covered with a spongy mass of whitened weed and slime where even the mint plants wilted, while all that was left of the Dark Pool was a pitiful travesty ten feet square, warm and dirty. Therefore in the afternoon they went a little way up the bed of the stream, which was now only a disconnected series of muddy puddles. 26 


\section{THE WATER-HEN}

Cearc-uise found that if it had been difficult to keep the chicks together in the water, it was infinitely harder on land; for each ran his own way after slug or fly, and as the ivy-leaves which carpeted the ground could each cover a chick, she was constantly losing one or other of them. However, she marshalled them safely up the dried watercourse where she had first met Karruck, but when they came to the clearing where the path to Ballin crosses the stream, the chicks ran riot altogether. The place was a jungle of dock-leaves and nettles, and swarmed with flies which the chicks chased ardently, and although Cearc-uise could hear them calling all round her, the tangle was too thick for her to see them. She found the youngest crying by himself because he could not cross a fallen branch which lay in his way. She coaxed him to follow her round it, and then left him while she searched for his brothers. After a time she found two of them squabbling over a worm and conducted them back, but by this time the first had disappeared. Just then she heard a regular thud-thud approaching quickly. She ran out of the nettle-bed, and came face to face with the man. There is a time to fight and a time to fly. Cearc-uise knew that it was

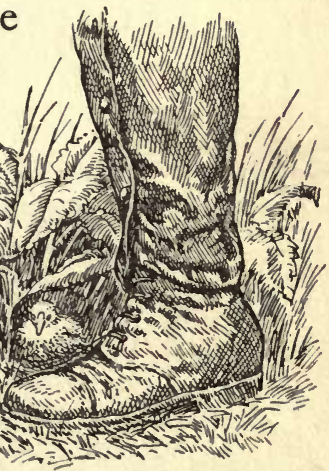




\section{WILD LIFE ON THE WING}

occasion for the latter. Her children were well-schooled. Nevertheless, as she hastily took covert she called out her directions anxiously: "Rek-rek-Be still, be still." The chicks obeyed her implicitly, and even though the trampling of the man's feet shook the earth within an inch of them, they lay quite quietly, only calling out softly for further instructions.

When the man had passed on, and the wood was still again, Cearc-uise ran back and called up the chicks. The first crept out of a hollow tree-stump; the second, very frightened, squeezed out between two dock stems; the youngest, being full of worms when the alarm was given, had crouched down where he was, but luckily his sooty coat had escaped detection. He came out with dirt on his jacket, and complained loudly as his custom was. As for the fourth chick, the man's heavy boot had crushed down the nettles in a double swathe, and for all her calling and searching, Cearc-uise only led three of her brood back to the Pool.

\section{$\mathrm{X}$}

That evening she covered a meagre nestful. The night was almost as hot as the day, and the starshine seemed to parch the earth as 28 


\section{THE WATER-HEN}

remorselessly as the sun. The oily surface of the Pool was unruffled by any wind. But the river, though it had little enough water flowing over its pebbles, babbled so loudly that the moorhens could hear it across the meadow, and the sound of fresh running water was enticing after

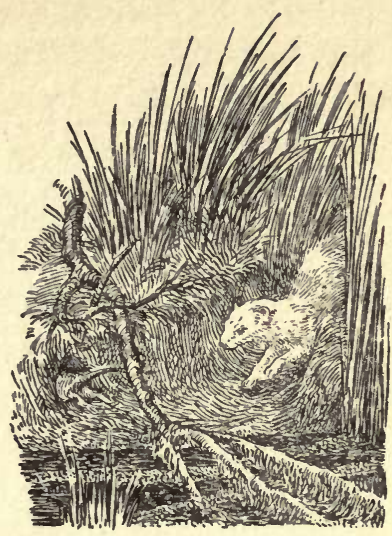
the hot, stagnant Pool. In another week the little ones might be strong enough to attempt the journey over the intervening meadows, but at present Cearc-uise thought that they were too small to force their way through the long grass; and although the old nest had long ago been left high and dry, there was still the floating refuge-nest in the middle of what had been the Pool, which afforded them some measure of safety.

All night long footsteps came and went through the bushes. A stoat visited the rats' burrow, and though, as a rule, the inmates escaped easily through their back-doors, which opened under water, yet now these short cuts were all high and dry, and the stoat had good hunting. But just before dawn the stoat himself retreated 


\section{WILD LIFE ON THE WING}

quietly before a heavy but soft footfall which he heard approaching down the bed of the stream. It was long since the Pool had been honoured by a visit from such a hunter. The youngest chick, skulking among the watercresses, thought at first that it was the fox, but the stranger plunged into the water gleefully and half swam, half waded along the edge. All previous danger had threatened from the bank ... the chick did not understand this new manœuvre, and scuttled inshore. Cearcuise suddenly broke out with piteous cries. She was of the river, and knew who it was that hunted after this fashion.

One chick lost his wits and, instead of lying still, paddled from one reed tussock to another. Instantly the otter leaped like a salmon, and caught him before he could dive. The splash set the water breaking and splashing up the mud banks. The otter had only paused to drink at the Pool on his way from a distant stream to the river. Of course, one chick was nothing to his appetite, but he was full-fed already, and now merely hunted for sport.

The moorhen-kind have been made free of the air-, earth-, and waterways. The airways are a matter of wings, the earthways are a matter of legs, but the waterways depend almost entirely upon lungs. The runt-chick dived as 


\section{THE WATER-HEN}

neatly as a grebe into the underwater world, full of cool indefinitudes and amber lights, and instantly the otter's rush washed him into a tangle of weeds. He thrust up his bill under a crowfoot leaf, and caught one shuddering, delicious breath of air before his pursuer saw the bubbles and snapped at them a second too late. The chick dived down until he could see the caddis grubs crawling about on the bottom beneath him. Then the mud cloud stirred up by the otter's passage enveloped him, and he struggled through it to the surface gasping. Three times he dived and came up again, and the third time he was close to the bank with a welcome rat-hole in front of him. He crept inside and cowered out of sight, as the waves created by the otter's successful hunting broke on the floor at his feet.

Half an hour afterwards, when the Pool was still again, his mother swam under the brambles and called him. He came out, cheeping sadly, and she took him away quietly to covert. All day they hid among the watercresses. The reflections of the ripples threw sinister shimmers upon the leaves, which the otter's heavy paws had beaten flat. They heard Karruck call once or twice as he skulked in the bushes, but the runt-chick had the dusky 


\section{WILD LIFE ON THE WING}

canopy of his mother's feathers all to himself, for his brother never came to share it with him.

The heat grew more stifling as the day went on, but towards evening, though the wind did not rise, a great bank of clouds piled up in the west, and the sky below them was an angry brown and purple like a bruise. Twilight drew on earlier than usual because the sky was so dark, and not a breath of air stirred the woods. The birds sang half-heartedly, and dropped into silence one by one. The only sound was the roar of the river in the distance. Cearc-uise and her last chick took their supper hurriedly. The runt ate voraciously, as he always did, but his mother scarcely touched anything ; and he had scarcely dozed under her wing for half an hour before she stood up and tumbled him out. It was quite dark by now, but the air was hotter than ever, and a warm, bad stench arose from the Pool. Cearc-uise tripped softly into the bushes and called to the chick to follow her. At first he took her jerking white tail-coverts for a pilot and followed her by sight, but before they had gone half a dozen yards he could see no longer and was obliged to trail her by sound. The rustle of their footsteps was the only sound which broke the silence. She was on the look$3^{2}$ 
out for enemies on their trail, but it seemed as though they were the only things which stirred abroad that night. The woods were still, as if lying in expectation. Cearc-uise, who had lived in and about water for twelve months, recognized the feel of it in the air, and knew that heavy rain was coming before morning. They crossed the narrow strip of wood which lay between the Pool and the open meadow. There was a loosely built stone wall here. The chick saw his mother's white tail-feathers suddenly disappear as she fluttered to the top, and he tried to follow her, but his claws slipped on the stones and he slithered back, cheeping helplessly. This was the first serious set-back to their progress, and the woodside was not a safe place to linger in ; nevertheless, as a moorhen

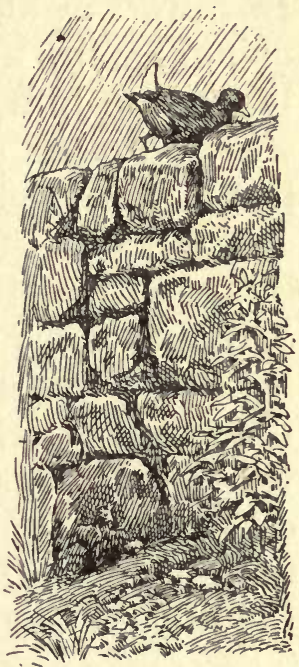
likes to talk over most situations at length, Cearc-uise balanced herself upon the top of the wall and began to call and reason with the chick more loudly than was at all wise. At first he obeyed, and tried frantically to climb up the smooth stone, but when he found that 


\section{WILD LIFE ON THE WING}

it was of no use he crouched under the wall and to all her coaxing and scolding he only answered with a sullen chirp.

At this juncture came the first clap of thunder. All the moorhens on the distant river-bank shrieked together, for nothing upsets them so much as a loud and sudden noise. Cearc-uise flew off the wall, screaming hysterically. Luckily she alighted in the wood, and the chick, seeing her white tail-coverts twinkling in front of him, ran after them thankfully. It was fortunate that he did so, for his mother had forgotten all about him for the time being, and did not recollect his existence until she stopped from sheer exhaustion, and heard him crying despairingly in the darkness. However, her flight had been opportune in one way, for she found herself opposite a hole in the wall where a loosened stone had slipped out; and on running inside with the chick behind her, she unexpectedly found herself in the field on the other side.

The woods were quite still again, waiting for the next thunder-peal, and the open sky was so awful to Cearc-uise that she would have turned and run back through the hole, only that on the other side she suddenly heard a noise, softer, but quite as terrible as the thunderclap-the patter of feet. The hunter, who34 


\section{THE WATER-HEN}

ever he was, snuffled on their trail, and she knew that if it were Tufoigin the Stoat they would have no chance of escape, but it might be a fox, and if so the hole would be too small for him to follow. The chick rustled the grass close at hand, and she clucked to him that he should lie still. She crouched down with a beating heart as the hunter stopped and snuffled at the wall. He gave a whimper, and a couple of impatient scrapes at the stones, but the thunder boomed overhead again, and bethinking himself of the rain to come he trotted on.

When the patter of his footsteps had died away, Cearc-uise called to her chick and set out steadily towards the river, guided, perhaps, by that strange instinct which leads the moorhen so far afield through the darkness to new waters. But not thus had she crossed the meadows on the night when she had first come to the Dark Pool two months before, and all that night her instinct of self-preservation was at war with her mother-love, but in the end the latter won, and she regulated her pace and path to the feeble powers of the chick.

A flash of lightning lit up the grass round them, and on its heels came a

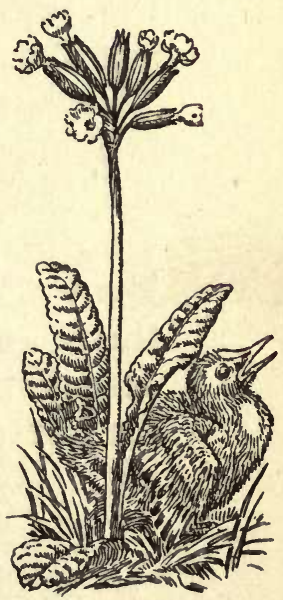




\section{WILD LIFE ON THE WING}

louder clap of thunder. This time Cearc-uise did not shriek, but only ran the faster. She hurried on so far ahead that she lost the chick altogether, and was obliged to return for him. $\mathrm{He}$ sat crying under a cowslip, because he had never walked so far in his life and was already tired. This would never do. They were not yet half-way to the river. Cearc-uise roused him at once and made him follow her. By the lightning they saw the grasses stand out limply against the bluish sky. Beside the babble of the river, which seemed as though chuckling at the thought of the coming freshet, the only sound between the thunderrolls was the voice of the moorhen's cousin, Garra-gurt the Corncrake, who rasped his name aloud, unmoved by the tumult overhead. He glided before them as they went, and though his voice sounded now to the left and then to the right, they felt the grassblades close up just ahead of them as he passed.

The first rain fell before they came to the first hedge. It fell in drops as big as sloes on to the baked ground; and the grassblades, overweighted, drooped this way and that, until Cearc-uise could scarcely force a way through them, and the chick would have given up in despair if she had not returned to help him. At last they came to the hedge, and already a 36 


\section{THE WATER-HEN}

stream three inches deep flowed through the ditch on the nearer side, for the earth was so parched that at first all the rain ran off it as from brass. The chick listened to the sound of running water thankfully, for he believed that this was to be the end of their journey, but his mother ran down the fence and he dared not remain behind. It was too dark even to see her white tail-coverts, but at her "kek" of encouragement he plunged boldly into the coldest water he had ever known, and, struggling across, found himself in the next field.

The thunder was dying away in the distance, though the lightning flashed as vividly as ever; but the rain still fell with a soft rushing like the heaving of enormous sighs, and even Garragurt the Corncrake was silent under the downpour. The long grass was beaten down in dank swathes, and new sweet smells were beginning to rise from it. The cattle stood in a group by the hedge with the water running from their sides. They did not see the moorhens as they passed. From the wood behind came the sound of water running down old dusty channels to which it had long been a stranger, but Cearc-uise never made any mistake. The Dark Pool might be filled to the brim once more, but she would not return thither. She kept straight on to the river, 


\section{WILD LIFE ON THE WING}

where she had been bred; for the sound of it flowing over its pebbles was nearer and more jubilant than ever.

In this field the grass was eaten more closely by the cattle, and they made better progress, especially along the path where their foot trail ran for fifty yards - the broad arrow of Cearcuise with the smaller point of the little one superimposed upon it. The clouds began to draw away to the east in the wake of the thunder, and the rain fell less heavily. For the first time for many days the air was cool. A lark rose up from the saturated meadow carolling rapturously, and as the western skies cleared, a little crescent moon dipped to its setting. The chick was wet through and very weary, but he struggled on bravely enough, for it was now light enough for him to see his mother in front of him. She did not walk with her jaunty carriage, but crouched low like a landrail lest some enemy should chance to see her head moving about the grass.

Suddenly a moorhen screamed close at hand. At the sound Cearc-uise began to run swiftly, and the chick followed as best he might, for the wet grasses swung back and hit him in the face. He heard a splash-then a wholly rapturous "kek-keking." He thrust after her through a tangle of comfrey and vetches, and $3^{8}$ 


\section{THE WATER-HEN}

suddenly found himself on the river-bank. His heritage was before him - the wide shallows, the still pools and creeks with their strong cool river smells. To left and right lay the flowering coverts that every riverside moorhen knows and loves-bittersweet, willowherb, and the bluebell flower. Against the setting moon the weir stood up like a wall of roaring water dappled with shifting silver lights, and at its foot, among the eddies, Cearcuise stood on a shaggy moss-stone and called to him to take seizin of the place. The air was full of the music of running water and the smell of the rain on the lush-grass. . . . The chick took a header off the bank, and the river received him gladly. 


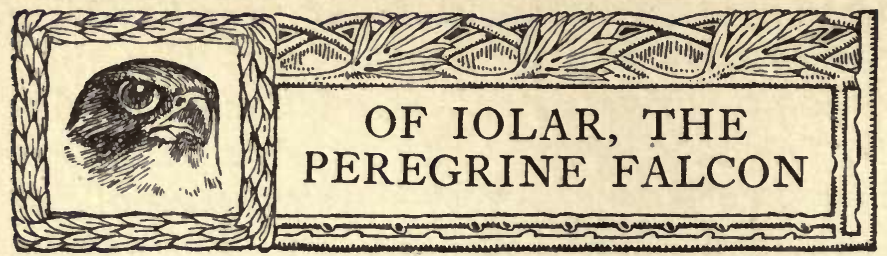

\section{I}

HE took sanctuary one November dawn, when the sky was a purple and primrose setting for the morning star. A fortnight long the waxing of the moon had fostered storms; now the earth lay saturate, studded with pools of flood-water, and there was no more wind. Yet it was an inhospitable land this to which he had strayed. Here were no mountains, neither moor nor cliff. It was a level country, fully populated, full of prosperity, where a freelance such as he might meet with nothing but the thunder and leaden spit of Man's gun.

Whence he came, storm-beaten and benighted, is not known. Man had set his mark on him already-three crimson gouts upon his flank had taught him the fear of ambushes. North and south were alike to him; east and west meant the coming of day and passing of night. $\mathrm{He}$ drifted eastwards with the wind. The 40 


\section{THE PEREGRINE FALCON}

smoke wisps from men's chimneys stood together as closely as the trees which bordered men's shaven fields. From source to estuary the river flowed through a country without a hill : smooth from horizon to horizon.

The great spire towered above the city in the plain, its grey front-stout as the crags along the Atlantic seaboard-black against the light. Only the golden cross which barbed the steeple caught the sunrise fire and outvied the morning star. Smoke curled from the houses round about, but as yet the city lay at peace. Storm-beaten and weary, in an unknown and hostile world, the peregrine falcon took sanctuary.

St. John's Church stood in the middle of Durrowmore town, built on a mound which lifted it to the level of the roofs of the surrounding houses-fifty feet nearer heaven. The mound was fenced with spiked iron palings, as though to fend off the encroaching buildings, and squalid children squabbled and clamoured in the street, and clambered along the railings to pick the dusty laurustinus flowers between the bars.

Every day the people passed in and out through the silently swinging doors of the church, and on Sundays and holidays they 


\section{WILD LIFE ON THE WING}

went in scores because it was God's house. The west front of the tower carried a great dial, and every fifteen minutes, day or night, the church clock boomed the passage of the hour to the town. East of the tower the broad grey roofs of the body of the churchnave, transepts, and Lady Chapel, lay cruciform, and their leads, pinnacles, and gables were unvisited by man from month to month. The people of the church roofs were a people apart. They lived under the arms of the great gold cross, and men, busied with their own joys and griefs and labours in the smoky streets below, seldom molested them. There were the pigeons-blue, white and pied - who took their flights morning and evening over the town. They bred in the deeper crevices of the walls and among the dusty timbers above the belfry. The jackdaws also lived in the tower, a merry, social company. They fed on the leavings of the middens in the town below, and roosted, huddled together, under gables and buttresses. Then there were the starlings, cheerful gossips who came and went with the shifting of the seasons, fizzling and whistling in the sunshine, squabbling in the rain. The swifts were the aristocracy of the tower. They came in the warm weather, and could put a girdle round the spire thrice a 


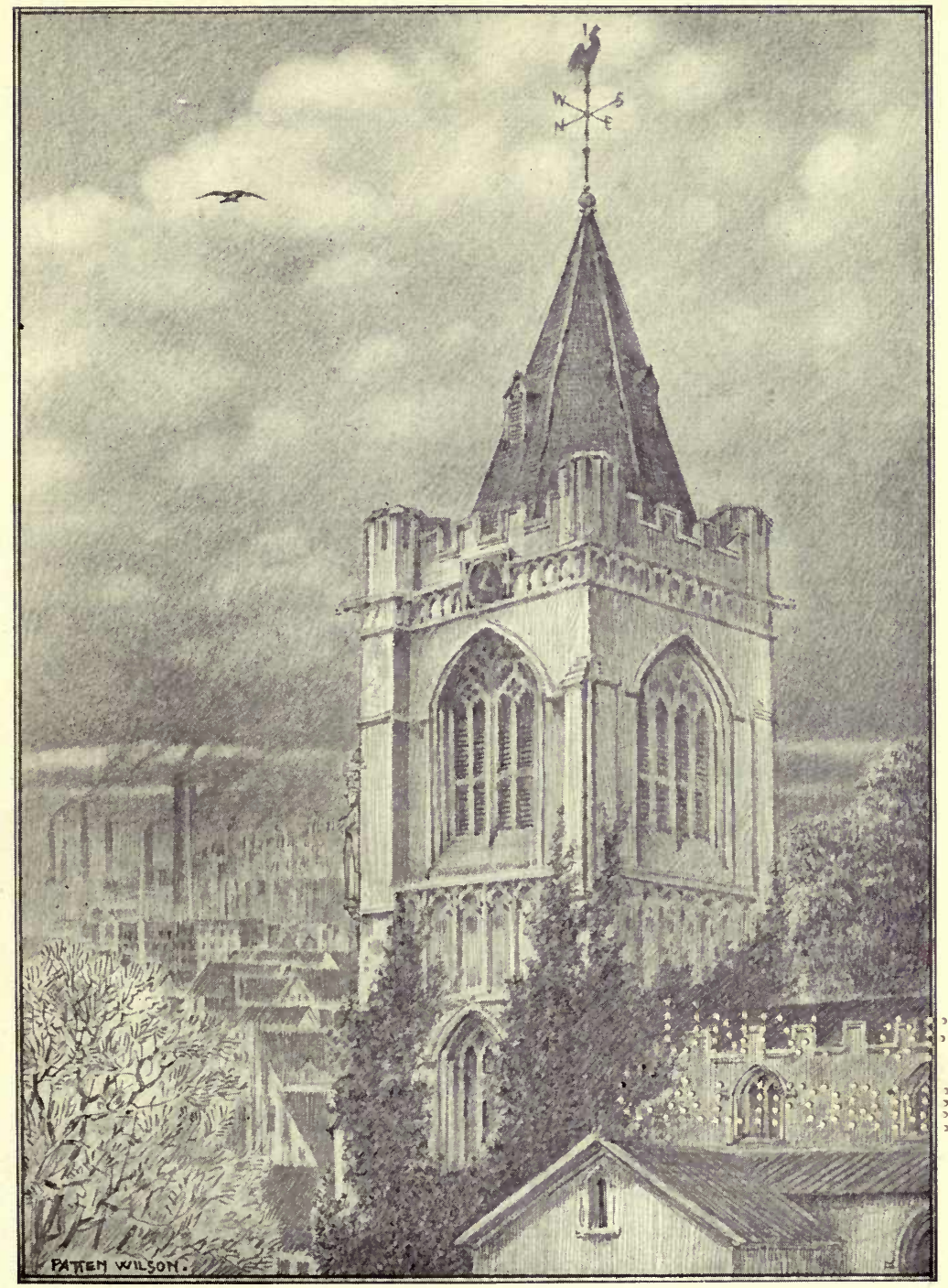

IOLAR TAKES SANCTUARY 



\section{THE PEREGRINE FALCON}

minute from dawn to dusk, screaming deviling-like as they chased one another over the roofs. Lastly, there were the bats, small, quiet people, who shunned the light and hung polls downwards in musty-smelling companies until sunset. Such were the inhabitants of the tower when the peregrine came to dwell among them-a buccaneer among merchantmen.

Cudóg the Jackdaw saw him first. Cudóg was taking a hurried bath in a gutter on the chancel roof. There was a click of folding wings, and the daw looked up with the water-drops still shining
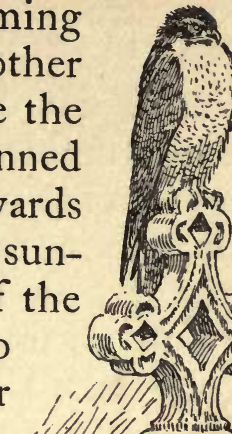


\section{WILD LIFE ON THE WING}

come from? Who was it? Where! How! Why!

Haro! Haro! Haro! Let them all go seek it ! They tumbled from the tower like a mob of boys racing out of school, and skimmed headlong in a merry pell-mell rout, chasing one another, dodging, doubling, feigning fear: "You go find it-mind it doesn't catch you ! Yaha-yaha!"

So they came to the great west front, where St. John in his niche gazed benignly out over the level country, with his psalter held to his bosom and a sparrow's nest tucked into the deep angle of his arm. Here the rabble swung upwards, gabbling and skylarking, forgetting their original quest in an aerial catch-as-catchcan, and so came upon him.

Then the game changed to a mirthful panic, as when a band of children playing hide-and-seek spy him who hides, and run away shrieking. With a swoof of wings the peregrine dived after them, missed the hindermost by a wing's breadth, and swung back to the stone niche of St. John, where he rested, his claws clutching the saint's chiselled ringlets. $\mathrm{He}$ was miserable, weary, hungry, a stranger in the strangest land which he had ever seen, too bewildered to pursue such strong-flighted quarry farther. 


\section{THE PEREGRINE FALCON}

Meanwhile the daws mustered upon the nave and, cackling and gabbling, threshed the matter out. A strange bird-a very strange bird. Let them find out all about him ! Let him show his credentials. One, bolder than the rest, dropped to the sill of a belfry window and peeped down. "What-ho?" he challenged interrogatively. The peregrine did not stir. Bolder, the inquisitive one dropped again, sheering off from the niche. His fellows took courage from his hardihood, and wheeled round with jeer and foolish jest, daring him to strike. The peregrine sat hunched, with closed eyes: he was weak with travel, and his vitality had dripped away from his flank before the feathers, clotting on the wound, had staunched the flow of blood. $\mathrm{He}$ wanted a full meal and peace for a few hours before he could face the world again. Sullenly he took wing and soared up, tilting now this van, now that, to win the lift of the wind. After him came the daws, daring one another to buffet him. They drew level with the slit-window of the spire. It was a dark, dusty harbourage, but his persecutors would not dare to follow him inside. He took refuge in it thankfully, and the jackdaws returned baffled to their fastnesses on the roof-tops. 


\section{WILD LIFE ON THE WING}

\section{II}

For three days the peregrine nursed his wounded side, husbanding his slowly returning strength among the dim-cobwebbed timbers of the spire. The winter sunshine poured in through the loopholes on the south face, and was succeeded by moonshine, brightened by frost. Great bloated spiders lived among the beams, and, undisturbed, spun their webs, thick as a silkworm's cocoon, upon the relics of their predecessor's industry. The tower might not be old as men reckon time; by spiders' counting it had stood age-long. Big furry moths sometimes slept pressed against the walls, and the place was musty with the sickening odour of bats. Except when the clanging boom of the great clock made the spire ring, there was silence in the tower-a silence so deep that it seemed as though not a spider could tread without being overheard. But all the day and night through, even when the air in the streets below seemed still, the wind sang round the tower, in and out of the dusty windows and round the great culminating cross, until its sibilant voice seemed to be the voice of the silence.

At first the clangor of clock and bell drove the 46 
THE PEREGRINE FALCON

peregrine from his perch out through the loopholes into the thin winter sunshine, but by the end of the second day he started less at the crash and whirr which seemed to make the very cobwebs shake. Whenever he sought the outer air, the jackdaws saw him. There were generally three or four gossiping just below him on the south parapet of the tower, and the sight of him, fugitive, bemused and dazzled by the sudden noise and sunshine, was the signal for the whole tribe to dash after him over the nave roof to the Lady Chapel and back, until he took refuge in the spire again. When he ventured out to sun himself on the sill of the loop-hole or drink from the gutters, they swaggered round him, bullying and becking, with cunning sidelong glances. At intervals throughout the day, as the falcon sat hunched out of sight, he heard the interrogative "Yaha?" and Cudóg's black wings eclipsed the light as he sidled on the window-ledge. But the peregrine refused to be tempted. In the cold dawn of the second day he struck an unwary starling on the leads, and the meal put new heart in him. Next morning he caught a sparrow. The daws skylarking over the roofs merely saw the flick of his wing as he slipped over the parapet with weighted claws; they did not recognize a danger signal in the scattered 


\section{WILD LIFE ON THE WING}

feathers. Then the peregrine sat torpid. Sparrows and stares were mean game for such as he. Next day he would do better.

It was a damp chilly morning, and although no rain fell the roofs were wet. The peregrine woke when the daylight sent a faint shaft across his perch, and stretching claw and wing flapped to the window-sill. With his strength his hunger had returned. The smoke rose straight up into the damp air from a hundred chimneys. From his lofty perch he looked out over a mile of grey roofs and lesser spires to where the river ran between dingy wharves under the masts of the ships. In the narrow streets slow carts crawled and men lounged and shouted. They looked very small and slow, and their voices sounded puny and far off. The peregrine circled up until he rose level with the great cross at the apex of the spire. Its gilded arms swung north and south as the wind blew, that seafaring men by the wharves on the river might look to St. John to tell them the weather. The peregrine who had first seen the sky from a crag five hundred feet above the Atlantic swell was at his ease at last. Far below him on the transept roof the daws sat in a row. They had not seen him: how should they look for danger from the sky? Then a latecomer swung leisurely from the belfry window $4^{8}$ 
THE PEREGRINE FALCON

to join the council, and the falcon dropped like a plummet. The quarry heard the rustle of his wings, but before she could, sheer aside he struck her across the loins. She fell headlong to the transept roof dragging him after her. The jackdaw parliament broke up in dismay. What thing was this, that this butt of theirs, stupid as an owl, a fellow-lurker with bats, should turn the tables thus? Preposterous, absurd! They argued and cursed, halfterrified half-curious, while the falcon on the transept gable enjoyed the first full gorge which he had had for a week, and prodigally dropped what he could not devour. He preened himself and polished his empurpled bill against the stone, then he leisurely took wing, and the daws had a glimpse of keen eyes and talons to which a dusky feather still adhered. This was no silly kestrel to be mobbed and mocked. The jeer was cut short. Silently and with flick of wings the whole band dived over the edge of the parapet. But the falcon had before him some- 


\section{WILD LIFE ON THE WING}

thing more congenial than revenge upon jackdaws. He settled himself down to enjoy the sleep of the full-fed and contented. And all that afternoon no daw came to squabble and mock on the face of the tower lest judgment should descend upon him also.

It was growing dark when the peregrine came down; the great clock boomed four. In the gravel close far below, Seumas Skerritt, the sexton, with the keys of the sacristy door in his hand, looked up, and against the sky had a glimpse of a buoyant silhouette. He was ordinarily a silent man-Seumas Skerritt-but as he watched the bird circle upwards he swore by this and that and good mankind that an eagle-Iolar-had come to the tower.

\section{III}

Henceforward in this man-made cliff the peregrine lived well. But these pigeons of St. John, on whom he chiefly preyed, were soft and slow-flighted compared to those rock-bred birds of his native crags, whose wings, like his own, were toughened by a hundred struggles with the western gales, and he struck them down easily. Before the moon had waned, their ranks were thinned. The sluggards of the flock were gone, and the stray feathers50 


\section{THE PEREGRINE FALCON}

bronze and grey-which the wind blew about the roofs testified whither. When the survivors went to feed on the car-rank down below they were so tame that they would scarcely flutter from the horses' feet ; but now, when on the tower, they became so wild that a jackdaw flapping overhead was sufficient to drive them down in panic to the level of the chimney cowls. There the falcon dared not pursue them, for men leaned out of their windows and pointed, calling to one another to look at Iolar, the eagle of St. John's.

Now and then he killed a daw, but daws were tough and rank-flavoured compared to pigeons, and, moreover, they were strong-winged and cautious, conducting their frolics and councils as far from him as possible. In fine weather he perched on the south parapet of the tower to enjoy the wintry sunshine, and although it had formerly been the favourite resort of the daws they dared not dispute his possession of it. The sparrows, the little browneens, who nested among the deep stone carving of the western front, minded him least of all the people in the tower, perhaps because he busied himself with them very little. Falcons flew for higher quarry.

In stormy weather Iolar sought the refuge of the spire, though even there was little enough 


\section{WILD LIFE ON THE WING}

shelter to be had when the sea-wind whimpered

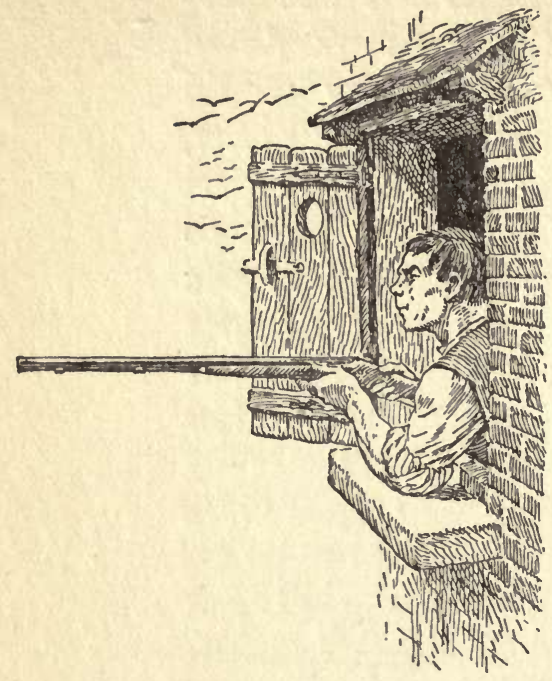
through the loopholes and blew the cobwebs to and fro. At such times the jackdaws and pigeons fed in the streets and gardens of the town, and Iolar went hungry. Then he was driven to forage farther afield, and that was how he came to recognize the worth of sanctuary, for beyond the shadow of the steeple he was an outlaw - coveted by many and hated by all. $\mathrm{He}$ learned the thunder of gunshots and the whistle of lead: he knew what it was to hunt over smooth, cultivated country for half a day, nor dare to stoop at bird or beast lest some enemy should be lurking in the ambush of tree or thicket. But gradually he understood that there was a zone of safety round the stained-glass windows of St. John. Many a time he turned thither as to his only refuge in a hostile land. No gun was ever pointed at him as he perched at ease upon the glittering vane, and, like the daws and pigeons, he realized 52 


\section{THE PEREGRINE FALCON}

that this was holy ground where even the malevolence of man was checked.

But it chanced that there was a warehouse by the river, owned by one Rafferty, who, in an upper storey of his granaries, kept many pigeons - strange and rare breeds such as Iolar had never seen before, but tame and easy killing. When times were hard, Iolar sometimes stooped at parties of these pigeons which flew near the tower, and at length news of the havoc he wrought among them came to the ears of Rafferty himself. He lay in wait, gun in hand, at an upper window, but Iolar, that cunning fowler, never came within shot, but struck a prize tumbler before its owner's eyes and retired unharmed to sanctuary.

Then came a storm from the nor'-west, and fleecy snowdrifts were piled up on the windowsills. The peregrine hawked round the tower, but the wind drove the snow along so thickly and so fast that from the roof of the Lady Chapel one could scarcely see the great bulk of the spire. The starlings betook themselves to where the wind nipped less keenly: the pigeons fed in the roadways, and the sparrows took refuge among the chimney cowls. Iolar was alone in the spire. Not even a bat stirred; the spiders slept. The gutters were choked with smut-grimed sludge, and icicles 


\section{WILD LIFE ON THE WING}

banked the lips of the spouts. Iolar grew fierce with hunger. Each straggling party of pigeons who ventured near the place dashed away with the whistle of his wings behind them. But, towards evening, the sky cleared with promise of frost. A band of plover flapped southwards, and the peregrine's eyes followed them hungrily; but they passed high above his head, and he huddled down again doggedly to watch. In an hour the light would be gone, and he would have to spend a third night fasting. Suddenly, against the pink sky to the north, he saw a rapidly moving speck. It was a strange pigeon. It was beneath him before it saw its danger, and, as it swerved aside, the red sunset light awakened an answering reflection on its neck. So much Iolar saw, and then he swooped and struck. They parachuted down. The pigeon was a strong bird, and nerved by terror strained ahead to reach the cote by the river. For a brief space they struggled in mid-air, then, under its captor's grip, the pigeon ceased to flutter, and Iolar bore it down to the transept roof. $\mathrm{He}$ feasted at his leisure, and when the stars came out there was little left but the quill feathers and the larger bones. But one red foot which slid down the gable and lay on the snow in the gutter wore a metal anklet with 


\section{THE PEREGRINE FALCON}

a number. B/D25 would never return to Rafferty's granaries.

That meal saved Iolar. He kept within the tower for a day and a night, and when he came out to forage again the frost had broken and the snow melted. With the thaw the daws and pigeons came back to the tower, and the time of starvation was over; but late one afternoon, as he preened himself on a pinnacle of the northern parapet, the little door which opened on to the leads from the belfry creaked on its unaccustomed hinges, and a man stepped on to the roof. Iolar dashed up, calling shrilly. Hitherto he had never seen a man up there. In the open country or in the town below he would have forthwith put a mile between himself and man, but was not this sanctuary?

The man moved across the slippery roofs, noting the relics of previous feasts. Among the vulgar jetsam of the daws, culled from the town's pig troughs, were bronze and blue feathers and whitening bones. That was no daw's work. The man picked up a feather here and there, and lastly stooped to pick up the last link in the evidence against Iolar-the little metal ring which had encircled the foot of $\mathrm{B} / \mathrm{D}_{2} 5$.

Seumas Skerritt put the ring into his pocket. In his imagination it clinked against a coin- 


\section{WILD LIFE ON THE WING}

the price of the betrayal of sanctuary. Iolar, from the vane, watched him, half-warily halfcontemptuously. Man he knew as a power who let loose lead and flame at sight; but already he understood that under the gold cross the thunder of the gun was never heard, and what else was to be feared? He had yet to learn that man himself once trusted and was betrayed, and that since then he holds no sanctuary sacred.

\section{IV}

Two days later Iolar came out at dawn. The edges of the sunrise clouds were hard and golden; the wind blew freshly off the sea. A flight of teal, travelling northwards over the city, predicted hard weather. Iolar looked down upon the roof of the tower. Three or four jackdaws, perched on the parapet, were eagerly discussing some untoward happening. The daws were always full of noisy talk, and Iolar seldom flew at them now unless he could not obtain a pigeon; nevertheless, this time he looked more closely, for they were evidently baiting something in the angle of the parapet. At that distance it was something which looked like a stone. His curiosity whetted, Iolar swooped majestically from the spire's level, and 56 


\section{THE PEREGRINE FALCON}

the jackdaws scattered at his coming. But it was not a stone. He slanted across the roof and stared. In the angle of the wall hung a small cage, and inside, barred from the free sky and sun, fluttered a goldfinch. Iolar sheered off. There was something uncanny about that bird. How came it there and why? $\mathrm{He}$ perched in the embrasure of a spirelight and considered this strange thing. The goldfinch chirruped and beat against the bars. The morning air had whetted Iolar's appetite, and this seemed an easy prey. He pitched before the cage, and the bird fluttered piteously. No danger here-the man had gone. Iolar rose again and swooped with claws extended. Even as he alighted on the cage the steel jaws of the rabbit trap gaped and snapped below his tarsal joint. He forged forward, dragging the gin after him, and under his weight the cage slipped from the nail which secured it to the parapet and fell to the roof of the tower. Iolar crashed down to the length of the chain, and hung breathless by his feet, with all the height to the churchyard-close below him. For a minute he gasped, bewildered at the inversion of his world, then as his senses reeled back to him he understood. The cunning live bait to lure him; the gin ready set above the cage, its chain made fast to a staple driven 


\section{WILD LIFE ON THE WING}

between the stones. He whirled up his wings and beat his breast bare against the wall. He threw himself out, and the weight of the iron dragged him back. He found no purchase for his prisoned feet, for he who had set the trap had done his work well. The steel jaws were rubber fanged; contrived to grip, not to crush. They numbed but did not cut. So he struggled, while the winter sun rose level with the transept roofs, and the jackdaws came crowding to the spectacle, gabbling amazedly to see their late overlord in such a plight. The belfry clock struck four quarters, then tolled the hour, and Seumas Skerritt from the street below looked up and saw something flutter feebly at the corner of the parapet overhead. A few minutes later and Iolar heard the tramp of feet on the stair, and knew that his captor was coming. He threw himself forward, screaming and fighting, and Skerritt hurried up eagerly when he saw that his captive was still alive. The staple which held the gin to the wall was driven in to the head, but even so the mortar which held it had been loosened from the stone. Something slipped : in his panic Iolar heeded not whether it were his bond or his sinews. The man was stretching over the edge to clutch him. Iolar struck back at the hand. At that moment it was $5^{8}$ 


\section{THE PEREGRINE FALCON}

more hatred than fear which nerved him. Had he been free, and with the power, he would have flown at the traitor and torn him limb from limb, as relentlessly as he tore the silly starlings on the gables, but as it was anger did what fear could not. Another wrench and the staple fell jingling from the wall.

With the blood surging in his brain Iolar fell headlong. The roof of the nave rushed up to meet him. He crashed upon the slates, and slithered helplessly down the steep slope until he was brought up with a jerk by the iron frame of a skylight which gave upon the body of the church.

Seumas Skerritt, leaning from the battlements, marked where he fell, and ran down the tower stairs to the little door which opened upon the leads. A man could walk easily in the angle made by the slope of the nave roof on the one hand and the north aisle on the other. $\mathrm{He}$ edged his way along, steadying himself against the slates, until he came opposite the skylight and could reach up to the chain. But at the nearness of his hand, and the grinning triumph of his face, Iolar, full of fear and repulsion, took wing, and surmounting the sharp ridge of the nave, slipped out of sight into the angle of the south aisle on the other side. 


\section{WILD LIFE ON THE WING}

Seumas Skerritt was chagrined, for with the hawk he saw five shillings disappear, but he consoled himself by reflecting that the capture was only deferred. Meanwhile it was growing late, and, as he did not wish the people in the market to see him climbing on the church roof, he withdrew, locking the door behind him.

When the roofs were left in peace at last, Iolar began to comprehend his plight. The rubber which numbed the fangs of the trap prevented the jaws from closing right home. Hence his legs were merely gripped, not crushed. Indeed, so carefully had Skerritt arranged the gin that had but one foot been trapped the prisoner might almost have pulled the limb from the jaws; but as it was, both feet were held, and, flutter as he would, he could but drag the trap after him over the roofs and beat his heart out over the bare ridges and valleys of slate. At first he felt more wrath than fear. With whirring wings he fought the iron. Thus had he once fought with a great gull whom, in a rash moment, he had struck, and for his honour dared not let go. $\mathrm{He}$ raged up and down the gutter, wrenching his legs cruelly, bruising himself against the slates. The chain jangled merrily behind him as if in mockery. He thought that it was the man's step behind, and wheeling round, struck at it with his 60 


\section{THE PEREGRINE FALCON}

beak, until he split the sharp horn edges. Then he grew tired and sullen: huddled down in an angle of the wall. The daws came to the chancel roof to look at him with awe. So once had he sat until they mocked him, and then, all unexpectedly, had pounced. Therefore they kept their distance.

By nightfall the rusty trap was polished bright. Had he but had one leg free he would have tugged and whirled until the captive limb were twisted off; but as it was, with both talons impotent, even this poor freedom was denied. He fell upon the gutta-percha padding, and chiselled at it feverishly until he struck his own flesh. But when the softer rubber was gone, the jaws closed slowly and bit into his leg. Then it seemed to him that this clog must be part of his own body-some sudden and awful deformity; he shrank back into torpor, loathing himself.

Towards evening the daws went to their accustomed roofs; the pigeons and starlings sought their crannies and crevices in the tower. Iolar took wing laboriously, and rose with infinite struggle to the level of the belfry; then beating like a kestrel against the wind the weight of the gin dragged him back again. He struggled until he could do no more. He even tried to perch upon the sloping ledge of the belfry 


\section{WILD LIFE ON THE WING}

window, but his legs were useless and the trap would only rest upon an even surface. With a clatter of iron, which drove the starlings expostulating from the buttresses, he slipped back to the leads.

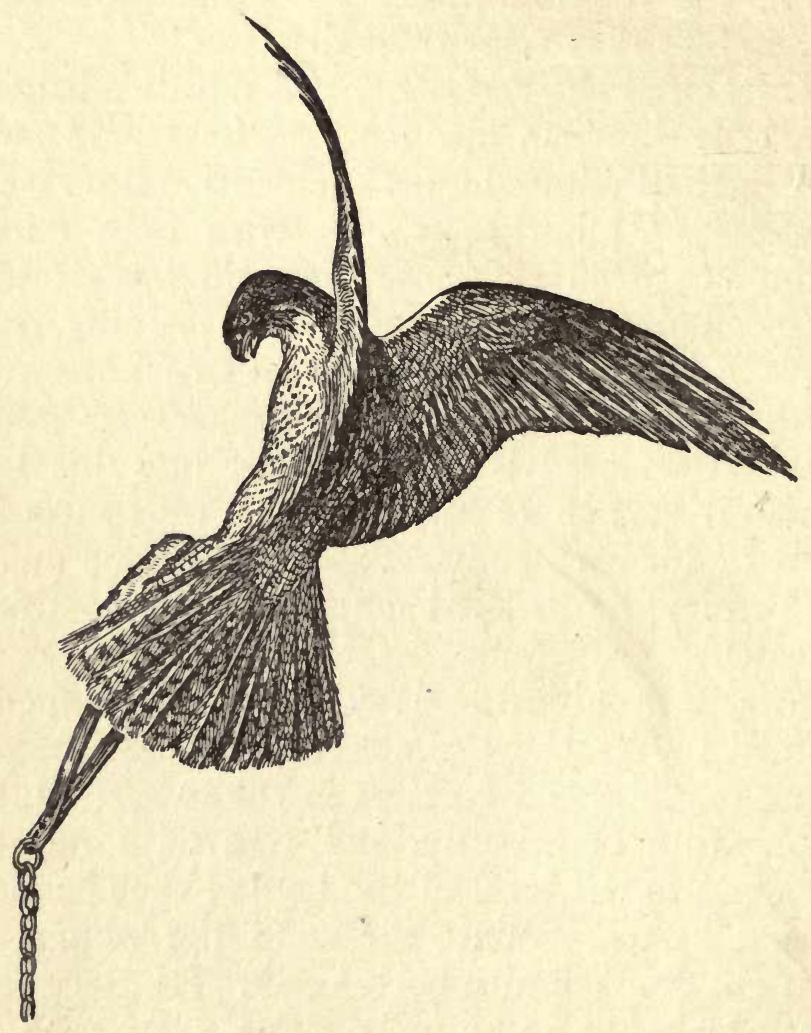




\section{V}

That night it rained-heavy, splashing rain. By dawn the roofs were clean-washen and wet, and a grey plaited current surged down each gutter-way. Iolar drank, and then being sick with hunger trailed himself over the slates in search of food. But the pigeons and daws took wing at his coming; and the sparrows straddling on the dripping stones heard the clank of the chain and scuffled away. Little enough remained of his former feasts, the jackdaws were expert scavengers. He tossed aside the fragments they had left-sundried, rainsodden. Sometimes his limbs ached as though the jaws of the trap were slowly gnawing them asunder, but more often they felt numbed and deadinsensible even to cold. When they hurt him, he turned and fought the iron-fought it until his tongue bled and the edges of his bill were notched and worn. When the more merciful but no less deadly numbness soothed him again, he huddled down with the grey membrane drawn over his eyes and dreamed-of the Atlantic crags perhaps, or maybe of the upland bogs and moors of Donegal, whose granite-crowned hills and quagmires give safe harbourage. 


\section{WILD LIFE ON THE WING}

Seumas Skerritt came up the tower and sought for him, and Iolar screamed and dragged himself along the leads where the man dared not pursue. In his fear he slipped off the transept roof, and only won his way back after a frantic struggle (he who had been bred on the heights of Slieve Crogher). But the man did not pursue him. Instead he went away and left a piece of meat behind him. Iolar's gorge rose against it, and he loathed the man the more. Crippled, starving as he was, he would not suffer the last degradation of accepting his betrayer's gift. He turned his eyes away from the flesh and the jackdaws ate it.

The next day passed in the same fashion, but Cudóg the daw and his clan became bolder. They foraged in the town middens and brought their booty to the church roof to eat. Three days ago they would not have dared to gormandize and riot under the falcon's eyes. Now they were insolently bold, romping and squabbling up and down the aisle roofs regardless of him. Towards midday, when they had finished their repast, they flew to the south porch to preen and gossip and then-supremest degradation-Iolar furtively searched the roofs for their leavings. Even so he found little enough : a bit of mouldy bacon-rind, a stale bone-offal, such as he had never tasted 64 


\section{THE PEREGRINE FALCON}

before. Now he stooped to carrion like any crow.

The sparrows collected round to watch him. Their crops were tight with gleanings from the car-rank down below. One or two ventured so near that had he been free he could almost have struck them down without spreading wing. He hated them - their plump round breasts and bright eyes-as Ugolino in his tower must have hated the oxen who browsed under the wall. But as he dragged himself about the leads a great fear constantly haunted him that he might slip or be blown from the roof and so fall into man's hands in the gravelled terrace below. On the second evening he flew from the chancel gable at a bat who blundered by. $\mathrm{He}$ missed his prey, for a falcon strikes with talons and his feet were useless now ; but as he tried to regain the gutter-brim, the weight of the trap drew him earthwards. It was only the thought of the man who, for all he knew, might be waiting to seize him at the bottom that lent him strength to struggle to the roof, and after that he dared not stoop at winged prey again. At night he would drag himself to the chimney which, under cover of the tower, carried away the smoke from the church stoves; for huddled between their cowls there was less danger of being blown away and moreover he could 


\section{WILD LIFE ON THE WING}

wedge the trap on the little platform, and so ease the strain of balancing himself upon its unsteady iron keel. The man came several times but Iolar, who had lost nothing of his alertness with his freedom, never allowed him within arm's length, and no bait would lure him to another trap. Each time the man retreated grumbling.

Then one night it froze again. Ice formed solid and black on the leads, and starry frost crystals glistened on the slates in the moonlight. In the morning Iolar woke to find himself in a bald wilderness of stone where no water was. He struck the hard ice in the gutter-pipes and flung the splinters about, but the water was frozen solid to the metal, and he had nothing to drink.

The daws came down from the tower to pry at him, with saucy jibes, and shuffled galliards upon the gable tops. They brought gleanings from the middens round about, and when they had eaten all they would, they threw the pieces over the roof, and had diving races after them. Iolar watched them hungrily. Now and again he would have shuffled forward to snap a bone or some such garbage, but always before he could do so one of the rabble swooped down jeering and bore it off to the tower top before his eyes. 


\section{THE PEREGRINE FALCON}

They tired of their games as the sun crept behind the buttress and cast the tower's broad black shadow across the roofs. All day the frost had nipped ; now in the shade it fastened tighter. North and east the sky was flooded with rose colour, and the chill air was full of the distant clamour in the streets below ; for it was Christmas Eve, and men were all abroad preparing to keep the feast of the birth of God. One by one the lamps were lighted in the houses and streets, and on the masts of the ships; and as the sunset paled Cor Caroli started on his everlasting circuit of the north. Seumas Sherritt did not climb the tower that night, because he was busy about the church, preparing it for the festival. If he had done so, he might have picked up his captive almost without a flutter, for Iolar had scarcely strength to gain the sheltered nook at the junction of aisle and nave above the sacristy door.

He should have died of that night's frost. The full moon rose behind the cross on the chancel roof, and, bisected by the transverse arms, it seemed to grin. The sky was clear and black as the ice. The daws in the tower slept soundly, lulled by the cold : men slept down in the town. Iolar huddled on the slates in the dreamless lethargy which is the last, but not the least, of Nature's benefactions to those 


\section{WILD LIFE ON THE WING}

of her children who die in the frost-time. Yet all through the bitter night his heart faithfully drove the sluggish blood through his veins, and would not let him freeze.

The moonshine went the road which the sun had gone, but before the shadow of the tower had passed from the roof the bells rang in the keen red dawn of Christmas Day. The great carillon of St. John pealed, and every lesser spire in Durrowmore and all the country round chimed an answer in jubilation. The lamps in the church below glowed ruby-red through the robes of St. Mary the Virgin and of St. Joseph, whose exalted faces looked up to Heaven from the clerestory windows, until the first sunbeam quenched their light as it had already quenched that of the morning star; and the people trooped along the frosty streets to worship.

Iolar awoke. Had there been a drop of moisture on those barren roofs he would have been frozen to the slates, trap and all, but every gutter and gable was bone-dry-as dry as his throat. Waking to fuller consciousness of misery, he saw the daws sit in a row upon the sacristy roof below him. Cudóg, their leader, grey-naped and saucy, turned a shrewd eye upon him and jeered: "What-ho?" Sitting up there was he, and impotent? Let them 68 
THE PEREGRINE FALCON

bait him. Good sport, that, to stretch their wings of a cold morning. Cudóg swooped upwards, flicked him with an impudent wing and straddled the transept gable, hooting derisively. Up came another, eager to outvie his leader, sidled within an inch of him, daring him to strike. A third soared up and dropped a rotting acorn husk upon him. Still Iolar did not stir, only his closed eyes opened ever so slightly. They came about him like bees, full-fed, scornful, flinging their noisy insults at him-those whom formerly he had despised. One buffeted him, and he drooped sideways limply. The whole mob jeered with glee. They were getting their own back now. From the gable, Cudóg, the noisiest of the band, swooped down, and the rest looked on delightedly, applauding each new jibe. As through a red mist, Iolar saw the mocker glide to and fro before him. All the world was dizzy with light and noise. The roofs were incarnadined with sunshine, red as blood: the light glancing from the daw's bright wings made them glisten. Far down below in the church the blare of the organ answered the pealing of the bells :

"Gloria in excelsis Deo; Et in terra pax, hominibus bonæ voluntatis-"

The clamour of the daws sounded like mocking 


\section{WILD LIFE ON THE WING}

laughter. Cudóg swooped upwards yet again, and like a stone Iolar dived down to meet him. The iron gin struck the jackdaw squarely across the wings. Then the frozen earth rushed up to meet Iolar, and somersaulting headlong he fell to the threshold of the sacristy door at the feet of Seumas Skerritt.

\section{VI}

He should have died, but death comes hardly to such as he, who for most of their lives have Fear and Hunger for their portion. Hence he struggled back to life in spite of frost-bitten feet, a bruised head, and a breast-keel pinched so sharp by famine that it seemed to be pricking through his feathers. That angel to whom is deputed the marking of the fall of the sparrow, and presumably of other birds, and whom Mr. Watts has painted for men's learning, may well have shuddered anew and wept for Iolar. But Seumas Skerritt had never heard of such an angel.

He put his captive in a coop under the lean-to in his back-yard, a small dark place where the December sunshine could never penetrate. Thin fowls trespassed there to ransack the rotting cabbage stems and empty cans which cumbered it, and leaner cats made the nights 


\section{THE PEREGRINE FALCON}

hideous. Every day the man came to renew the food and water which were so rarely touched, and sometimes other men came and peered through the bars. Iolar saw, without observing them. He seemed to have lived so long in that cage, and to have travelled such immense distances to arrive there, that at first he did not even feel afraid. All these things seemed to be part of the narrow painful existence which was now his life. Only, at first he could neither eat nor stand. But Seumas Skerritt, who saw a way to turn one crown into two, rubbed his feet with whisky, set him by the fire to thaw his frozen limbs, and put raw meat and potheen down his throat. And whether it were this treatment, or his own hardy constitution, in a day or two he could stand unsteadily on claws maimed by frost-bite, and languidly feed himself.

He hated men, chickens and cats alike, shrinking up into the corner of the coop, with talons spread and ruffled feathers. $\mathrm{He}$ hated also Seumas Skerritt's fat quiet little boy, who made mud pies by himself in the yard.

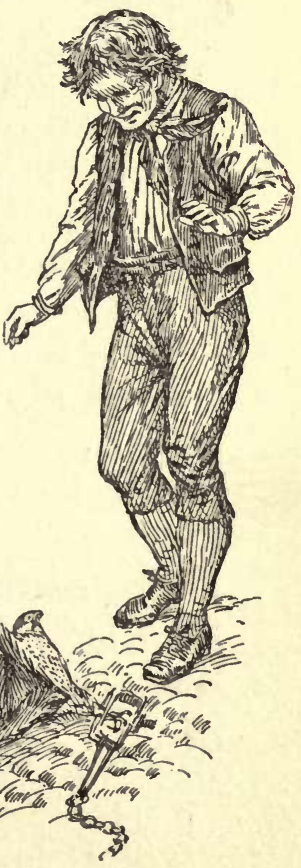




\section{WILD LIFE ON THE WING}

"Where did he come from?" asked the child, when Iolar was first brought in.

"I'm after catching him on the church," said his father.

The child looked up at the golden vane so high above his head, and then down at the prisoner in the cage. At last he said sedately: "Then he's very low down now." And he spent most of that day in watching the captive. Later, he brought sticky sweets and pieces of bread and poked them between the bars, but Iolar dashed about so fiercely that he ran away and was afraid to go near the cage again. Iolar was glad of this : he only asked to be left alone. He hated man and all his cunning. Nevertheless, every day men came to look at him. They blew foul smoke into the cage, and touched him with their sticks to see whether he were lively. He hated them all. When he cursed them to their faces for all that they had put on him, they laughed at him and twanged the bars. 


\section{THE PEREGRINE FALCON}

When they had gone he sat in dogged silence and nursed his hatred of them.

Yet he did not die. "The eagle's takin' his food all right," said Seumas Skerritt ; but Iolar only ate that he might live, and only lived that he might see the western cliffs again.

"When we have him tamed, we'll cut the wings of him, and see would he keep down the mice in the yard," said Seumas Skerritt, after New Year's Day ; but Iolar still screamed and struck at the hand which fed him. Man had betrayed him once and would betray him again. The only time he showed any interest other than fear in his surroundings, was when the daws-surviving mates of that Cudóg whose back he had broken-came furtively to peck among the rubbish in the yard. Then the fierceness came back to his eyes as he watched them, but they fed with one eye upon the open house-door, and had no time to bait him now. Even when he beat upon the bars in his efforts to reach them, they only sidled away intent on their foraging.

The frost gave way to rain. The fowls paddled up to the ankles in the mud of the yard. The child played at marbles on the doorstep instead of making dust pies in the rubbish with the hens. On wet nights the rain splashed and beat into the cage of Iolar 


\section{WILD LIFE ON THE WING}

until the floor was sodden. This was not Skerritt's fault, for he had nowhere else to put his captive, and it never occurred to him to set the latter free.

But after the rain came warm weather, and the grassblades which thrust up between the cobble-stones in the yard grew greener. On the steeple above the town the cock pigeons billed to their mates, and night by night the cats came and miauled to their loves on the roofs. At this time Iolar even began to welcome the presence of the staring child close to the cage-he kept away the cats. Three nights the peregrine awoke to find a pair of shining eyes fastened on him, and gradually velvet feet trampled a little track in the mud from the corner by the waterbutt to the cage. On the fourth night the moon was late, and before she rose level with the chimney cowls, Iolar, waking, heard soft-cushioned feet stirring before the bars. In the gloom shone unwinking eyes : further back another pair and another. Iolar dropped fluttering from his perch. Softly Malkin purred to Malkin in the dark. Something $\operatorname{dim}$ and stealthy reared up, pressing against the bars, scraping at the lock. The door creaked under the weight : the besieger's eager breath carried a smell of garbage, and of other unclean things. Iolar beat against 


\section{THE PEREGRINE FALCON}

the deepest corner of his prison, forgetting that the bars which kept him in could keep other enemies out. Gently the cats tested hinge and bolt, and, finding them staunch, stretched soft paws between the wires and tried to scoop him within reach of their talons.

Dawn drove them away, but the daylight brought no abatement of Iolar's terror. When Skerritt tramped across the yard he shrank into a corner, and then fought and tore at the man's hand while he fed him. Traps, cats, and men were all part of the same inferno. The sunshine lay along the roofs. He could just see the gleam of it from his perch, but none reached the yard. $\mathrm{He}$ ate nothing all day. The meat his captor gave him remained untasted : his water-pot, fouled by the dust which his frantic wings beat from the floor, was untouched. Every time that the church clock clanged overhead, every time one of the human kind crossed the yard, he shivered. $\mathrm{He}$ fluttered and struggled against the bars so much that the child sometimes turned half-awed from his solitary play to wonder at his passion. That night, before midnight had crashed from the spire, the cats came again, and one, flamboyant-eyed, climbed stealthily to the roof of the cage. Her soft heavy breathing shook the frail door, and set Iolar shuddering with 


\section{WILD LIFE ON THE WING}

terror that there should be nothing but open bars between himself and this waiting thing. For two hours that cat squatted overhead, watching him as she watched at a rat hole, and until dawn he huddled in the darkness, wideeyed with fear.

Next day when Skerritt opened the door to give him food he flew at his hand, rejoicing vengefully to see the blood drip down, and, daring the man to touch him, cursed him for the night's torment. But Seumas Skerritt was not spiteful : he only grinned as he closed the door.

"The eagle's daunted these two days," said he to the child who watched him.

"Why is he daunted?" asked the child, coming a little nearer.

"Shure he's afeared o' ye. He wants to get out."

"Let him get out," said the child, sucking his finger solemnly.

The man laughed: "Faith, I will not. I'll have him sold to-morrow to a gentleman from Dublin that's after him, and thin you shall have a grand new cap and a pieceen of 'Peggy's leg,' Mick, me boy."

$\mathrm{He}$ went away whistling. Iolar sat still and watched the child. He wished that it would go away too, and leave him in peace 76 


\section{THE PEREGRINE FALCON}

instead of staring thus, with fat red cheeksstaring like a cat. But the child did not go. $\mathrm{He}$ still sucked his finger and stared. Although Iolar did not know it, his fate hung in the balance, as he shuffled uneasily under the stare ; and the poise was fine, for in the other scale were weighty matters-a new cap and a sugarstick.

The great clock struck the hour. It was growing late. In an hour or two it would be dark, and with the darkness came the cats. The child looked furtively at the house, but no one appeared at the windows, and the door was shut. He stole tip-toed to the cage, and Iolar shrank back in fear. With unskilful fingers the child fumbled at the bolt. Iolar pecked at him, and half-crying he called out that the eagle was a nasty fright, but he persevered none the less.' The cage door swung back. The child cowered behind it. "Tck-Tck!" he wheedled timidly. Poised on the threshold, Iolar looked up and for the first time for many days he saw the open sky. There was a rush, the draught of jubilant wings, and then the child gazing up, halfgleeful, half-afraid, saw the prisoner circle up above the roofs towards the west, before vanishing into the sky.

A great mottled feather fluttered softly to the 


\section{WILD LIFE ON THE WING}

child's feet like a benison. He picked it up, and with a little sigh stuck it into his shabby cap. Then he turned slowly into the house, for the sun was setting, and the western sky was bright. 


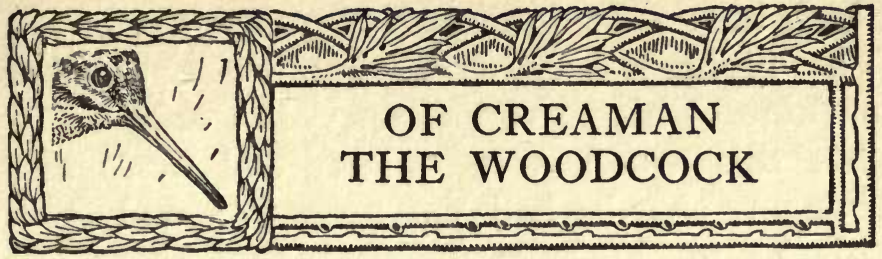

\section{I}

The February moon, with clouds thick over her face, was near her setting, when a traveller came over the hills, flying high with a steady wind blowing upon his right flank. Whether he knew his way is not known, but from the loneliness and darkness of the place it is improbable. Nevertheless, when he found himself above Garrybrack wood, he dipped and slanted down steeply to the trees. (Thus had his ancestors travelled in the wake of the full moon.) He cleared the branches by good chance, and dropped on to the dead leaves. A safe haven-his heart pumped hard. After many miles of open bog and moor, crossed with flagging wing, the peace and shelter of the trees were an unexpected boon. There are no other woods near Garrybrack. It stands by itself among the hills, like a gem in an ample setting; so that after all I am inclined to believe that this traveller may have set his 


\section{WILD LIFE ON THE WING}

course by some kind of chart in order to reach it.

The night was so dark that he could see nothing of his surroundings. He only knew that this wood was quieter and more airy than any that he had yet been in ; and from this he might have deduced that there was little undergrowth to shut out the night wind, or harbour soft-footed hunters.

But the stormy dawn, earnest of a rainy day, showed him his refuge, wide and bare, full of the sweet draughty airs which blew down from the hills. Garrybrack is a very old wood. The trees themselves are beeches, still lissom, and not thicker than a man's body; but their roots are deep in a stratum of the leaves and mast of a yet older wood, and they suck sustenance from the sodden jetsam of their parents. Here and there the stump of one of these older trees still stands, rotted by the corroding drip from its children's branches, and shaggy with moss. Every autumn lays down another carpet of dead leaves, and the ground, spongy with the black mould, is broken up by ancient rabbit burrows. The wood-people have lived in the wood for as long as the trees. There has always been a pigeon's nest in the old holly on the south side; twenty generations of stoats have been suckled under the pine stump; and 80 


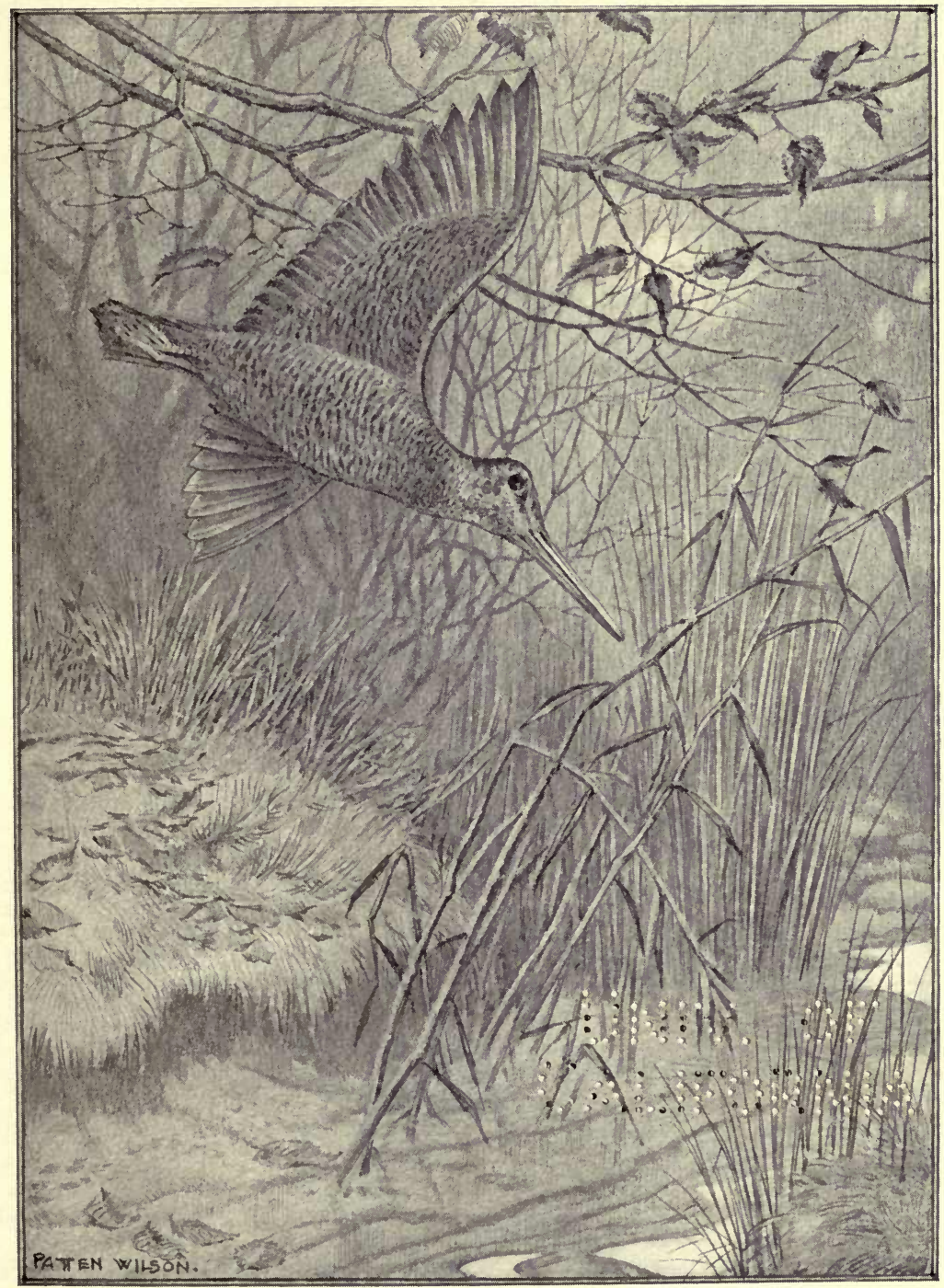

CREAMAN COMES TO THE WOOD 



\section{THE WOODCOCK}

the badger earth was, before the trees were. One year is very like another in Garrybrack: more beech mast than leaves one autumn perhaps-more leaves than mast the next, that is all the difference as a rule.

But though the traveller noted all the comings and goings in the wood from earliest dawn, he

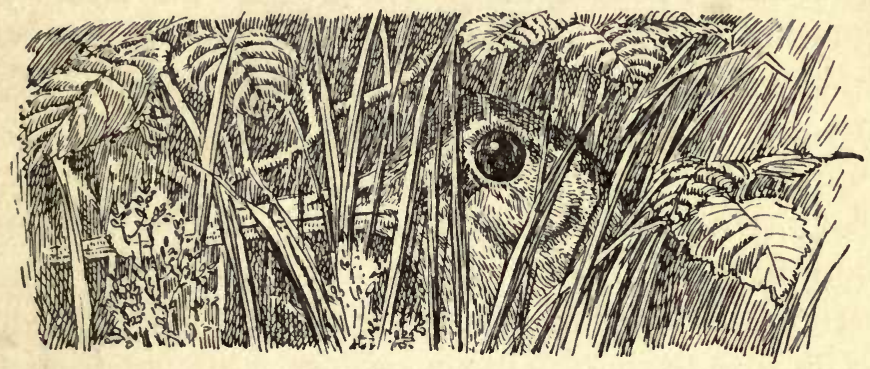

himself was not seen. The blackbird, raking for earthworms close by, never saw him; nor did Seabac the Hawk who drove the blackbird clucking to covert. Droleen the Wren danced a war-jig on a twig just over his "lie," and never saw him, for Creaman the Woodcock is never seen until he wishes-this is part of the wood-magic. Brown and buff, cunningly pencilled, met the dun and russet of the wet leaves, and the woodcock forthwith disappeared. The throb of his heart never heaved his feathers: he lay as still as if before Medusa's head. $\mathrm{He}$ was an impressionist picture copied by Nature 


\section{WILD LIFE ON THE WING}

from her own handiwork of the dead leaf and fern around: a study in tones, where every feather performed its own part in the scheme of shadings and in eliminating of the contour. Only his eye, alien to its surroundings, did not melt into its background with the rest of him. Round as a privet berry, and as black, it glistened like a drop of magic ink from a fortune-teller's bowl. Open, it was a clue to his whereabouts, if a little one-shut, its owner was invisible. Such is Creaman the 'Cock.

All day he slept under the brambles where he had first alighted, but at dusk he woke and stretched leg and wing. He flew the length of Garrybrack to take his bearings. Never a path broke the ranks of the trees from end to end. He passed the white owl, and the latter wheeled aside decorously, in salute to a brother nighthunter. To the west side of the wood are dense hedgerows of furze and bramble, between little marshy fields, and here Creaman alighted. He wetted his dry bill, and then probed the cow-dung at a streamside scientifically. As he worked he knew that he was not alone, for travellers were dropping in continually. Now a snipe "keked" contentedly as he stooped towards the glimmer of a pool; then a bunch of teal flew close overhead, quacking softly, 82 


\section{THE WOODCOCK}

and curlew passed up and down the country, calling in the dark.

The boggy soil of the field was loose, and carried the vibration of an impact as surely as a telephone carries sound. The woodcock's bill, sensitive as an antenna, detected the splashing thud of a single pair of feet. Instinctively he flattened himself on the grass, and looking upwards saw a bright peculiar star burn ruddily above him. The stir of breathing was louder than the swish of wind in the rushes. Creaman's bill was deep in the mud, and tumbled him head over heels as he started up. Four wing beats bore him above the red star, but even so he saw it shift as though to watch him out of sight. He did not hear the exclamation, muttered through teeth clenched on a pipestem: "Whirrah! the 'cocks is in again!"

\section{II}

At one end of Garrybrack lived a man, whose name for certain reasons is not given. The wild-folk simply called him the Man, just as he in his turn spoke of the Devil. But the Man did not fear the Devil, as the wild things feared the Man. They knew him as a branchcracking, earth-shaking monster, more to be dreaded than any other hunter, in spite of the 


\section{WILD LIFE ON THE WING}
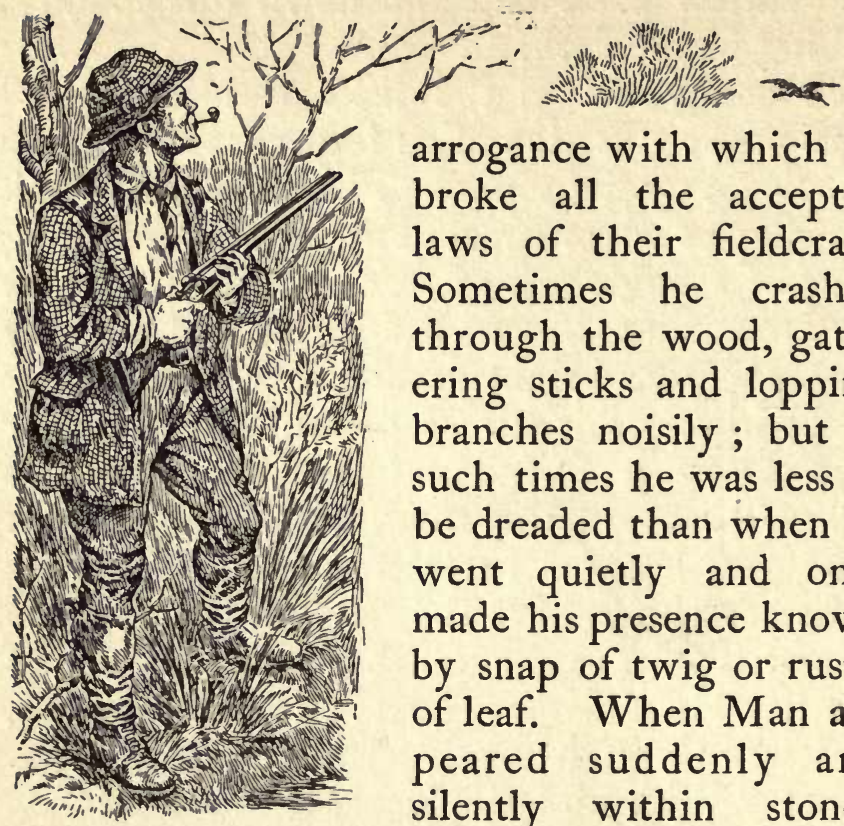

arrogance with which he broke all the accepted laws of their fieldcraft. Sometimes he crashed through the wood, gathering sticks and lopping branches noisily; but at such times he was less to be dreaded than when he went quietly and only made his presence known by snap of twig or rustle of leaf. When Man appeared suddenly and silently within stone's throw, then he was most dangerous. Man had thunder and lightning at his command, and the hail which accompanied them laid blood-trails across Garrybrack.

This Man had knowledge of woodcraft (as men know it), and he knew that a woodcock by the spring at dusk means a woodcock in Garrybrack next day. Accordingly he went thither early, accompanied by an old white spaniel who ranged over the dead leaves very scientifically.

84 


\section{THE WOODCOCK}

Creaman was taking a sun-bath under a hollytree, exposing his flanks alternately to the genial warmth, when they found him. He paid no attention to the Man; the dog he treated as a fox. That is to say, he allowed it to approach within a few feet of him, and then rose leisurely, wondering why it did not spring. There was a deafening report and a whirl as of invisible hail enveloped him. Creaman threw himself sideways and skimmed obliquely between two branches, and the second shot clipped the twigs above his head. He whirled down the wood in panic at a rate of sixty miles an hour, and dropped into a thick furze hedge. It was a peaceful place but for the pigmy squabbling of the shrew-mice, and he dozed there until evening.

The night was mild with a foggy moon. The hill of Scarabeg stood over against the wood, steep and black. The golden plover flew thither piping very joyfully and Creaman also went up the mountain. It is shaggy with gorse and ling, and nothing lives there in summer but a few rabbits and the unhunted foxes which stalk them: in winter the snipe and the curlew and the plover and other waterloving things go to its bog-capped summit to drink and bathe in brown peat water, spangled with the reflections of stars. The clefts in the 


\section{WILD LIFE ON THE WING}

granite held the pools of amber water as goblets hold wine, and the night was loud with voices, for these were the flighting times of the Feather Folk.

In the pool where Creaman wetted his bill, a brace of teal splashed the water over the brim,

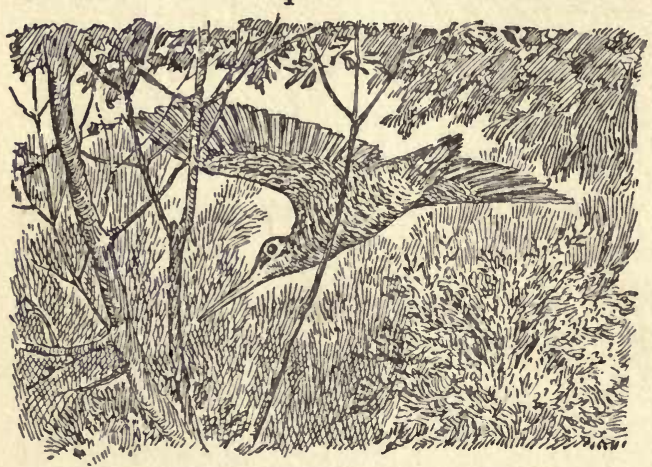
and dabbled in the mud. Elsewhere, Crutac the Curlew, with the salt from the sea-flats still crusted on his knees, fed beside a tired jack-snipe newly come from Scotland. Even when the greater part of the crowd had settled to their feeding, there was a subdued clamour and bustle all night-the discoursing of low voices, and soft squelch of feet in the mud-as birds dropped in for an hour or two to drink and bathe before starting on their journey west again.

There was a tussock of yellow bog grass at the edge of the pool, where a bird might perch clear of the mud; but though there were plover and snipe all round it, none of them perched upon the tuft, but hovered above it 86 


\section{THE WOODCOCK}

and then dropped aside. Presently Creaman toddled near the place, and a long bill like a bee's sting darted out at him, not so much in attack as in warning, and he fell back in astonishment. There was some one already in possession, one like himself; and the law of the wild forbade him to oust her. As he looked he caught her eye, and instantly her contour sprang out of the picture, limned against the darker rushes. She was resting, but even so no other bird might share the chosen spot with herat least, not yet. So Creaman dabbled in the

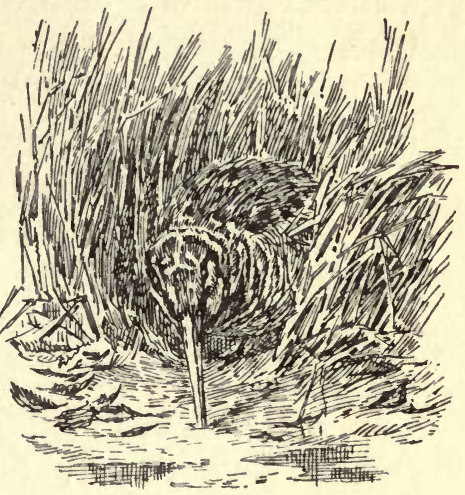
mud at a respectful distance, hesitating whether to make another advance.

There was a little path which led through the heather to the pool. Few people live on Scarabeg, but the track was beaten hard with claw-marks, and night laid a taint on the place which the day's sun or rain could not wipe away. However, the ducks did not know this, and one old mallard, guzzling mud rapturously, waddled opposite the place. Instantly the fox sprang, and gripped him by the neck. A 


\section{WILD LIFE ON THE WING}

startled quack died in his throat, and he fell, wheezing, with his crimsoned bill in the water. The fox snapped right and left as the rest of the duck rose out of his reach. Plover, curlew, and snipe joined the mob till the night was noisy with the racket of their wings as they whirled over the brow of the hill; and with them vanished the woodcock from the grass tuft.

Only Creaman, still crouching under the heather, saw the banquet, and how the hunter washed his red chops in the pool. There are few in the wild who dare to watch the fox break up his kill, but the woodcock is one, for none-fur or feather-can hide as closely as he. But though Pillibeen the Plover and Crutac the cunning Curlew came back to the pool before all the luckless mallard's feathers had blown away, the grass tuft remained empty, and no woodcock came back to fill it.

\section{III}

Creaman lay among the rocks of Scarabeg, and more and more of the Feather Folk came in as the clouds piled up in the north. At noon it began to snow in flakes as big as a man's thumb, which clung unmelted where they fell. But the warmth of Creaman's feathers thawed 88 


\section{THE WOODCOCK}

the snow immediately round him until he lay enclosed in a crust of snow. He awoke at dusk to find that the mice were scuttling over his head, and that one had broken through upon him where the surface was thin. Scattering mice and snow, he burst out of his prison into a frigid world. Scarabeg was white; the lowlands were whiter, parcelled out into blank fields by the dark hedges.

was a gloomy prospect for the Feather Folk. Even the need for food was second to that of water, but there was none to be had. Creaman tried last night's drinkingplace: it was choked with snow and halffrozen. A duck alighting on the sludge might have broken it in, but a woodcock's weight was insufficient. A few weary plover stood near, patiently waiting for the thaw which might be many days away. There was no hope here. Even the water-trickles among the heather were all choked with snow. The lift, from Scarabeg to Slieve Corrig, hummed with anxious birds-fore-wandered bunches of 


\section{WILD LIFE ON THE WING}

plover, wisps of snipe and hungry duck and teal. It was almost dark by then, but Creaman, roaming aimlessly through the snowstorm, felt the presence of trees below him, and by good luck he dropped into Garrybrack. The water stood unfrozen in the hollow where the Man had shot at him the morning after his arrival, and the place was crowded with woodcock. It was too dark to see them, but he heard the rustle of leaves where they worked, and the soft squelch of their bills in the mud. But they took little enough for their pains-two torpid worms, or maybe three, were all that rewarded them. The snow ceased at midnight; and then the ground froze hard, and the water was darned across with ice needles so thickly that the birds could no longer wash their bills. From the pool the ground sloped up to the hedge, and there Creaman crouched wakefully till morning. Then the wren found him.

The hedge is hollow with old rabbit holes, and so thin that a man can creep through it anywhere. It is a lonely place and damp, with little to commend it to fur or feather, but, such as it is, it belongs to Droleen the Wren. Droleen was mateless at that time, a fussy cocktailed bachelor. $\mathrm{He}$ owned twenty perches length of the hedgerow, and took care that nothing from a man to 90 
a beetle should stir in his domain unchallenged. He is a good watchman-Droleen - with a throat like a fairy policeman's rattle, and in colouring a little woodcock, russet and sepia pencilled. During the week that the cold snap lasted Creaman learned to recognize his alarm note of twenty lilliputian curses run together into a trill, and to regard it. No matter how busily Droleen was grub-hunting, the thud of the Man's approaching footsteps never failed to send him skimming through the brambles like a minute partridge, and his challenge always woke Creaman. For a week the Man came constantly through Garrybrack with his dog and gun. The woods were littered with the empty brown cylinders which showed where he shot. In fact Creaman became quite used to the periodic alarm, and even adapted to the peculiar hunting methods of the dog a trick which he had proved efficacious to deceive a fox. In the middle of the bramble patch was a clump of beech saplings to which the shrivelled leaves still clung. Underneath it was passably warm and dry, and Creaman often lay there. With his soft mottled plumage and shifting flight, Nature has given the woodcock what is as good protection as either-his faint transient trail. Hence the dog must be very close to wind him, and as he walked slovenly 
WILD LIFE ON THE WING

footed over the dead leaves, Creaman was generally awakened before he came to the place. Then, when the dog's head was thrust between the saplings, he would spring up some six or eight feet, and bounce back to earth a little distance behind his former "lie." The dog never became used to this manœuvre. He always waited for the report of the gun, and when it did not come, he used to range forward again. After alighting Creaman always ran away at right angles to the place. $\mathrm{He}$ ran in quick little bursts like a plover, and carried his long bill through the briars with great dexterity. When the dog was recalled the scent was cold, and he either missed Creaman altogether or else flushed him out of gunshot.

The cold snap lasted while the moon dwindled to its last quarter, and then came a thaw. Even then, when most of the other woodcock left Garrybrack, Creaman with a few of his kind remained there. But each popular feeding ground had been so well probed that the survivors were put on short commons, and were driven to the most dangerous and barren feeding grounds.

The Man's house stood at one end of Garrybrack, and night after night its light burned steadily between the tree trunks. None of the Fur Folk trespassed close to the place, because 92 


\section{THE WOODCOCK}

the taint of man warned them away, but Creaman knew nothing of that. There was an open space round the light, and, exploring it one evening, he found himself upon clay which adhered lusciously to his claws. He was too hungry to heed sundry strange noises which came from within the house while he fed; so that it was not until something rattled close at hand that he looked up and saw the fat white spaniel snuffling suspiciously in the gloom. By daylight Creaman's eyes were scarcely serviceable: at night their powers were almost miraculous. He knew that he could not be seen : he felt vaguely that the dog belonged to the daylight, and therefore, after dark, must work under the same disadvantages as he himself did in sunshine. So he merely picked out a worm with scientific precision, and paid not the slightest attention when the dog began to whine and strain at his chain.

The lamp in the cottage window laid a broad beam of light across the garden, and several winged things came to marvel at it-little whirring moths, and a bat or two. Creaman saw these, for it is not the least of the woodcock's gifts that he can see what goes on all round him, when his bill is nostril deep in the earth. Here Nature surpassed herself in adapting means to an end, and set the 'cock's eyes 


\section{WILD LIFE ON THE WING}

out of harm's way behind his ears. He can see before and behind him, and best of all in the dark.

Hence he pulled up his bill with a jerk when something broad and bat-like whirled into the light, and he saw that it was as large and as dark as himself. Twice it somersaulted into the gleam and back into the darkness; but the third time it fluttered like a moth at a candle, and then flung itself at the window, and beat against it in a silly frenzy. (So had Creaman himself once fluttered and striven with other seafarers before the glare of a northern lighthouse in an autumn gale.) The dog began to whimper anew, but the lost bird, bewildered and intoxicated by the light, only tapped and struggled on the sill.

Suddenly the cottage door was flung open, and Man, maker of light where no light should be, strode out. He saw the woodcock at the window and clutched at it, but struggling under his hand, it fluttered free, and disappeared into the darkness.

"Gosh!" said the Man (and the people of the night listened apprehensively to his voice-the voice of that dreaded hunter speaking to himself of his hunting). "We'll go look for that chap again to-morrow, Shot, me boy."

But Shot only tugged at his chain and whined, 94 


\section{THE WOODCOCK}

because there were now two woodcock to windward of him.

It was a far cry from a Scarabeg peat pool to a cabbage bed in the Man's garden, but Creaman had no doubts. Moreover, the spring was half a moon older than when she had repulsed him from the rush tussock. Where she had been in the intervals Creaman did not ask, and therefore nor need we. Enough said that the earth near the cottage door was punctured by galaxies of neat borings, and a double track of feet ran up and down the cabbage rows next morning.

IV

Droleen the Wren always patrolled his section of the wood precisely once up and back again before he settled down to the serious business of the day. It was the first morning of March. When the blackbirds scraped away the leaves they discovered tentative primrose plants, and Droleen sang lustily under the rare stimulus of the sunshine. Five mornings out of seven he knew that the woodcock lay among the beech saplings, and he spun through the brambles like a pigmy partridge, and spoke his mind until the sleeping bird opened a lustrous eye. But this morning Droleen saw 


\section{WILD LIFE ON THE WING}

two eyes opened, one by a sapling and another under a fern stub, and two woodcock suddenly appeared among the dead leaves. He went down, and took his breakfast between them. Droleen was thin nowadays, and always hungry, but of never-failing cheeriness. $\mathrm{He}$ talked to himself all the time, and even hopped on and off Creaman's mottled back, while the latter blinked blissfully in a broad gleam of sunlight which filtered through the branches.

They were thus occupied when the report of the Man's gun made the woods shudder. He came along the hedge, and the melancholy hedge-sparrow who shared Droleen's allotment, began to pipe cheerlessly.

Creaman pulled himself together for his customary trick. "Gerr-r-r," scolded Droleen as the dog snuffled up. The other woodcock quivered and scuttled away through the brambles, and when the dog came to the place the trails forked. The white dog hated woodcock-only long habit made him hunt them at all. While he stood uncertain which line to follow, Creaman flounced up and instantly dropped palpitating, because the Man unexpectedly stood right above him. This man was a hunter before he was a sportsman : he killed not merely for the love of killing, but for the pot. He saw where the woodcock had 96 


\section{THE WOODCOCK}

dropped, but no sooner was Creaman among the leaves than he became invisible. Nevertheless the man raised his gun until the end of the barrels was like a double eye staring at Creaman. At this, Creaman's nerve forsook him, for the wild folk instinctively hate anything which stares. He burst up like a puff of brown smoke, and dashed away down the wood, but not too quickly to see that his companion was already almost out of gunshot to his left. There was a second fusillade as she got up, and the next minute a noisy whirring shadow eclipsed the sun above him, and she dropped down trembling. By day a woodcock's wits work slowly as do his eyes, but when he is once roused he lives in wakeful panic for the rest of the day. This Man was a persevering hunter, and would follow a woodcock up and down Garrybrack for hours in hope of a shot. He flushed this couple three times, and on each occasion they rose more wildly and flew faster than before. When at last the woods were left in peace, Creaman found himself alone, and the solitude was oddly distasteful to him.

At nightfall he remembered the little pool in the swamp near Droleen's allotment. It was a still dimly starlit evening after a day of transient brightness, and some shrew-mice were eating 


\section{WILD LIFE ON THE WING}

their supper under the first primroses. The wood was full of little singing winds, carrying strange new smells. Creaman was wont to fly low to his feeding grounds; to-night for some reason he mounted higher, and he flapped softly along the woodside like an owl. Even before he alighted, he knew that he was not the first comer, and at the thrum of his wings she fluttered aside to give him space to land upon. The sight and feel of her set Creaman's pulse throbbing, and drove him aloft again in an ecstasy.

He thought he was alone in his passion, but as the twilight deepened the woodcock people came out from fern brake and covert. Garrybrack hummed with their voices-the flutelike "chissick" which cuts the ear, and the deep "hoo-hoo" which is Creaman's declaration in the springtime. Each 'cock chose his route and kept to it. Creaman started down the middle of the wood, where some gale had ploughed a furrow through the ranks of the trees - a clear flight of a hundred yards, where he croaked as he went. Then there was a sharp turn where the wood was cut short by the lane, and he called shrilly here like a bat, that she (waiting by the pool in the swamp) might know that he was returning. Next he made a wide sweep up the bohireen,* and over the * Bohireen = narrow lane. 


\section{THE WOODCOCK}

trees, in silence, until he caught the glint of water in the Pool once more, and began his serenade anew. So he flew, round and round, until the light faded behind Scarabeg, and then he dropped into the swamp at last.

They fed side by side that night. She never encouraged nor yet refused his presence, and now that the frenzy of his flight was over, he was content to feed quietly beside her. But at daybreak he flew again, and told the fading stars about her, until the other 'cock loitering in the wood heard him and came out also. Each kept strictly to his own high-road through the trees; and they flew round and round until it was light enough to distinguish the purple of the beech buds from the green of the pines. That is how the woodcock goes "roading" in the spring.

Thus ran their courtship at dawn and dusk, and at length one morning Creaman took the "lie" closest to her own, hustling away all rivals. The Man still walked through the woods, for, as we have said, he shot for the pot, and cared little for Acts of Parliament. There were now few but home-breeding woodcock left in Garrybrack, for the last migrants 


\section{WILD LIFE ON THE WING}

left the place before the equinoctial gales, which came early that year; but the Man did not care for that. He came into the wood one night after sundown, and leaned against a tree trunk: the white dog lay beside him sighing in his dreams. The rabbits knew that they were there, and stamped a warning, but Creaman did not know rabbit-talk, and even if he had, I doubt if he would have listened-he so full of the love-longing that night.

The Man heard the "chissick-chissick" as Creaman twisted round the corner of the wood, and the deep "hoo-hoo" as he flapped overhead; but he flew in the shadow of the trees, and although the Man held the gun to his shoulder and followed the voice as it shifted along the clearing, he never saw his mark until Creaman turned at the bohireen.

That shot was a long sixty yards, but the Man had an idea that the woodcock was a delicate bird, to be brought down by the least " tashte o' shot." The light was failing, and it was fate rather than sure shooting which guided the charge. Creaman dropped down into the road half-stunned, but the patter of the dog's feet racing through the wood roused him. He rose again laboriously, leaving a row of crimson drops on the mud behind him, and fluttered 100 


\section{THE WOODCOCK}

into the wood. The dog ranged down the lane, but soon gave up the search.

"Shure, it's no manner o' use takin' thim long shots in the dark," the Man told himself disgustedly as he turned homewards.

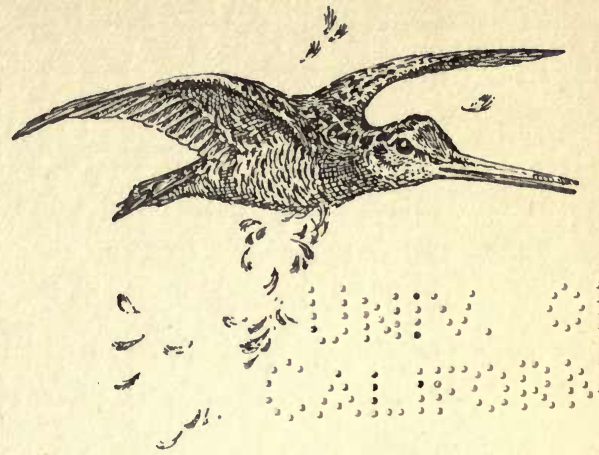

But he recognized this fact too late to help Creaman.

The rest of the woodcock in Garrybrack had long since settled down to feed before Creaman flew in, and when he alighted by the swamp he found that his place was filled. He hustled the intruder away, and found her little interested in his coming. She probed assiduously for food, but Creaman scarcely ate anything. $\mathrm{He}$ huddled under an alder bush, and tended his wounded wing. In the woods there are two panaceas employed for all ills, and they cure many. The first, time and clean living, man has wearied of, and often calls in drugs to supplement. In the second-massage-he has rediscovered a remedy which has been used in the woods since Nature gave her children bill to preen, or tongue to lick with. Creaman massaged his wounded sides all night long and 


\section{WILD LIFE ON THE WING}

rearranged the feathers round it tenderly. By dawn, when he went to his "road," it would have been hard to tell that anything was amiss with him, only for a purple stain on the leaves where he had been lying, and he flew as well as any of his peers.

He.:Won the "lie" closest to her, under Droleen's brambles. He dozed wakefully, and wohenear noon she stretched herself in the sunshine, and quietly left the place, he followed her. On the other side of the swamp there was a fern stub whose withered fronds curtained a little hollow. She spent over an hour at this place, and he waited in respectful attendance a little distance apart. When they left the little hollow, together, it was no longer empty.

The hen woodcock squatted down in her old "lie," but Creaman puffed out his feathers (though the effort tore open his wound again) and pirouetted round twice proudly. But when he turned round for the third time, she was asleep, and his head drooped again.

\section{VI}

Some say that there is no moral code in the woods, but only wonderful Instincts. I pray you, mark this, and then marvel at the distinction made between morality with a minuscule 102 


\section{THE WOODCOCK}

and Instinct with its capital letter. Then we may consider the story of Creaman the Woodcock, and judge it by whichever light we please. For if Creaman had been a man I should say that he played the part of a brave gentleman for the next two days, but as we are dealing with a bird, we will only wonder at his instinct; not, however, forgetting that both moral codes and instincts somewhere deep in the sands of Time may have had a common root.

All the next night he kept his place beside his mate, and the next day he saw a second egg lie under the fern stub beside the first ; and that evening he flew again, and upheld the honour and beauty of his lady (or its equivalent in the jargon of woodcock chivalry) against all comers. But he scarcely ate anything on either night, and was weak and tired by dawn; for the fire of Creaman's vitality, like that of most birds, requires much fuel, and he was too dull and depressed to seek far for food. But in spite of it all he did his duty those two nights.

There have been strong-flying 'cock in Garrybrack ever since-blood of his blood, and bone of his bone-to whom he gave his own pluck and stamina-witnesses whose very existence was proof of the stout fight he put up against pain and languor for three days. 


\section{WILD LIFE ON THE WING}

In every wood there are certain "lies" which the woodcock love above all others, but there is an unwritten law that when one bird is in possession no other may oust him. But if for any reason the coveted "lie" is left empty for ever so short a time, the second woodcock may slip in, and cannot in his turn be driven out. Therefore, though you may kill a 'cock out of a certain brake every day, you will always find that as long as the woodcock continue to come into the country, his place will be filled again next morning: but whether the cock tries every favourite spot in turn, or if not, how he knows that it is empty, is a part of the woodmagic which men do not know.

That is why Creaman flew so strongly every morning: he knew that if he were late in returning that some one else might have slipped into his place at her side, and that he could not brook.

On the morning of the fourth day, however, he could not fly at all, for his wound was too stiff and sore, so he lay still. She took little notice of him: she was thinking perhaps of her umbermottled eggs in the nest by the swamp. Early in the afternoon she laid the fourth and last, and jubilated over it. Towards dusk, a strange woodcock, flushed perhaps from some distant covert, alighted close by, and his presence I 04 


\section{THE WOODCOCK}

roused Creaman. He forgot about his weakness, and hustled the intruder so mercilessly that the latter was glad to hide himself under the brambles.

Twilight came all too soon, and with it time for the evening flight. Creaman stood up and stretched himself stiffly. He left a red smear on the leaves where he had been crouching. "Hoo-hoo!" croaked the late intruder overhead. A good voice-that! Well, he would see whether he could not beat it. He flitted from his "lie," and there was the faintest stir of listening in the brambles. Therefore, since Garrybrack was planted, no woodcock flew down that clearing with more dignity than he, though every wing-beat drove a pang through his side. He turned up the lane, calling so clearly that no one could have told how hardly his breath was drawn.

Twice he performed the rite in full, and though it was perhaps a little more sostenuto than usual, yet he gave each pause and call justly. The clip of his wings through the cold air warmed him, but he flew stiffly, and he knew it. The "cock-shut" light deepened into the clarity of the young starlight, as he flew above the swamp for the third time. Then something seemed to snap, and choking on his note, he fluttered feebly down into the bramble 


\section{WILD LIFE ON THE WING}

patch, just where he had alighted on his first coming to Garrybrack.

One by one the flighting birds dropped in, but he never stirred. At last, when the "false" dawn was still far off, a woodcock ran across the swamp so lightly that she scarcely left a footprint on the mud. She paused close to Creaman to wash her bill, and then passed on softly to the fern stub which was a few yards away. A minute later a keen ear in the swamp might have caught a low rustle of feathers, as when a sitting bird shifts from side to side in the nest to settle her eggs comfortably under her breast. It was the sign that Creaman's bequest to his race had passed into the charge of its proper executor, and might have right fulfilment by and by.

$$
\text { * * * * * * }
$$

... A simple place to lie out-by the open water. Even a waterhen would not have slept in such a place. The shade in the swamp under the trees was good hunting light for the owl. Woodcock was new prey, but it was feathered and still warm. ... The man, passing later, found the long smears where frenzied wings had beaten the mud, and the trailing claws scraped long scars. These were plain for all to see, but the Man was not woodman enough to mark the fainter smudge where the owl's wing 106: 


\section{THE WOODCOCK}

tip flicked the surface as he pulled up short in his pounce, and followed his fluttering quarry across the swamp. Therefore the man missed the last page of this history, as it was written in Garrybrack in scattered feathers draggled piteously. And neither did he find the four eggs under the fern stub, nor see the mateless woodcock who brooded over them.*

* In justice to what is as a rule the most useful and harmless of birds, it must be said that it is very rare indeed for the barn owl to attack and kill a woodcock; and then probably only when bad weather, or some such accident, has caused a shortage of the owl's proper food.-M. D. H. 


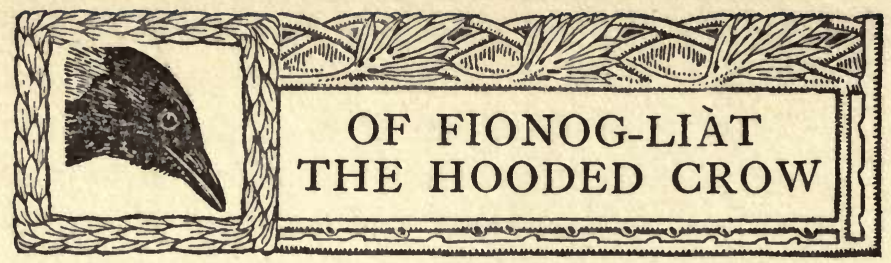

ThE stormy December day was drawing in. The wind swept through the wood in gusts, with now and then a patter of rain-drops, and the black tops of the firs swung to and fro against the grey sky. Below, it was still, for the boles of the trees were set close enough together to shut out the wind; and the only sounds to be heard above the sighing of the branches were the "chink-chink" of the blackbirds as they went to roost in the evergreens, and the occasional crack of a gun.

The pigeons with full crops flew in from the open country in scores. They sailed up, head to wind, to pitch into the shelter of the fir-tree tops, or dashed across the woods forty miles an hour to flutter noisily on to the bleaker perches of the oak-trees; and the ground at the feet of the man, who stood in the shadow of a big laurel bush, was littered with empty cartridge cases.

"It's almost too dark," said Driscoll, the keeper, I 08 


\section{THE HOODED CROW}

to his underling, who was collecting the ruffled grey corpses of the slain.

Between the heaving tree-tops was a patch of lighter sky, across which the cloud wreaths streamed monotonously, driven by the strong east wind. Half a dozen black flitting shapes suddenly wheeled across it, and dropped into an old Scotch fir, where the shade was deepest. "Scaul-crows!" said James Driscoll, cocking his gun; "but I'll let thim fellers have it. Hit the tree, Marty-see would they come out."

The double report of the gun, deadened by the roar of the storm, was followed by a chorus of harsh cries as the crows wheeled overhead. Two bodies crashed through the twigs and fell with a thud on to the ground below.

"Shure that's pretty fair shootin' for this light," remarked the keeper, complacently, ejecting his empty cartridges. As he tramped homewards through the wood, he heard the rest of the crows, fighting with the storm overhead, cry like a flock of lost souls.

$$
\text { * * * * * * * }
$$

Those were the fifth and sixth of their band who had come to a violent end since the crows had left the bleak dunes of the East-country, some weeks before.

Urged by hunger, and wind driven, they had 


\section{WILD LIFE ON THE WING}

crossed the sea by night, rushing through the air a hundred miles an hour, with the certainty that a north-easter from Spitzbergen would overtake them if they lagged behind, for already the lips of the waves were whitened below them-a portent of the strong, following wind. This little party of ten was but one link in that great chain of crows which for many days is drawn westwards when the winter famine begins to pinch in the East-country, and the polar winds curdle the snow. They croaked to keep in touch with one another as they flew, but the gale drowned their voices, and when day dawned and they saw dry land below them, two of their number had disappeared.

Then came three weeks of roving over the fells until the north-easter blew again, and, obeying its impulse, they travelled westwards once more until another and narrower sea was crossed-mere child's play to such wings as theirs-and they came at length to the Irish shore.

But one had been shot on a Yorkshire moor, and another had been poisoned by a Welsh shepherd, for every man's hand is against the hooded crow. He is an Ishmaelite, a wanderer, an outlaw, to be trapped, or shot, or poisoned, by anyone who is cunning enough to circumI IO 


\section{THE HOODED CROW}

vent him, and he trusts nobody - not even his own fellows.

Of the four birds who remained, Fionog-liàt was the leader. From the Liffey to the Slaney, he was the strongest and most cunning poacher that ever sucked an egg or killed a crippled bird; and day by day as the peak of his breast bone grew sharper, and his unsatiated appetite keener, his audacity and his guile increased.

There is a certain drab-coloured stretch of country at the foot of the Com-

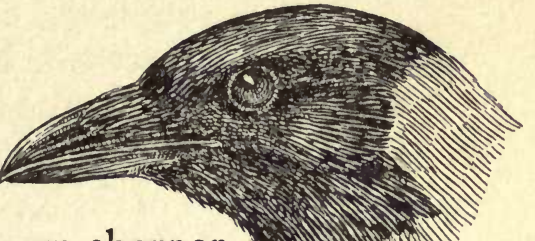
mergar Mountains where low walls fence the bog into tiny fields, which for the most part were shaven clean of all pasturage but rush tufts, by generations of starveling goats and cattle. Three miles to the south'ard a purple smear above a low range of hills showed where the Kilcool Woods lay; and to the east, snow ribbed the great barren slopes of the mountains. It was a desolate country, but such as it was Fionog-liat and his followers, outcasts in wildernesses, took possession of it. Day by day they patrolled the bogland up and down. They flew perhaps half a mile apart from one another; but if one bird swooped down to some spoil, the next in the line never 


\section{WILD LIFE ON THE WING}

failed to see him, and before the first-comer had time to gulp three billfuls, the rest of the band were circling round him eager for a share. The wounded snipe, squatting by a dyke in the bog, cowered down when the crows flew between him and the sky; but the eyes of the marauders were as keen as their bills, and the covert of sod or rush-tussock availed him nothing. They dogged the track of the fox's hunting, and as the month went on and the cold and its handmaid famine tightened their grip, even Fionog-liàt himself deigned to

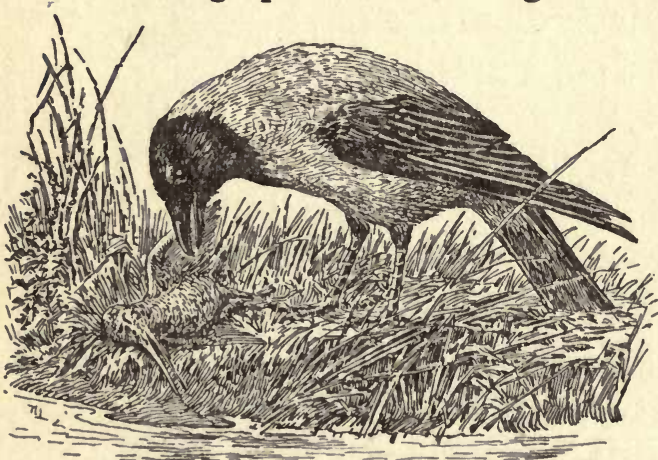
squabble with the rooks near the farmsteads for grubs and such small deer, which ordinarily he despised. All day long the east wind blew across the bog from the mountain. The scanty grass blackened before it, and the buds on the gorse bushes were blighted.

Fionog-liàt chose the beat which lay along the lower slopes of the mountain, and no crow in the fields below could stoop unobserved by his leader's keen eyes. The numbers of the band 


\section{THE HOODED CROW}

were fairly constant-sometimes there were only three, there were never more than six. It depended chiefly upon the straight shooting of James Driscoll, who shot a crow at sight when he could come within range; and moreover there were sometimes defections from the ranks when the kill was unusually meagre, for then one or other of the band deserted in order to join some other wandering party.

Every night at dusk all the crows in the countryside mustered in the fir-tree grove at Kilcool. All were lean and pinched with hunger, and many had travelled fifty or sixty miles during the day, but they came as blithely as ever for the evening flight. Fionog-liat was leader more often than not. With his band flapping close behind him he led the way across the wood, all wheeling and doubling at his signal as a flock of starlings doubles to evade the hawk. They flew silently for the most part, but in the gathering dusk more and more crows joined them, some solitary birds, some in couples or in larger gangs until there were a dozen or more, all turning and twisting like giant bats in a wild aerial dance. They flew close to the tops of the trees, and so near to one another that the feathers of any one of them were ruffled by the draught from his neighbours' wings. Sometimes, as he led the 


\section{WILD LIFE ON THE WING}

mad flight from the fir grove to the river, Fionog-liàt would sweep suddenly away at right angles to his course, and then as the last of the band wheeled aside in response to his leader's warning croak, as often as not he saw in a clearing far below the black squat figure of the gamekeeper, fingering his gun. But before he could bring the "sights" to bear, the crows were a furlong away, the wind purring through their tail feathers with the swiftness of their flight.

Later, they dropped into the Scotch fir one by one. All round them in the pine-trees, the plump, wary wood-pigeons perched in rows, grunting a little as the wind swung the branches to and fro beneath them. But if a belated pigeon, bewildered by the darkness, settled in the fir-tree, she clattered out again quickly at the stir of soft heavy breathing in the gloom. Then would be heard a sinister rustle as a dozen bills were unsheathed from the puffed-out feathers, and a dozen pairs of eyes glared fiercely into the darkness. Sometimes as the pigeon dashed away she heard half a score of clamouring devils behind her, who, empty stomached, all dreamed of a full gorge, and had awakened hoping to find the dream true. But when they heard a living thing fly from them, they blundered back to their perches, croaking discontentedly for dead meat. 


\section{THE HOODED CROW}

At dawn the same strange roll-call was held. Before it was light enough to distinguish Fionog-liàt's ash-coloured breast from his sable poll, the crows were swinging over the woods together, not in silence as at night, but with a clamour which made the woods resound. But before the sky was streaked with the hard gleams of sunrise, which shone through the eastern cloud-rock like coals between the bars of a grate, the flock had broken up, and departed to seek their different foraging grounds.

Fionog-liat recruited his band from the roosting tree, for often one or other of the starving birds would elect to throw in his lot with those marauders on the mountain slopes. Fionog-liàt himself never resented the appearance of these strangers, and the gang never took any notice of a newcomer unless he were by chance a weaker bird, and could be thrashed away from the killing. There was no spirit of comradeship among the crows. Each distrusted his fellow, and looked upon him merely as a tool by which to find food. They obeyed no law but that which gives the largest share of the spoil to the strongest, and this share always fell to Fionog-liàt. There were, however, two crows who invariably remained constant to the leader and his chosen beat. They were young 


\section{WILD LIFE ON THE WING}

males of the previous season, as alike as the two kernels from one beech-nut. They hated one another only one degree less deeply than they hated Fionog-liat, but they followed him although they also feared him, because under his leadership they found food more surely than when they foraged alone.

As the cold increased, neither fur nor feather was left on bog or mountain for the crows. They sought dead meat-only as a last resource will the crow strike where the blood runsand in spite of the scores of lives which the cruel weather took daily in the wild, it was hard to come by.

Thus when Fionog-liàt saw a possible victim, it behoved him to go warily, and allow no chance to slip. A wounded pigeon at the woodside, or a limping rabbit on the mountain, was not pressed too hardly at first, but merely headed away from covert and kept moving. Then, as terror and exhaustion did their work, the rest of the band, summoned together by their leader's call, outflanked the game and harried it to and fro in the open until the time came for Fionog-liàt to give the coup de grâce. Sometimes such a victim was marked down and followed thus for days, and as a rule the crows' patience was rewarded; but at other times the cripple recovered, or else the fox, or some other I 16 


\section{THE HOODED CROW}

hunter less scrupulous as to the shedding of blood, forestalled them, and they went empty to roost. No beast nor bird, from a sheep to a peewit, died between Commergar and Kilcool during the cold weather without some greysaddled sentinel to watch over it. James Driscoll, the keeper, in whose beat the bogland lay, learned to know the work of Fionog-liat's band. Rabbits snared at dawn were disembowelled and torn by breakfast time, and after a day's shooting, of such snipe as had broken back wounded to settle behind the guns, scarcely one escaped the crows. Fionog-liat, to do his sagacity justice, did not like forays in the woodlands. He had rather go hungry in the open country than feast with the risk that unknown things might be watching him from the covert of the bushes. He roosted among trees because he could not sleep in the bogs like a duck, or in the hedges like a redwing, but he hated them none the less, and was always happiest out in the bare fields. His followers, however, were less wary, and hunger too often overcame their suspicions. Fionog-liàt himself could walk all round an iron gin and draw away the bait without springing the trap, and he could detect the poison in a "doctored " carcass as readily as he distinguished between the keeper and his gun and the herd with his stick; 


\section{WILD LIFE ON THE WING}

but the rest of the band were more rash, and time and again only the ceaseless vigilance of their leader saved their lives. While they fought over the sodden remains of rat or rabbit - the foxes' leavings-Fionog-liàt stood sentinel on some neighbouring tree, meanwhile imploring the gluttonous gang to follow him to the safety of the bogs. Once during such a feast, Driscoll crept near enough to wing one of the band, who was too heavily gorged to retreat as quickly as her fellows. They found the battered corpse next day and feasted hideously - all, that is, except Fionog-liàt, who hated a gun, and said so all day long until the rest of the band wearied of his warnings.

The cold red sunrise was generally the forerunner of a bleak day with an iron-coloured sky. Even when the wind veered a point or two the rain which fell was sleet, colder than the wind. Then the shoulders of the mountains were hidden under the driving skirts of the cloud, and their flanks were ribbed with the streaks of snow-dust which was swept into the lee of the rocks. But wind or snow, either meant starvation to the crows. They, who in times of plenty were wont to gorge to repletion and spend the following day in a pleasant lethargy of digestion, now went fasting for days together. Fionog-liàt took first toll of I I 8 


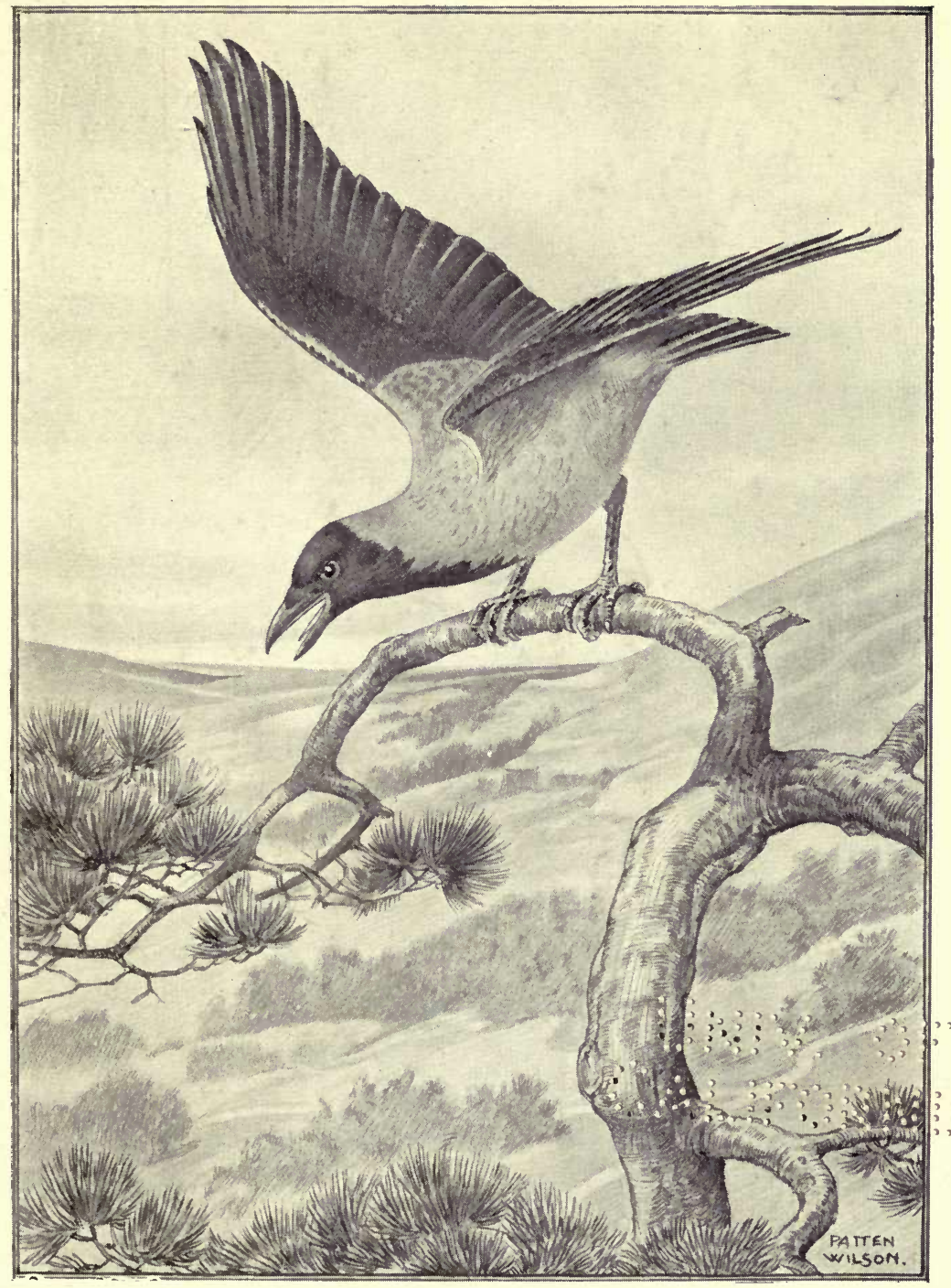

FIONOG-LIÀT WARNS HIS FOLLOWERS 



\section{THE HOODED CROW}

such food as they did find, for being the strongest and most savage of the band, he could often snatch a few morsels before the hunger of the rest drove out their fear of him, and they closed in round the quarry.

On one such afternoon after a heavy fall of snow, Fionog-liàt, beating up and down the

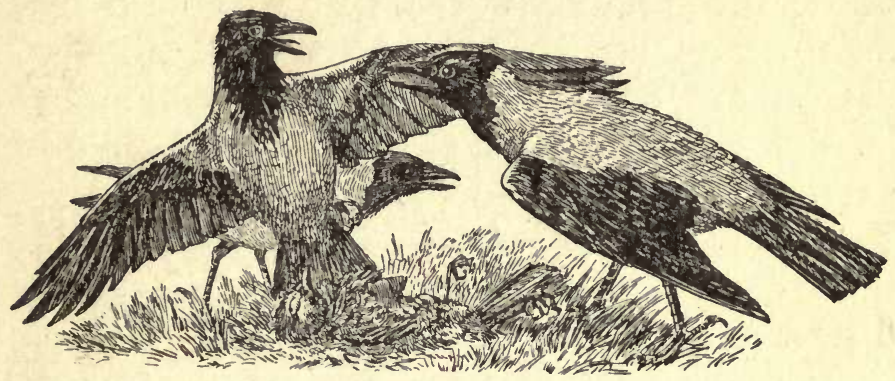

fields like a pointer, came upon a stain of fresh blood. Rubies were never a more welcome sight to a miser then were those crimson pits on the smooth snow to Fionog-liat of the pitiless hunger, and he alighted beside them eagerly. Though the trail was laid in blood it was strongly marked on the hillside, with three even prints, and in place of the fourth, a red stain-Geirr-fiäd the Hare, his mark, which he makes after that he has fallen among evil things in the lowlands, and escapes to the hills to die. Fionog-liàt saw that his next neighbour had seen him stoop, and was following him through 


\section{WILD LIFE ON THE WING}

the still cold air: the crows always kept one eye on their comrades' flight lest they themselves should be cheated of their share of the spoil. Fionog-liàt croaked, and flapped slowly up the slope towards the mountains, for farther on he had sighted an oblique smudge leading across a snowdrift, and there they picked up the trail. The snow was spattered with red, for the track was not half an hour old. Fionogliat pitched on to a neighbouring wall, and as he did so the two remaining crows flapped overhead, croaking in anticipation of food. They held a council on the wall, with the little thin wind from the mountains ruffling the feathers from their lean bodies. It was their leader who first spied a moving dot on the mountain above them, and all four
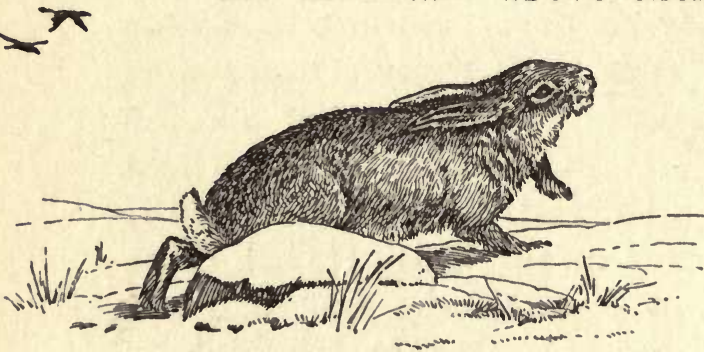

flew towards it. Where the fenced fields rise up the spurs of Commergar to meet the no-man'sland of rock and gorse and heather which covers his summit, the crows overtook Geirr-fiäd the Hare, who was plunging through the snowdrifts on three legs, with a raw red wound in 120 


\section{THE HOODED CROW}

his side. Fionog-liàt, flapping lazily against the wind a hundred feet away, noted with an experienced eye what strength and speed seemed to be left to the victim; but Geirr-fiäd, glancing up at the sinister shadow, flattened his ears and limped on the faster. Fionog-liat alighted unconcernedly on a rock, and his band followed his example. For many minutes the hillside was still and seemingly empty except for the labouring fugitive. Only now and then the hare heard one crow croak to another across the rocks, and knew that the keenest eyes from Kilcool to Knockbwee were upon him. Presently he laid down to pant, and immediately, with a rustle of wings, Fionogliàt alighted on a crag above him, and the rest of the band all clamoured jealously lest they should lose their share. Geirr-fiäd started up from the reddened snow, and limped on slowly, and again the crows sheered off reluctantly. The hillside was rough and bare, littered with great blocks of granite, between which tufts of heather and blechnum fern found a precarious root-hold. The hare knew the place well in the summer-time when the grass was sweet and green, and no one visited it but larks and mountain foxes. Commergar has a broad bosom : his children all return to him when hard pressed, and he seldom fails them. 


\section{WILD LIFE ON THE WING}

Three times within the next two hundred yards the hare lay down, but every time the rustle of the hunters' wings drove him on. The third time, Fionog-liat believed that his patience was to be rewarded, and sidled tentatively within a yard of the game; but at his step on the snow the hare dragged himself up and hurried on again with a white glint of fear in his upturned eyes. The crows flew away and circled over the Gap a quarter of a mile off, for Fionogliàt would not touch living meat.

So the slow chase went on. One crow gave it up, but the other two under the leadership of Fionog-liat waited for the end. The grey evening drew in. The crows grew bolder and more clamorous, but Geirr-fiäd still crawled along with blood on his tongue, struggling obliquely up the hill to ease his wounded leg. Fionogliat, fearing to lose his prey in the night, tried to hustle his victim and wear him out, but Geirr-fiäd, clinging desperately to life as the Fur Folk will though it has nothing to offer them but gangrene or starvation, stubbornly refused to lie down and die.

The sun set, and the bitter little wind hardened. Snow began to drive along the mountain-side in small pellets, which bounced from the rocks and sifted through the furze bushes, and darkness fell swiftly as it will on a stormy evening 


\section{THE HOODED CROW}

in December. At last the hare came face to face with a great boulder reared upon its end, and as he was too weak to climb over it, and the overhanging crag gave some protection against the blizzard, he crouched down under it, with his big frightened eyes fixed upon the waiting crows. Hungry as he was, Fionog-liàt dared not touch eyes as bright as those. It grew darker and darker, and still the band watched like wolves until the glimmer of life in their prey should be quenched; but every time Fionog-liat peered under the stone he met Geirr-fiäd's steady gaze. At last it was too dark to see the plover who swooped and wailed in the dim sky overhead, and Fionog-liat knew that they must wait no longer. Reluctantly he gave the signal, and with hoarse cries the three flapped wearily back to Kilcool, weak with hunger, the hard snow whipping their feathers.

At dawn the countryside was white, when after a preliminary flight over the wood Fionogliat turned to the bogs. Only two of his band followed him-those two young males who had hunted with him ever since he came to Kilcool. The keel of their breasts seemed almost pricking through their skins, and they were weak with famine, but their eyes were as fierce and cunning as ever. 


\section{WILD LIFE ON THE WING}

Fionog-liat flew as usual to the slopes of Commergar. The mountain was white except where it was gashed by crags to which no snow could cling, and the trail of yesterday's hunting was covered up. Fionog-liàt rose slowly up the hillside, and the other two crows, wheeling from a fruitless search in the bog, followed him. Suddenly they swooped, calling triumphantly. Under the stone the hare still crouched, with scarcely a heart-throb and his dim eyes half-closed. Fionog-liàt hopped forward to give the death-blow, but there was an eager rush of wings, and he was almost borne over by his followers who hurled themselves on to the carcass. At no other time would they have dared to oust him thus, but they were mad with hunger, and for the time being he was not their leader but their rival. On any other occasion they would have met with a buffet which would have driven them back cowed, but as it was Fionog-liat was too famished to resent the insult, and all three fell greedily upon the first full meal which they had eaten for six days.

They loitered round the place until nightfall. Now and then one descended to the rock for another morsel, but for the most part they huddled upon the crag, preening themselves languidly in the almost forgotten sensation of a 124 


\section{THE HOODED CROW}

full gorge. No other bird came near the place, for the bitter weather had driven most of the crow-kind to seek garbage on the sea-flats forty miles away, and in the evening when they returned to Kilcool they had the fir-tree almost to themselves.

But though the long wait and subsequent feast on the mountain had saved the lives of the crows for the time being, it struck a blow at Fionog-liàt's supremacy as leader. The younger birds had torn food unrebuked from under his bill, and they were not likely to forget it on the next occasion. That evening when Fionog-liàt dropped on to his usual roosting perch - the snuggest of all, be it saidhis claws gripped feathers instead of bark, and he found himself jammed shoulder to shoulder with his two mutinous followers. He jostled them straightway off the branch, and, complaining savagely, they sought a perch lower down; but Fionog-liat knew that such a thing would never have happened a week before. The crows passed the next day in leisurely idleness. After such a meal as theirs had been they did not feel the pinch of famine for many hours, but on the second day they were hungry again, and Fionog-liàt turned to the mountain. The two rebel birds followed him as far as the bogs, but then they bore away westwards on 


\section{WILD LIFE ON THE WING}

some foray of their own. However, two halfstarved birds, newly arrived from overseas, had joined the band, and these flying within hail of the leader accompanied him to the scene of the previous feast.

There was a pale luminous sun-spot in the southern sky, and whereas the wind had blown

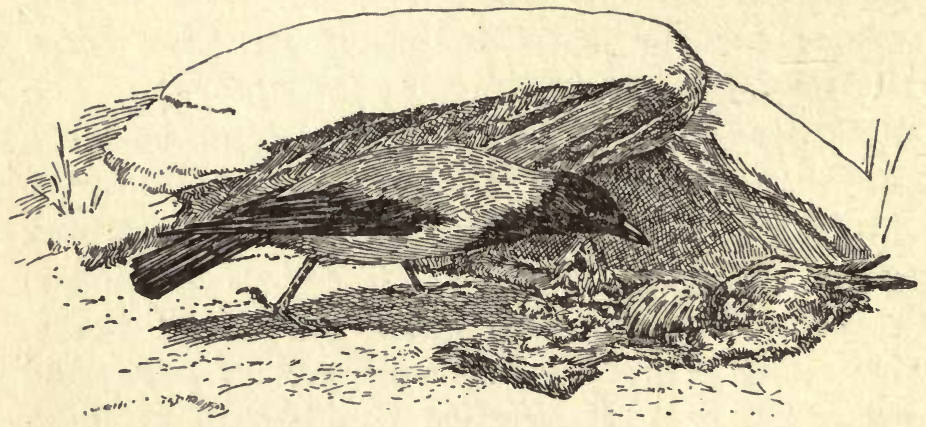

keenly through the Gap on the previous day, to-day there was no wind, and the smoke rose straight up in grey columns from the chimneys of Kilcool village. Commergar, the ridges of whose spurs had been swept bald by the wind during the preceding night, stood out black and grim against the white lowlands. As Fionog-liat rose to avoid an "air-pocket," a flock of teal passed high above him towards the north, and he croaked, for he knew that there was to be a change in the weather. What was left of their late banquet was littered I 26 


\section{THE HOODED CROW}

under the rock at the foot of the crag, and the pair of starving crows behind descended eagerly, but Fionog-liat looked at it with suspicion. The carcass was dragged out from where it had previously lain, and the surface of the snow was scarred all over with the broad smears of leather-shod feet. Moreover the paunch lay seductively in view, and Fionog-liàt knew that he himself had eaten the paunch two days before. He was a pessimist in his way, and therefore when an especial piece of good fortune-such as the sudden appearance of so much good meat-befell him, he was prone to suspect trickery. As we might read it in a printed book, so Fionog-liàt knew that all these things were Man, his mark : he distrusted the place, and said so. But the younger birds were less cautious, and they would have fallen ravenously upon the meat, if he had not driven them back with short barks and croaks of rage. As it was, they hirpled round the carcass, casting greedy sidelong glances at him as he stood over it ; and although they were weakly birds whom he generally bullied and chivvied where he would, he knew that they would never allow him to come between them and their food to-day.

Uneasily he tore out a piece of the meat. Truly it had a strange taste, but he was so 


\section{WILD LIFE ON THE WING}

hungry that he could not forbear a second morsel. There was no doubt - the taint of men lay upon it. Fionog-liat flew to the head of the crag and cried to his followers to bid them beware; but he spoke to deaf ears, for they were too busy stripping the bones of what little meat remained on them to listen to his

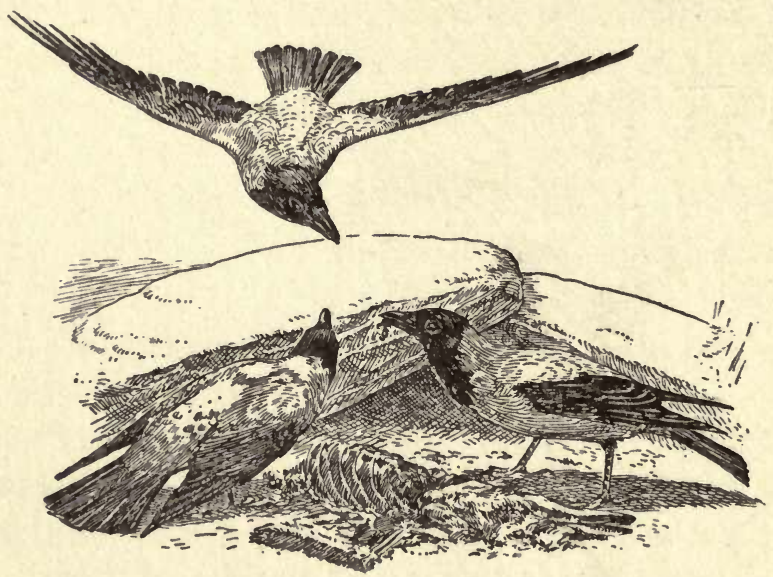

warning. "Fools-fools!" cried Fionog-liàt, and soared out over the Gap to tempt them to follow him to a safer repast; but they only squabbled together, and snatched tit-bits from each other's bills until there was scarcely anything left. If Fionog-liàt had been younger and less wise, he would not have been able to resist the hunger pain ; as it was, his long experience had taught him that above all Man I 28 


\section{THE HOODED CROW}

and his works - traps, guns and poisoned baits - must be avoided. Therefore although the temptation was so strong that several times he flew down to the food, yet he always overcame it, and returned to his perch without tasting.

In three minutes the young crows had devoured all that they could find, and then, calling loudly, the three birds flew slowly away. ... He who had eaten most fully of the poisoned paunch succumbed first. Before he had flown a hundred yards, he whirled earthwards with his wings set rigid-a dead bundle of feathers. Fionog-liàt swooped after him, as the deep heather swallowed him up, then rose distrustfully, for there was something uncanny about the way he fell.

The second bird flew on unsteadily for some twenty perches distance, then slanted down to the mountain-side with the call choked in his throat. He stood for a minute or two with heaving wings and gaping bill, and then the subtle poison did its work swiftly.

Fionog-liat found himself alone. He flew round, calling to his band as he called them in the woods at daybreak to summon them to a foray ; but there was no reply but the melancholy pipe of the golden plover, and nothing stirred on the hill. Suddenly he swooped down to the crag. A sickness more awful than that 


\section{WILD LIFE ON THE WING}

of hunger seized him all at once. The rocks, the snow and the heather seemed to swim and heave together: he huddled down with halfclosed eyes while shuddering spasms racked him.

* $\quad$ * $\quad$ * $\quad$ *

A tentative croak close at hand aroused him. One of his two mutinous followers was eyeing him intently. He tried to give his usual call note, but his throat was constricted, and as he launched himself into the air, his wings were so stiff and powerless that he parachuted awkwardly on to the rock below. There was a rustle of wings, and the second rebel alighted near by -attracted like his fellow by their leader's great voice as he called up his other unfortunate followers from their fatal repast. Glancing mistrustfully at Fionog-liat, they began to search for fragments of meat, but nothing remained but a few bones and pieces of skin. However, one of them presently spied a small portion of the entrail which had been tossed unobserved under a rock, and he began to sidle up to it with cunning furtive looks. What then impelled the leader to act as he did, I cannot say. James Driscoll, who laid the bait and who told me the story, said : "Begor', me gran'lad stood over the mate what way the rest o' the craythers wouldn't get a bite at all, 


\section{THE HOODED CROW}

for he was as sour wid them as a bag o' ferrets"; and probably James was right. But whether it was indeed jealousy of his rights as leader, or else, in some strange way, his care for the rest of his band which impelled him, the fact remains that just as the other bird craned his neck for the morsel, Fionog-liat dropped from his perch, and he himself swallowed the poisoned meat at a gulp.

For a minute the other two birds stood glaring at him, as they saw the coveted morsel disappear before their eyes. If they had not known the weight and readiness of their leader's thrashing wing, they would have fallen upon him there and then, but sick or well Fionogliàt was not an antagonist to be despised. Even while they hesitated his wrath blazed up, and he turned upon them; but his limbs refused his bidding, and he flapped an impotent travesty of the headlong punitive rush which he had intended to make. Nevertheless it served its purpose, for the two crows took alarm at his contortions and sheered off.

Fionog-liàt was left alone. How long he stood there he did not know, for he lost all reckoning of everything. If the keeper had come along then, he might have knocked him over without a flutter. If the poison had been evenly distributed through the bait, Fionog-liat 


\section{WILD LIFE ON THE WING}

would have fallen down stark and stiff as the pair who lay among the heather at the foot of the crag, but, as it happened, that particular piece of meat had been less thoroughly "doctored" than the rest. It takes much poison to kill a hardy scaulcrow, or as James Driscoll put it-" the divil has an eye to his own," and although at one time it looked as though Fionog-liat would never suck peewits' eggs again, yet the life-flame burnt hardily in him, and he did not die.

When he struggled slowly back from that dim land of unconsciousness where nothing is real but pain, and there is no desire but for peace, the sky was no longer a grey emptiness, but was laden with rain, and only two or three hours were left to the winter's day. At first Fionog-liàt believed that he was alone with the rocks and the clouds, but as his senses reeled back to him he became aware that he was watched. One crow was perched on the rock above him; the other, on the snow, was nearer still. He felt their eyes upon him, and knew that they were watching him just as he himself had watched the hare two days before. They were starving as he had starved then, and just as he had fidgeted impatiently up and down so they waited now. He had saved them from the man's poison-he himself had devoured the 


\section{THE HOODED CROW}

last morsel-and now they were waiting for it to complete its work in him. There was nothing else in the whole countryside left for them to eat. So much he saw, and then another paroxysm seized him. When it passed off, and he could see clearly again, both crows were standing a little distance away, preening their feathers unconcernedly. But their tracks showed how they had walked round and round him, trying to summon up courage to deal the death-blow; and there was a long smear where the wing of the bolder of the two had flicked the snow as he bounced aside startled when his intended victim's eyes opened.

Thus they watched him for an hour, while the life in him fought a tough battle with the poison, and slowly conquered it. Every time that he closed his eyes he heard his persecutors hop stealthily nearer, and he dared not relax his vigilance for more than a minute at a time lest they should rush upon him and take him unawares. A loathing of them and their silent impatience seized him-something of the same horror which had driven Geirr-fiäd the Hare up the mountain long after his strength was spent. He broke away from them suddenly, half-hopping, half-flying among the rocks. The crows followed eagerly: they had seen the game start in such despairing panic before. 


\section{WILLD LIFE ON THE WING}

Often it was the beginning of the end, and they waited for him to fall from exhaustion and give them the opportunity to deal a death-blow.

It was near nightfall-one by one lights appeared in the cottages in the lowlands, and the snowdrifts stood out startlingly white against the leaden sky. But as Fionog-liat fled with the fear of death behind him, slowly but surely his strength returned, and with it his hardihood. His limbs were still feeble, but he could control them; his heart throbbed more steadily, and his voice came back to him. The west wind, with a promise of rain, blew against the crag. He spread his wings against it, and soared thirty feet up. As a tide retreats sullenly from the beaches, so the clutch of the poison at his throat relaxed, and he gave the old rallying call to his band. And although a minute before he had been their last resource against starvation, they recognized it. Only for a moment did they hesitate. Then by all the laws of the crow-breed he became their leader once more, to be feared and hated perhaps, but none the less to be obeyed. With answering clamour, they rose sedately, still weak with famine, but once more under their leader's rule, and all three winged their way slowly through the dusk to the woods.

* * * * * * *




\section{THE HOODED CROW}

All that night the old fir-tree swayed and dripped in the storm, and at dawn pools of water stood in hollows which the parching winds had licked dry. But James Driscoll, crossing the bogs to the mountain at noon, saw nothing of Fionog-liat and his marauders, for overhead the cloud-wreaths still scurried fast before the brave sou'-wester-the sou'-wester which carries warm rain in thaw, the sou'wester which blows into the East-country. 


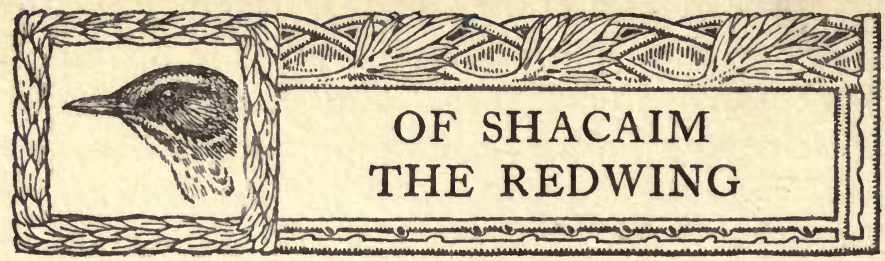

I

For three days, the north wind blew. Then it shifted a few points to the east, and in the morning watch the snow came. When the tardy dawn broke, it was not so much the arrival of day as the passing of night; and what light there was arose, not so much from the grey sky, or from the greyer sea, but from the earth, already whitened in the hollows. And before the darkness had lifted sufficiently to let a man tell the curdled foam on the beach from the snow which it licked, the birds began to come over from Wales. A flock of curlew, flying high to the sou'-west, began the stream, and it continued without intermission until noon. Larks, worn with buffeting for hours with snow and wind, perched thankfully upon the frozen beach, too exhausted to struggle a few yards farther on into the shelter of the bent grass; and pipits toddled weakly over the shingle, or crouched behind pebbles with I 36 


\section{THE REDW ING}

the snow pellets leaping from their feathers. Fieldfares in regiments two hundred strong, slanted over the sandhills. Cock blackbirds in dozens also came in; and famine-stricken as they were, they were stronger than the stormbeaten throstles, who fluttered ashore only a few feet above the waves. On the sandhills among the buckthorn bushes, tired woodcock squatted, with the bones pricking through their skin; and redwings lay with sand and snow sifting over their plumage. On the leeward side of a hillock sat an exhausted jack-snipe with his long bill laid out on the snow; and a quartet of ringed plover, hardy and strong-flighted though they were, had been driven from the bleak seashore to the comparative shelter of the dunes, and stood head to wind upon a frozen hummock. Starlings, thousands of them, flew in, straight-flighted and still fresh, all wheeling promptly as the leader rose or dipped. Compared to the straggling ranks of the thrushes, they were as trained bands are to irregular levies-both may start the march in order, but in the rout discipline will tell. And this was a rout - a defeat; when the birds fled south in tumultuous confusion, with the north wind howling behind them: a rout where the weaklings dropped out and died by the way.

The redwings drifted over in parties of from 


\section{WILD LIFE ON THE WING}

twenty to two hundred birds, bewildered, weary. They huddled in what shelter they might, and only chirped querulously when some stronger arrival thrust them out into the wind. And over all passed a ceaseless stream of plover. As far as eye could see they spangled the sky. They came as it were in successive waves, each wave of some two hundred peewits, extending for miles along the coast; and in the rifts between, the golden plover-swiftest thing which flies-dashed by, heading towards the granite-crowned brow of Moyle Hill. In stormy weather Moyle is the landmark by which the Feather Folk take their bearings.

To seaward the wind whipped the tops of the waves in to foam. The air was awhirl with dancing snowflakes which stung cruelly cold, and hissed when they touched the water. How many throbbing breasts were stilled in the stormy Channel that dawn only the Channel knows, for the sea claims a heavy toll when the Feather Folk travel. At nine o'clock more redwings came in-perhaps a hundred birds. Twice that number had left Wales, but the rest had gone astray. In that flock-one among many such flocks-was a bird, a unit among the starving hordes on the Coolnabrock sandhills, but, such as it was, his subsequent history was known to the human chronicler, and shall be duly set out. I $3^{8}$ 


\section{THE RE D W ING}

He came from a Norwegian forest, and when he left his birthland, or what his previous adventures may have been, the chronicler does not know. To all intents and purposes his story begins when he crossed the Irish Channel that stormy morning, and, like the Three Children, taking a new name in a strange land, became Shacaim, the frost-thrush, of Coolnabrock.

With his fellows he dropped gratefully to the shelter of the sandhills, and there for the first time in his life he saw the sea-buckthorns in fruit. As far as his eye could pierce through the driving snow, the hillocks were clothed with the shrubs which glowed like live coals. Each twig was weighed down with a freight of orange berries, and to every available space, screaming, gobbling, fighting, clung birds. The tops of the bushes bent under garlands of fieldfares ; misselthrushes fought for standing room upon their fellows' shoulders, while scores of finches stripped the lower twigs. The redwing, fighting like the rest, pitched on to a bush and gobbled thankfully. The berries were acrid, but they filled his empty crop, and that was all he asked. Just below him, a hungry moorhen lurched from bough to bough ; above, half a dozen stolid greenfinches smashed the berries, and spattered their neighbours with the yellow juice. Farther on, half a score of mag- 


\section{WILD LIFE ON THE WING}

pies passed through the bushes, and the chaffinches were now so eager that they scarcely troubled to scold, as was their custom, as the pies pushed past them. The redwing squabbled and jostled with the rest until his crop was full, and then he huddled on a twig and languidly preened himself.

At noon the sky cleared, and with the snow the bird stream ceased.

Then the great march inland began. Shacaim, with some of his clan, crossed the rush-grown stream which creeps along at the foot of the sandhills, and beyond which lie the deep woods and mellow pastures of Coolnabrock. But it was no land of promise that winter's day. First of all they found low sycamoresdreariest of all trees in rain or snow. Their drab leaves covered the ground, and snow clung to the leeward side of their trunks. They were utterly empty but for a hungry robin or two. However, the redwings kept on, for the stronger-flighted fieldfares flew steadily over the trees as if they sighted something better ahead. Besides, there was no going back. The sea lay behind, and the wind still blew inland. Perforce they went on.

By and by the sycamores merged into oaks, I 40 


\section{THE REDWING}

under which grew briar and privet. The rain and frost had left no greenery on either, but they gave a semblance of shelter, and the birds settled in them gratefully. The snow lay an inch deep in all the clearings, and the native Fur and Feather Folk had already begun to shift their quarters as is their custom in sudden calamities such as flood, snow or drought. Bullfinches, cheeping drearily, left the privet thickets where they had passed the lotus days of October : woodpigeons, wholly bewildered, clattered in and out of the trees: the rabbit trails wove lacy patterns in the rides and clearings.

Meanwhile the western clouds were cloven, and the greenish sky gave promise of frost. The rooks, empty cropped for the most part, flapped homewards in three great armies-north from Ballinakill, south from Moyle, and east from Coolachiel; and among their sober ranks, like mosquitoes among bees, buzzed hordes of noisy wheezing starlings.

The hungrier the Feather Folk may be, the more loudly will they declaim the fact to the woods at roosting-time. Londub the Blackbird protested vigorously when a bunch of starlings bounced into his bush; and every starling tried half a dozen perches before he was suited, explaining volubly to the world, meanwhile, why each

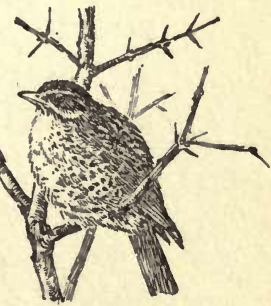




\section{WILD LIFE ON THE WING}

was unsuitable. The redwing selected a leafless thorn-tree, and huddled there in silence. In size and manners Shacaim is a very thrushthe buff phylactery over either brow, and the rusty stain under the wing hall-mark him as apart from the throstle ; but he has the throstle's lack of assertion and love of secret, leaf-strewn places. Therefore he only chirped in feeble expostulation when he was jostled off his perch, and he and his kind added little to the clamour of the woods. Even when the sunset reflections had faded, and the vast silence of fallen snow settled on the countryside, the birds still kept up a drowsy undercurrent of recrimination, for perches were at a premium in Coolnabrock that night.

The multitude woke at dawn, but there was no rest for them. The snow was firmly welded to the branches, and there was no grass to be seen. The misselthrushes went out to the open country to join the fieldfares in the haw hedges, but the redwings remained in the woods, for berries were not so much to their liking as insect food. Shacaim followed the river where it winds among barren jungles of woodrush and rhododendron, until he came to a little stream which broke the bank under an oak-tree. It flowed from a tangle of brambles and woolly clematis; and because a redwing dearly loves 142 
the sound of running water, he followed it through thickets of briar, bamboo, berberis and yew, a garden of man's and nature's joint planting. Then just where the free wood began to predominate again, he came to the elders. The elder thicket is one of the few places in Coolnabrock which men have not yet hallmarked with bill-hook, and axe-there is no path, and the brittle stems are interlaced so closely, breast high, that neither man nor horse can crash through them. It is the sanctuary of the Feather Folk. How many a woodcock has swung out of a fern tuft and heard the tardy shot zip away the twigs below his tail, as the sportsman brings up his gun through the kindly hampering branches? How many a pigeon has clattered out on the thitherward side of the thicket, at the timely crack of a twig under the approaching keeper's foot? And then in autumn, when the leaves begin to blanch, the bushes are hung with juicy mop-heads of berries-the Feather Folk all know the eldersthrush, pheasant, pigeon, and Seabac the Blue Hawk. Now the leaves had fallen, and the berries were all pulled; but the stream, which ran too fast for any frost to bind, fell tinkling from one leaf-dammed basin to another, and on the farther bank grew holly, best of all covert for thrushes. Shacaim, from a beech-tree, saw 


\section{WILD LIFE ON THE WING}

that the place was pleasant, and noting the nakedness of the land beyond, descended to the streamside to drink. It was a little oasis in the emptiness of the woods, and was full of pilgrims. A pair of squirrels dug for rotting nuts, and a thin woodcock squatted under a fern stub where at least it was dry. The blackbirds turned over each leaf repeatedly; Breac au Tril the Chaffinch, and Colm coille the Pigeon ransacked the tree-roots for beech mast ; and-surest mark of stress of weather-a couple of white-rumped bramblings helped them.

Shacaim, with three of his fellows, rested there for four days - and all that while the frost never broke. By day the redwings, each in his own little plot, turned over the leaves industriously in search of food which they could not find: by night they roosted among the hollies on perches rough with ice. On the fifth day they departed. As though at a given signal, one by one, they quietly left the place and went inland.

That night they roosted, heads to wind, in the hedges, and by dawn their toes were frozen to the bark. The redwings went into the fields and followed the cattle. Where a bullock had lain all night, the snow melted, and the sodden grass held possibilities-a torpid snail or hibernating grub. All day a grey mist hung about I 44 


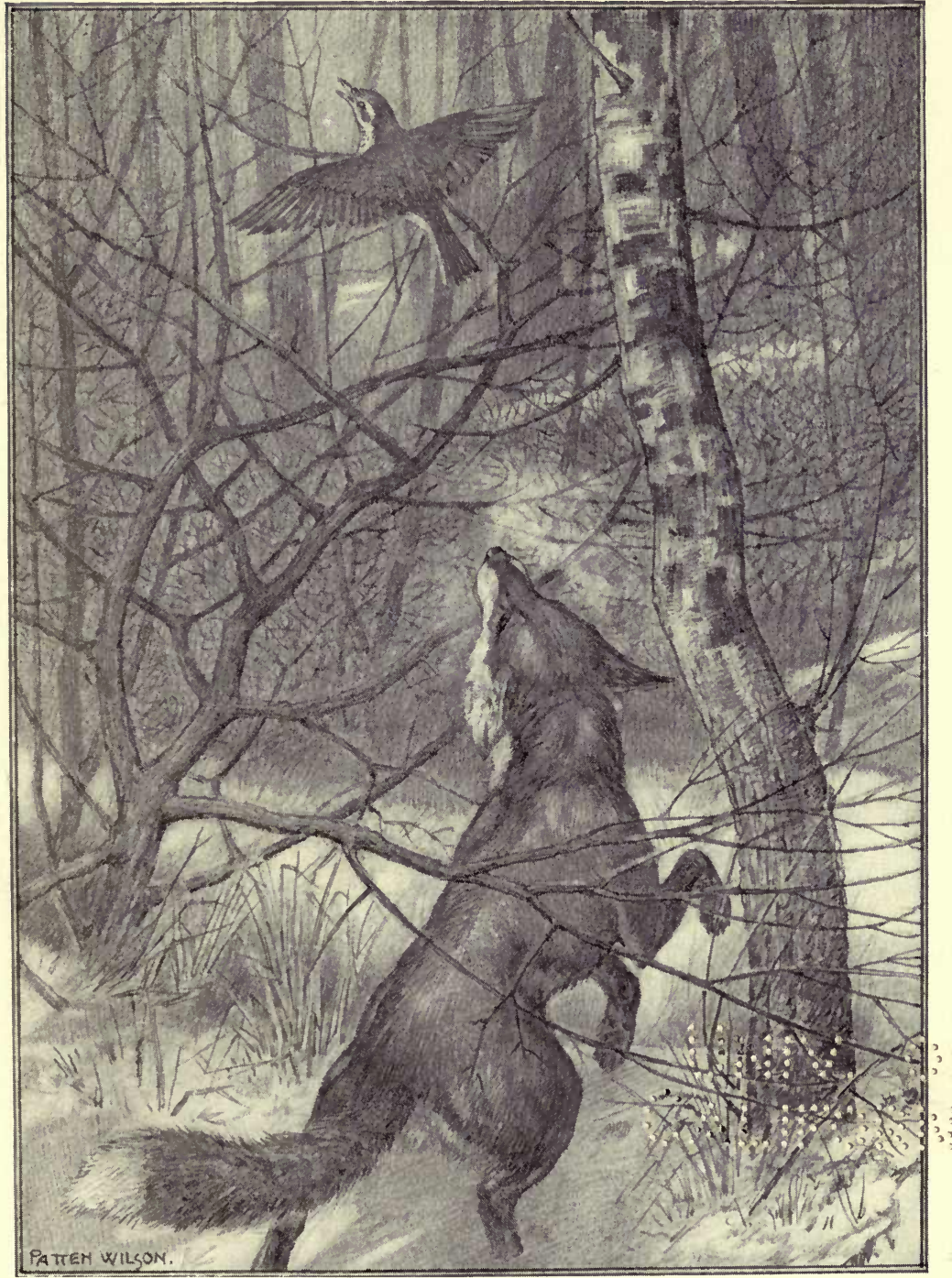

\section{SHACAIM DASHED OUT}





\section{THE REDWING}

the shadows of the woods, and at noon the sun gleamed weakly through the clouds. The Feather Folk are sure weather prophets-they knew that a thaw was coming. The wild duck wandered from stream to pool to see whether the ice was melted yet, and Pillibeen the Plover and his brothers went north in thousands.

Just across the fields was a little copse-and that night the birds roosted there in hundreds. The winter night is eight hours longer than that of midsummer, and the Feather Folk sleep through either, from dusk to dawn, as it is ordained for them ; nevertheless, in January they dream and wake more often than in June. Hence, near midnight, the patter of feet tiptoeing down the little path towards Coolnabrock, broke in upon the redwing's dreams. Chirping fitfully he drew his bill from his back feathers. A light breath was taken in the darkness underneath the bush, and the stem was jarred ever so slightly. The redwing was suspicious and hopped two twigs higher. Suddenly something heaved up, and there was the click of disappointed jaws snapping under his tail, as the fox hurled himself into the bush, and slithered back amid a crashing of twigs. Shacaim dashed out, and at his alarm note the copse sprang into rushing beating life. Blackbird, throstle, redwing, all panic-spurred, 


\section{WILD LIFE ON THE WING}

fluttered and jostled. "Fox! fox!" gabbled a frantic blackbird, and the retreat of the marauder was marked by a fresh hurricane of wings. In his bewilderment, Shacaim forgot the geography of the branches. He felt the

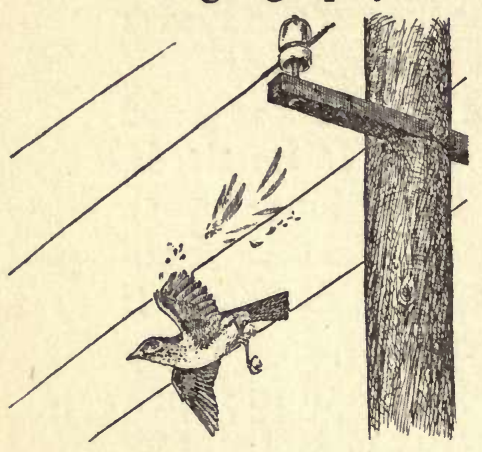

buzz of the rising starling hordes - their battalions outflanked him on either side, and the draught of their turning sucked him down. He slanted-thirty miles an hour - towards the road beneath him. There was a twang as some unwary starling blundered against the telegraph wires-Shacaim had forgotten them, but it was too late to turn-he struck them fairly, with a crash-then whirling over and over, a limp wisp of feathers, fell into the road.

\section{II}

The mild dawn broke in rain, and drops from the trees overhead splashed into puddles in the road. Shacaim crouched under a grass tuft by the hedge. His heart beat like a piston, and his bill gaped. $\mathrm{He}$ was desperately afraid. He saw the glimmer of the "false dawn" melt 146 


\section{THE REDWING}

into the full colour of day. Belated rabbits, ghost-like, paddled across the road; the scaulcrows down the wood cried aloud for joy of the thaw, and the rookery answered in clamorous jubilee. The birds of the thicket went out to feed, but even the bustle of their departing did not rouse the redwing; and he was still there half an hour later when the magpie dropped with a flourish, and promenaded across the road, eyeing him sidelong. Sharp eyes has the magpie-sharp as his beak-and the glint of them woke the redwing out of his bemusement with a thrill, full of solicitude for his own. Things rocked back to their proper proportions in his mind, as the magpie shuffled his daggerbill nearer-Shacaim fluttered from his tussock with trailing wing, and sprang up the hedgebank-but to his surprise he somersaulted lopsidedly into the ditch. The magpie departed with a frightened squawk, but Shacaim on the mud gasped with a larger terror. $\mathrm{He}$ had forgotten how to fly. Wild-eyed, he tried again. The utmost he could attain to was a shuffling hop, with his wings outstretched as balancers. His wing was clipped as neatly as if human hands had done it, for the telegraph wire, shearing through the carpal joint, had carried away the strong flying quills-he would never fly again. 


\section{WILD LIFE ON THE WING}

$\mathrm{He}$ did not realize this of course, but in his pitiful dumb fashion he knew that all was not well with him, and, in accordance with the law of the Wild, he crept away from the cold glare of the sky into the wet woods.

There busy blackbirds turned over the dead leaves under the oak-trees. Now and again, as cat or hawk passed on his beat, one would fly up with a low chuckle, and his fellows for twenty yards round would take the alarm and, rising, pass on the signal. The first time Shacaim sprang up with the rest, but immediately tumbled back panting on to the moss. "Chinkchink!" shrilled a blackbird higher up the wood. The whisker-guarded face of a cat was thrust delicately round a fern stub. Under the stare of the golden eyes the redwing collapsed, gasping. The cat twitched her tail and slid forward, but in so doing she stepped upon a dry twig. A small happening, but it saved the redwing, for the free end was pushed against his breast and roused him. He fluttered away, but the cat, padding softly after him, struck like a boxer, but too late to catch anything but the draught of wings and a feather. Shacaim fluttered desperately towards the hedge. Oncetwice the spread claws behind almost caught him, but, with the cunning of fear, each time he interposed a tree trunk between himself and 148 


\section{THE REDW ING}

his pursuer. The blackbirds in the branches overhead "chink-chinked" lustily, and now and then one bolder than the rest dashed down upon the cat, and won for the fugitive a moment's breathing space. Suddenly the ground fell away before him, and, with a last effort, he struggled across the ditch into the hedge. Here he was comparatively safe, for he could slip mouse-like through thorns which the cat could not pass. The latter realized this, and licking her chops, retired into the wood, chatter of blackbird and clamour of finch marking her retreat.

That was how Shacaim learned that although manifold perils beset the ways of the birds, they are as nothing compared to those which lurk round the earth-bound paths of the Fur Folk, whose vicissitudes he was henceforward to share. This lesson was brought home to him at noon, when a stoat came hunting through the bramble bushes, and drove him palpitating into the temporary security of the hedge : and he learned it again in the evening when he reencountered the cat watching the privet bushes where the chaffinches go to roost. As for the Fur Folk themselves, they take in this lesson with their mother's milk.

* * * * * * *

On the third day, Shacaim found himself in 
WILD LIFE ON THE WING

Ballymoney Glen. It was not far from the scene of his accident, but to reach it he had run the gauntlet of many perils - the open field, the brook, and the gorse covert. It was a sweet February afternoon, whose sunshine looked, even if it did not feel, warm. The arum leaves had burrowed upwards into the light, and the succulent tufts of the ransoms were green in the shady places. The throstles, whose throats had been choked by the hunger pain of the cold snap, sang again, and the misselthrushes were quarrelsome and noisy. It was Spring. Shacaim twittered and shuffled his maimed wing. With the marvellous power of the Wild Folk, he had already adapted his way of life to his altered circumstances, and his wound was on a fair way to be healed, as, indeed, such a clean cut was bound to do. His plumage was preened as sleekly as usual-not a feather lay awry on his spotted waistcoat. Of course he was not accustomed to run like a pheasant or water-hen, and at the first, the strain upon his legs troubled him, for whenever they grew weary, by force of habit he launched himself into the air and tumbled headlong to earth again. Once or twice this mistake almost cost him dear, for it drew upon him the attention of enemies who would otherwise have passed him by. It was thus that the yellow hen found him, and she clucked up her 150 


\section{THE REDWING}

clan who were turning over the dead leaves. When he fluttered, they thought that he was trapped, and clustered round, staring at him with stupid curiosity, but when he recollected himself, they lost interest in him and pottered away.

Thus Shacaim met the fowls. What attracted him at once, was their marvellous power of scratching. Their strong feet struck down easily to depths of mould to which his own feeble perching claws could not reach. Two scrapes, and behold a foot of earth with its treasures laid bare. He humbly hop-stepped after these lordly birds all the afternoon, and fed gratefully upon such trifles as they overlooked.

When the sunshine left the undergrowth, and mounted the higher branches, before disappearing into the golden sky, the chickens turned up the Glen ; and for the sake of companionship the redwing followed them. They conversed in low contented tones, and loitered desultorily among the saplings. The wood grew more open-one could see the sky between the treetrunks. Suddenly a strange voice, raucous and penetrating, broke the peace of the wood. The fowls began to run like water-rails, and their rush bore Shacaim into the hedge, where he hid himself. But the fowls had no doubts. 


\section{WILD LIFE ON THE WING}

From the other side of the hedge came mysterious scuffling, squawking, chuckling. There were others of the Feather Folk waiting above the place-tits, chaffinches, and a daw or two. He tripped over the leaves and peeped into the cabbage-garden of Mrs. Maguire. Mrs. Maguire was feeding her "fowl" on stirabout. Shacaim had learned more of human folk during the winter than in all the previous months in Norway, and knew that they were to be avoided; but the slow swing of Mrs. Maguire's petticoats inspired him with less awe than did the generality of her kind. She had lived in Ballymoney Glen for twenty years, with the trees of the wood over her roof, and the birds of the air looking in at her doorway; and perhaps those who live thus, acquire a certain affinity to the wild which others miss. The fowls fought round her feet-a bumptious robin snapped up a crumb from between her cracked boots, and the chaffinches dodged about on the outskirts of the crowd. The redwing noted how the fowls, crop-filled and drowsy, strolled off to the cottage, where they slept in the chimney-corner opposite Mrs. Maguire's own bed. Then, with the wild Feather Folk, he fed upon the remnants of their meal, before turning to roost in the hedge beside the house. The smell of man lay about the place-a smell 


\section{THE REDWING}

which fox and stoat would respect-it was a harbourage.

But two hours later, he woke up. It is only human beings who believe that there is no light at night without open moon and stars. Not twenty nights in the year are " pitch dark." This night was faintly starlit, and the owl who swooped by, found it an eminently desirable hunting night. But it was not the owl which made Shacaim's heart beat "thit-thud," but a certain stir among the cabbages. He heard the snuffling of many noses, and caught the glint of little eyes-not of one pair or two, but of dozens. As his irides widened, he made out more, bloodthirsty, stealthy, peering from holes in the banks, creeping down the cabbage-rows, trampling the path where the poultry fed. From the bottom of the garden came the measured "plop-plop" of a love-sick frog travelling towards the Mecca of his people in the pond over the road. Suddenly it ceased, and instead came a piteous minor cry, as if sharp teeth closing upon his soft sides wrung it from him. The army in the cabbages flung up their heads, and sniffed. Shacaim's blood chilled, and unconsciously he chirruped with fear. Instantly innumerable eyes turned upon him, innumerable tails stirred, innumerable paws pattered towards the hedge. ... Shacaim 


\section{WILD LIFE ON THE WING}

threw himself into the darkness, and beat himself against thorns in his flight. He believed that the whole rat regiment was upon him. The harbourage was no harbourage-he fled back to the wood.

Morning was golden and windy. Wreaths of white mist fled to the nor'-west. The bucket without a bottom which served Mrs. Maguire for a chimney was blown askew. She and her hens came out of the cottage together, and she fed them as she had done the night before. Shacaim saw them. Dawn found him still in the hedge-rats there might be in that garden, but there was also food. He waited, and as before the yellow-legged fowls fed, and then, while they enjoyed a dust-bath by the hedgeside, Shacaim went down and breakfasted.

On one side of the cabbage-patch was the bank where the rat colony lived; on the other two was a straggling hedge which abutted on the wood. So many fowls had passed through it, that it was nothing but a series of run-ways, arched over by naked blackthorns. In the middle of the hedge flanked by two ivied thorns was a gap, which Mrs. Maguire had stopped with a skeogh. Beyond this, was a clearing in the wood where, after rain, water lay an inch deep on the dead leaves, and here the redwing, later, hunted industriously for drowned worms. I 54 


\section{THE REDWING}

One of the thorn-trees was cased in, and distorted by hairy ivy arms. At its roots these, arching, had formed a little cave which some bygone rat had mined into a twelve-inch shaft. Shacaim found it out on the first day, and for that night, and for many afterwards, he roosted inside, out of sight of the rats.

The cabbage-patch nominally belonged to Mrs. Maguire, but actually to Spideogue the Robin. Spideogue never left the cabbage-patch, even to go into the wood. He roosted in the ivied tree by the skeogh (a storey above the redwing). He fed with the hens, and kept the cabbage-beds and the paths scrupulously free from worms. By day he patrolled his domain up and down, and if a stranger entered, Spideogue abused him at sight. In fact, one might well believe that Spideogue regretted the coming of night, because he was then obliged to go to roost, and leave the rats in possession of his cabbages. For the first three days of Shacaim's sojourn by the cabin in the Glen, Spideogue abused him every time that he saw him slip through the hedge, and at mealtimes jostled him aside to snatch food from under his timid bill ; but gradually he became accustomed to this addition to the ranks of his fellow-pensioners, and bullied him less unduly.

There were many thrushes and blackbirds in 


\section{WILD LIFE ON THE WING}

the glen, and in stormy weather, flights of the redwing kind, but the latter seldom came to earth. They perched twittering in some treetop and Shacaim would pause in his pupahunting to watch them. Sometimes he tried to join them, but generally, long before he came up with them, with a rush of wings and flash of red under-coverts, they returned to the open country whither he could not follow them. I do not know whether his loneliness grieved him as human beings understand grief, but I think that he must have felt dimly that something was lacking to him; for Robinson Crusoe on his island was not more solitary than he, bound to this corner of the woods, and cut off from all communion with his kind. The brain of a bird (and in less measure that of a beast) is a tilting-ground for conflicting instincts. These instincts also battle in the human brain, but here the referee-the consciousness-steps in to order their tournament. In the woods the strongest instinct wins; and although after such a glimpse the redwing became restless for a while, yet very soon the more insistent need for food or self-preservation drove out the weaker desire for fellowship. 


\section{THE REDW ING}

\section{III}

The celandines faded, and their places were taken by anemones and alehoof. The elmtree's red buds came on apace, and the willows were tasselled with gold. The chattering "clack" of the fieldfares was never heard now, and the throstles and blackbirds were in full song. Lovesick wood-pigeons flapped in and out of the ash-trees, and three primroses opened where February had only seen one. Every forenoon a throstle worked industriously at her nest in the hedge, and one morning a chiffchaff piped windily up the glen.

Shacaim was still a pensioner on the bounty of Mrs. Maguire and her hens. Although his wounded wing had healed completely, and he had learned to run as swiftly and as silently as a corncrake, yet his powers of flight were gone irredeemably, and he could not have left the Glen even had he wished. Night after night he roosted in the cave among the ivy roots, and its dusty floor was patted hard by his claws. Here he was safe when the rats came out after dark. They had well-trampled paths through the cabbages, but they seldom came as far as the hedge. Which was well for Shacaim, for many litters were born in the bank that spring, and the parents were hungry. 


\section{WILD LIFE ON THE WING}

Mrs. Maguire herself he learned to treat with indifference. When the fowls trespassed too blatantly in her kitchen, she drove them out helter-skelter, and pelted them with potatoskins; otherwise the birds, wild or tame, took no more notice of her than of the crumbling mud walls of the cottage.

So March went shouting out with the jubilee of the equinoctial gales, and April, windy and sunny, came to the Glen. Then the last redwings left for the north. One day a flock, perhaps twenty strong, passed the day in the field near the cottage. Shacaim heard them, and left the fowls in the wood. The other birds took no notice of him as he slipped timidly through the hedge and joined them. They ran restlessly here and there, merely pretending to eat, for the stirrings of the flight impulse worked in them, and with the weather the Feather Folk change their ways. In the new satisfaction of fellowship Shacaim ran from grass tuft to grass tuft as nimbly as any of them. As the sun dipped, Mrs. Maguire came out and called her hens to be fed, but he had forgotten all about the fowls.

Seabac the Sparrow-hawk from Coolnabrock, came up the Glen on his evening "beat." The outermost bird of the redwing company marked him, and rose, calling softly. The next redI 58 
wing passed on the word, till one by one the whole flock headed for the safety of the trees. That is, all but the crippled bird. An hour passed in the company of his kind, and old instincts had awakened as strongly as ever. Not for many days had he tried to fly, but under the rustle of his brothers' rising, the lessons which necessity had taught him all these weeks were obliterated, and he sprang up, wings outspread. The green field rose swiftly up to meet him, and he fell back on to the grass. Nothing daunted, he began to run. Had he known it, it would have been wiser to have squatted where he fell among the clods. As it was, the hawk spied him, and wheeled up wind. Shacaim heard the swish of the stiffened wings as his pursuer stooped to strike, then the talons gripped him across the thighs, clutching to the bone. The hawk rose laboriously with his quarry. The grass spun away beneath them. . . They rose above the cabbages, above the cabin ... even above the smoke wreath, to the level of the great ash fork. Then the hawk's hold slipped, and he shot skywards, suddenly lightened, with his claws full of feathers. Shacaim parachuted dizzily earthwards. Seabac dived sheer down after his prey like a swallow, but he stooped just too late, for his victim had fluttered down to the feet of Mrs. Maguire, and 


\section{WILD LIFE ON THE WING}

with a swoof he dashed across the garden into the wood.

"Oh Christians!" quoth Mrs. Maguire, and dropped her pot. Shacaim did not realize at first that he was saved, and how. He lay on the doorstep and gasped, and even when she put out a skinny finger and touched him, he was too exhausted to move. "Ah now," said Mrs. Maguire, "'tis a shacaim-thrush." For very long ago when she had been young, Mrs. Maguire had lived in the Co. Cork, and the old names lingered in her memory. A gaunt hen limped near and eyed him inquisitively, meditating a peck. "G'out," snapped Mrs. Maguire unex-

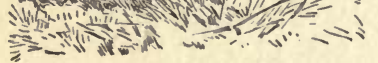
pectedly, and the hen departed surprised. "Musha, he's kilt!" murmured Mrs. Maguire sympathetically, and thrust a potato paring under his bill. Shacaim, recovering his wits, hirpled slowly back to the hedge.

"Musha now," said Mrs. Maguire, watching him ; "an him not to ask to fly!"

After that, morning by morning, she kept the I 60 


\section{THE REDWING}

last scraping of the pot for him. In fine weather he passed this by for hedgeside fare, but in rain he accepted it gratefully. For the spring was wet, although so sweet, and full of the jollity of the summer to be, that even the staid fowls felt the change.

Once a day the Yellow Hen wandered off by herself down the Glen. When she came back, her clamour drew all the rest of the fowls together, and they discussed the situation at length.

"Bad scran to thim burrds," said Mrs. Maguire, "the fox'll have the lot taken on me now if they're afther runnin' in the woods all day." And she sought more diligently for nests in the neighbouring undergrowth; but she found nothing, for where the Yellow Hen's eight eggs lay was only known to the Yellow Hen herself, and to Shacaim, the skulker in nooks and byways.

The chickens were brought out towards the end of the month, when the first whitethroat was tumbling discontentedly about the bushes, and the buttercups were a-flower. Mrs. Maguire received the Yellow Hen and her family with fervent benedictions, but she made the grave mistake of shutting mother and chickens up in the outhouse one evening. There was quite two inches space between the bottom 


\section{WILD LIFE ON THE WING}

of the door and the ground. Three rats went in on the first night, and only six chickens came out in the morning. Next evening the rats sent round the Fiery Cross and went again in force. She was a good mother-the Yellow Hen, but she had her limitations. In the morning she was found huddled up in the corner with a red beak, and her breast feathers littering the floor. It is true that a young rat with a bloody snout lay dead beside her, but the chickens were all gone. Mrs. Maguire lamented very much, and the Yellow Hen moped till next feeding-time, but it was too late then.

That was how the bank-rats learned that warm meat was good, and feathered meat particularly so. Mrs. Maguire might never again leave chickens outside her cottage at night. But the rats did not forget. Hitherto it had been only an odd one who crept past the house to the wood. Now they came nightly to the outhouse door, and as a matter of course made further explorations up the hedge. The throstle's nest in the ivy, though it was built so high that Mrs. Maguire herself must have tiptoed to peer in, was robbed one night. Shacaim, in his subterranean dormitory, heard the frightened bird flutter "chink-chinking" away, as the marauders clambered noisily up the 162 


\section{THE REDW ING}

trunk; and then the soft crack of an egg which slipped over the rim of the nest-cup and was smashed. $\mathrm{He}$ also heard the stampede as the waiting rats rushed to the feast, and Spideogue's malediction upon them as the commotion woke him. At dawn, yelk still dribbled from the ivy ropes about the door and the throstle grieved until the sun was high. The smaller people who live in the hedge bottoms all hate and fear the rat because his status with the Fur Folk is not well defined. His teeth are as the teeth of the squirrel and rabbit-expressly designed for gnawing or grazing, and yet he perverts them to the sucking of eggs and slaughter of nestlings. (The squirrel has also found out that flesh tastes good, but as yet he is not reckoned among the bloodhunters.) $\mathrm{He}$ slinks aside when cat or stoat is on the line, yet when they are gone, he hunts the frog and robin fledgling for himself. $\mathrm{He}$ is a pariah, hated by the small people and hunted by the great. Therefore he lives in colonies-there is safety in numbers-and the rat villages are not good places into which to stray for any but the bloodhunters.

That was the last day of April, and it rainedwarm driving rain which dripped from leaf and blade like balm, and buds and grass alike grew greener. New living things crawled among the 


\section{W ILD LIFE ON THE WING}

dead leaves, in nooks which in winter had been empty, and when Mrs. Maguire tramped in and out of her cottage, her cracked boots cut little pools in the mud. Mrs. Maguire grumbled at the spring rain, because her "skiatics" responded to it as surely as did the hedge buds after another fashion. Not so the birds. One and all they hymned it royally all day, until at evening the clouds blew eastwards, and over the purple shoulder of the hindermost, the moon rose upon a clear sky.

The sunset light began to fade from the woods long before it left the open fields and uplands. The blackbirds sang whole-heartedly in Coolnabrock, and the air was full of the sweetness of breaking hedge buds. The fowls strolled in to roost, conversationally, and Spideogue came down to inspect the leavings of their meal. Shacaim, skulking among the cabbages, tripped out, and they ate together hastily, lest the rats should come out and take them unawares. Presently a chaffinch in the hedge began to cry regretfully. She had built her nest dangerously close to the ground-even a cat clawing tiptoe might have reached it - and consequently one by one, her red-clouded eggs had been raked out. To-night the last had disappeared, and, gliding down a runway, she saw the tip of the thief's naked tail. Shacaim scurried back to 164 


\section{THE REDW ING}

the ivy-tree. He was only just in time, for an old rat came out the next minute, with the golden yelk still clinging to his whiskers. Shacaim preened himself and watched the robber distrustfully. Then Mrs. Maguire came out of her house, and looked across the woods to the sea. The sun slowly reddened the flanks of the last rain-cloud before he dipped; and the boom of the surf, as the tide turned, was borne up the Glen. "Shure the summer will come airly, this year," said Mrs. Maguire to herself. "The burrds is singin' all day."

She stood for a long time, looking through a gap between the tree-tops out across the Channel. (Shacaim down among the cabbages could not see it for the intervening woods and fields-the sea whither the clouds were driven, the sea whither the birds fly.) Then she slowly went back into her cabin with her fowls, and shut the door, for she always went to bed with the sun. Shacaim whetted his bill, and shook his feathers. It was roosting-time, but to-night he felt strangely reluctant to shut out the gracious 


\section{WILD LIFE ON THE WING}

spring twilight in sleep. The rain settled into the satisfied earth with gentle noises like a soft monologue, and there was a creditable veil of foliage over the hedge. In the elm-tree, Smól the Throstle, a throbbing silhouette, whistled and chirruped in broken mellow phrases, and his kind answered him from Coolnabrock. Shacaim crouched down on his perch and eyed the singer intently. More rats came out and ran about the bank, but he did not notice them. The throstle sang about the rain in short sweet notes that were themselves like the dripping of water-of the swelling of waterfalls, and of the circuit of the sap in the hazel-trees. Shacaim heard it all. Then Londub the Blackbird took up the motif, and in accents deeper and more mellow, repeated the old wordless pæan of the equinox, when the things of the elder years come together to bring forth life for the new. And with the blackbird's music, the life of the old things that was the redwing stirred, as it had already stirred in the leaves and the grass at the drip of the rain, and he knew that the breaking of buds and song, accompanying one another, and that after the songtime, comes the not less sweet silence of the woods when fledglings fill the nest. Shacaim heard it all. He drew himself up with puffed throat to honour I 66 
melody. Once, twice he chirped-the low go-to-roost of the redwing - but no other sound would come. His chords were rusty - he had forgotten how to sing. Londub went over his chant again, more certainly. He sang of warm sou'-westers, and of the flighting times when the birds fly north on the back of the spring hail storms. Shacaim heard that also. He straightened himself and tried again. Had he been able to stand where that blackbird stood, it might have been easier-even a skylark sings brokenly from the ground-nevertheless the second trial was more successful. His notes were low, but they were clear. Spideogue, prospecting among the cabbages, cocked his head on one side. This song was of unknown quality. The notes were soft, almost guttural, but the singer warbled on, enraptured, improvising chirps and turns, quite regardless that there were no ears to understand his music.

The sun went down, and the throstle descended for the night. It was long past Shacaim's roosting-time, but the evening was so beautiful that he stayed on and on, preening his orange flanks, and chirping to himself. $\mathrm{He}$ was so taken up with his new-born gift of melody, that he never saw a pair of keen eyes watching him from under a grass tuft. However, 


\section{WILD LIFE ON THE WING}

Spideogue, settling down to roost, saw them and swore. Shacaim caught the warning note, broke off in the midst of a gurgle, and ran to covert like a quail, and as silently. Nevertheless he was seen.

The rat did not spring - that was not a mode of attack which he affected. Instead, he sat up and polished his whiskers hungrily. This is a custom of the rat. He considers that a little by-play of this kind tends to reassure his quarry, Niny

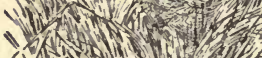

or any other game which may happen to be within sight. At any rate, supposing that he has made a false move, it is wise to cover up failure gracefully, by pretending that all along nothing was intended but an innocent toilet.

Shacaim ran into his dormitory, and squatted down in the dark. Then his heart misgave him -it would be safer above ground. . . . He suddenly felt the wild bird's inexpressible fear of enclosing walls, the tree-roots seemed to hem him in.... He would have turned back, but the dim oval of the entrance was blocked by some moving thing. The rat was sniffing outside. I 68 


\section{THE REDWING}

The rat was suspicious. A bird in a hole was outside his experience-it savoured of a trap. However, his curiosity was excited, and for all his wariness the rat is as curious as a squirrel. He sniffed down the shaft and as he expected the bird inside moved apprehensively. It was a very little sound, but the rat heard it. He licked his whiskers maliciously - then stole inside. ... 


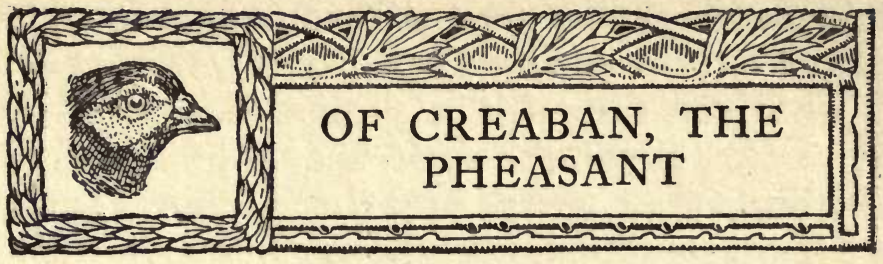

\section{I}

A LONG narrow strip of woodland came down to the back of the Tonsella farmyard. It was a windy cheerful place, not more than a hundred and fifty yards from side to side ; and in the evening the long slant rays of the sunset pierced right through the tree trunks from the stubble fields on the one hand to the Home-field on the other. The trees in the wood were chiefly beech and Scotch fir, and underneath them grew thick clumps of bramble, and the long millet-grass. Pigeons and tits visited the trees, and hedgehogs and fieldmice lived in the grass; but there was not enough covert to attract other of the wild breeds who lived in the big wood of Ballydare over the hills, and as a rule the Tonsella wood was a lonely place.

Nevertheless, one September day, it seemed a good hiding-place to one explorer, who entered it from its northern end which abutted on the outlying copses of Ballydare. Creaban the I 70 


\section{THE PHEASANT}

Pheasant was an alien to the countryside. He was coop-hatched, and earlier in the summer had been fostered on grain, with hundreds of his own kind, in the newly stocked coverts of Ballydare, where they were vigilantly protected from poachers and foxes; but as the autumn drew on, and his wing power increased, he strayed farther away from the shelter of the home-coverts, lured by the ripening corn and blackberries. The journey took him three days, travelling leisurely along the dense hedgerows which are the highways of the wild folk, and he arrived at Tonsella one sunny afternoon. The little wood was very still except for the chittering of the tits in the branches overhead, and for the humming of a thousand long-whiskered insect-things with flimsy wings, which hovered back and forwards over the blackberry clusters. In those mellow September days, Creaban had never yet heard the tap of a beater's stick, or known the whistle of shot around him; nevertheless within the past two days he had already found out that the free woods and hedgerows were not like the wellpreserved plantations of Ballydare, and he entered sedately with one timid eye on the covert.

At the top of the wood there was no path between the trees-it belonged altogether to the 


\section{WILD LIFE ON THE WING}

wild people. The rotting tree stumps, relics of an older generation of trees, were garnished with scarlet and yellow agarics, and the briar leaves were beginning to change to brown and orange. Creaban himself epitomized the colouring of the wood-dull green, glossy black, russet and gold. Three months later, when the copses were grey and dun, his bright feathers might prove his bane; but now he stepped into his rightful place in the scheme of things, and in the riot of autumn colours he became invisible. The wood-people were taking a siesta, and no one saw him as he paced carefully from one bramble thicket to another. Half-way down the wood the trees grew more sparsely, and between them cart-wheels had long ago ploughed deep black ruts, but Creaban went on; for so far he had had no need to fear man, nor indeed anything else. But presently he heard a quiet footstep behind some bushes in front of him. In the woods nothing is more to be dreaded than the rustle of an unseen tread. The experienced wood-people can generally recognize any given sound, whether it be the patter of a stoat or only the innocuous leaf-turning of a blackbird, and if they do not know the source of a suspicious noise, they retreat at once; but Creaban did not know this. So far his native wit had had 


\section{THE PHEASANT}

scant scope to show itself, and he had as little experience of wood lore as his barn-door fostermother-so he stalked inquisitively towards the sound.

All at once he came full upon a fowl who was standing expectantly, hidden up to her bill by the long dry wood grass. Creaban was no stranger to poultry. The first thing which he had known in life was the touch of a hen's feathers; and, as he had fed alone for so many days, he gladly welcomed this Pullet's companionship. She was an ochre-coloured bird, with a small comb and a draggled tail. Her spine was curved like that of a partridge, and she ran through the bushes as nimbly as Gurra-gunt the Corncrake, or as Creaban himself. As Creaban followed her, she was shy, and tripped away from him ; but presently, when he stopped to scrape for pignuts in a clearing, she ventured to creep up to pick at the insect-trifles which he unearthed. At first they were both somewhat uncertain of one another perhaps Creaban had forgotten the barn-yard dialect of his foster-mother, and failed to make her understand him; but they were kinsfolk, 


\section{WILD LIFE ON THE WING}

albeit in distant degree, and, before the sunshine had left the valley below, they were feeding side by side in the friendliest fashion. But all the while the Yellow Pullet led the way farther and farther down the wood, and Creaban followed docilely enough. At length they came to a place where the trees grew very thinly, and the undergrowth was honeycombed with runways. The grass was trampled down, and a blue wreath of smoke clung among the branches overhead. It was the end of the wood. To the left a thin hedge separated the trees from a field; and the Yellow Pullet crept through it on to the open grass without hesitation, but here Creaban drew back. There were more fowls feeding in the field, perhaps a score of them-brown, white and yellow; and as Creaban stood uncertainly under the fence, a great red cock stood up and told the world that it belonged to him. The Yellow Pullet ran across the grass and joined them; but Creaban, hand-reared as he was, already mistrusted wide open spaces and strange surroundings, and he slipped back into the wood. But a few minutes later, when he heard the red cock crow again, he stood on tiptoe and replied with the loud clear challenge of his kind: "Kor-kock!" that it might be known that for the first time a pheasant had come to Tonsella. 
Creaban roosted on the limb of an oak-tree, and when the dawn-wind stirred the woods and set them swaying and sighing, his perch jarred and creaked against its neighbour and woke him. It was still dark, although a glamour in the eastern sky told of the sunrise to be ; and Creaban, believing himself to be the first bird astir, would have tucked his bill away among his feathers again had not a distant call suddenly startled him broad awake.

Then, for the first time, he heard that War of Wartburg which is waged from every hen roost up and down the countryside at dawn. The cock from Dromore, on the other side of the valley, began the chorus, as was his custom, before one could tell a black hen from a grey, and it was taken up by every rooster for two miles round. Every morning they uttered the same old declamation, and gave the same answers to their neighbours. The Tonsella cock had never seen his rival at Dromore, but he knew him as well as if they both inhabited the same yard. Both were madly jealous of one another; for each was led to believe that his rival was a bird of great prowess and good fortune, who inhabited the finest manure-heap in Ireland, and had an untold following of 


\section{WILD LIFE ON THE WING}

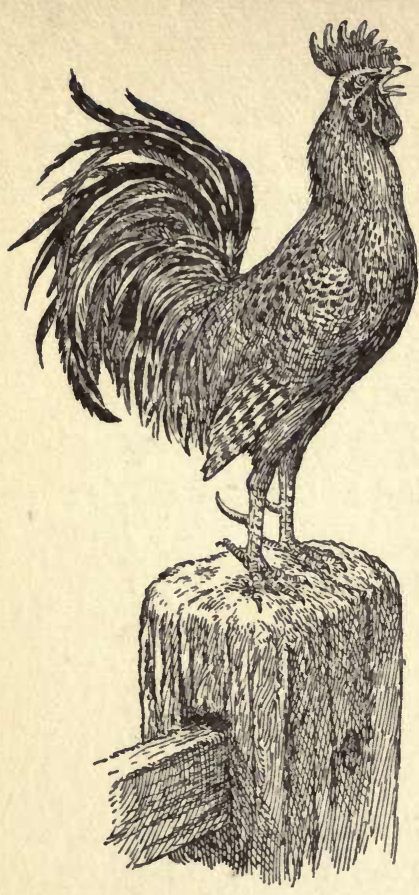

admiring hens. Morning by morning, from dawn to sunup, each trumpeted aloud his unalterable resolve to uphold the honour of his own yard against all comers.

Creaban paid little attention to the far-off challenge from Dromore, but the nearer jubilation from the bottom of the wood stung him to emulation. With a sudden thrum and clapper of wings, which made the woods ring, he gave the terse defiance of an arrogant cock-pheasant, There was a sudden silence in the yard, and when the Tonsella cock crowed again, the challenge was intended, not for his Dromore rival, but for one nearer home. It was not only a challenge but a summons. As the daylight broadened the small birds woke, and the pigeons flapped lazily out to breakfast in the barley fields, but Creaban did not think of food, as he kept steadily on his way towards the farm. He had never been angry before. Hitherto he had sometimes been afraid of strange birds and beasts, but he had never wanted to fight them. 176 
This morning however, for the first time in his life, he was very angry. He did not choose that any other bird should share the overlordship of this wood with him, and he meant to fight for it if need be. Twice he stopped and crowed, and each time the cock flung the answer back haughtily from the yard. Finally he took wing, and skimming down the woodside, wheeled in among the trees at the back of the farm. There he caught a glimpse of yellow feathers lurking under a bramble brake, and, with a recollection of his companion of the day before, he alighted with a flourish and crowed again. He had scarcely folded his wings to his liking before a big red cock appeared in the gateway which led from the farm-yard to the wood.

The "Chickery-Cock" of Tonsella was a notable bird. There were fifteen hens in the yard, not counting the last-hatched chickens, and they all belonged to him. So did the yard itself, and also the Connell family, who lived in the low thatched house which opened on to the yard, and into which he led his hens on foraging excursions every day. The "Chickery-Cock" was the only bird in the yard who had a name to himself. The others were: "the Yeller-Pullet o' Widdy Brady's" or " thim white hins o' Comerford's clutch," 


\section{WILD LIFE ON THE WING}

or whatever it might be, according to where Mrs. Connell had obtained the antecedent egg; but the "Chickery-Cock" had been hatched from a home-laid setting, and he was the pride of Mrs. Connell's heart. He derived his name from his fine bronze hackles and wings, speckled, or as Mrs. Connell expressed it" chickered" with black-a legacy from some far-off gamecock ancestor perhaps, from whom he had also inherited his consummate pride in himself, and a latent craving for battle. He ruled over his admiring train of hens with tyrannical rigour, and allowed nothing from a rat to a man to approach his hen-house unchallenged. Hence, when he heard that insolent note in the wood behind his yard, he shook his fine "chickered" hackles and strode out to punish the trespasser.

Creaban forgot all about the Yellow Pullet in the brambles, and ran to meet the newcomer half-way. Although he had lived with scores of his own kind in the woods all the summer, he had never wished to fight with any of them, but now, as the Cock drew in his head and crumpled his right claw against his breast, Creaban suddenly felt an overwhelming hatred of him. He began to trip across the clearing with little niggling steps. The hens scattered to right and left as he came, but he took no 178 


\section{THE PHEASANT}

notice of anything but the Cock's angry red face. They stood bill to bill for a minute, making little feinting springs into the air. Then they closed, and the watching hens could see nothing but a whirl of ruffled feathers as they skirmished round the tree trunks. The "Chickery-Cock" had spurs twice as long as those of the Pheasant, and moreover he had proved them many times on raiding cats, and egg-stealing rats in his hen-house ; but although Creaban was inexperienced he was the nimblest bird on his feet, and did not often allow his antagonist to come to close quarters. The Cock drew deep hissing breaths, but Creaban thrust and feinted silently. The Cock's full wattles hung on either side of his bill-Creaban suddenly sprang in and caught hold of the lobe on the left side. The Cock fluttered this way and that, and jumped two feet into the air to shake off his enemy, but Creaban clung on, and struck with his spurs whenever he saw an opening. Bruised and bewildered, the Cock made for the yard, dragging the Pheasant with him. As he crept under the gate he managed to shake himself free, but by now Creaban was so full of the joy of battle that he had no room for any other thought, and without looking where he was going, he ran eagerly after his enemy. The farmhouse door was shut fast, for 


\section{WILD LIFE ON THE WING}

it was too early for men to be astir. A big black sheep-dog sprang to the end of his chain and barked vociferously, and a pair of goats wheeled round to stare at the intruder. But Creaban cared for none of these things. He saw the "Chickery-Cock's" waving tail plumes disappear through the little open hatch in the fowl-house door, and he gave chase forthwith. Inside, it was dusty and very dark. Before Creaban could take his bearings in the unaccustomed gloom, the Cock rushed out from an ambush in the corner and knocked the breath out of his body. The awestruck hens loitering outside the door, heard the confused sounds of the battle that raged within; and although none of them dared to enter they added their voices to the hubbub. It says much for the just consciences of the family asleep in the house next door that they did not awaken sooner; but presently there was a short armistice in the hen-house, and during the interval a window was thrown up, and a voice screamed outside : " $O$ whirrah, whirrah me little hins ! Shure the fox is got in to thim, and they roarin' like the divil and his childher. Go down now, ye lazy omadhawn-_" Creaban heard the dreaded voice of man, and ran wildly round the place looking for a way of escape. For the moment he forgot about I 80 
the Cock, who crouched in a corner, too breathless to resent it even when the Pheasant stumbled over him. Suddenly the door was flung open, and a flood of sunshine poured into the place. Creaban, wholly dazzled, dashed towards the light, and swinging sideways like a woodcock, brushed between the men in the doorway. A hand clutched at him, but he tore himself free. Leaving a handful of feathers behind him, he hurtled over the barn, back to the safety of the woods.

\section{III}

The Yellow Pullet's real title was: "That Yeller-y Pullet o' Widdy Brady's" ; and Mrs. Connell was wont to qualify this by declaring that the Yellow Pullet had "the head of a hatchet." By this she meant that this particular fowl contravened all the known conventions of poultry. Night after night the Pullet roosted thirty feet from the ground, on a limb of the great ash-tree which hung over the yard. In the daytime, while the rest of the fowls wandered obediently from straw-heap to stubble, and from stubble to hedgerow, as their lord and leader the Cock thought fit, the Yellow Pullet, if left to herself, would always turn to the wood. Whenever the Cock saw 


\section{WILD LIFE ON THE WING}

her moving away from the rest of his harem, he would run after her and hustle her back again ; therefore she used to wait her opportunity to slip off when he was not looking.

Some detail of Nature's machinery had surely been out of gear when she produced the Yellow Pullet. Something had lacked, and, to supplement it, she drew upon ancient plasm from some almost forgotten hoard. Therefore, with her partridge build and power of wing, some far-off ancestor, who lived in the jungle in the days before a Dorking was differentiated from a Brahmapootra, had bequeathed to the Yellow Pullet his love of deep covert, of lofty perches and of woodland fare, and his hatred of bare open country and the walled-roofed houses which men build. When the rest of the fowls squabbled round Mrs. Connell's petticoats for their morning meal, the Yellow Pullet lurked furtively at a distance, and only crept to the feast when all the rest had finished, and the yard was empty. Mrs. Connell had vainly tried to shut her up at night. Coercion only drove her cackling through the gate to the wood, where she could defy pursuit. Now that she was in the sixth month of her age and follies Mrs. Connell, despairing of her, had taken to reckoning her apart from the rest of the "Chickery-Cock's" seraglio: "Shure I 182 


\section{THE PHEASANT}

have fifteen fowl, not counting that there Yellery Pullet I had o' Brady's, the crather."

The duel in the hen-house scared the Yellow Pullet so much that, without waiting to feed with the other hens, she slunk away into the wood, and passed the early part of the forenoon among the bramble brakes. It was Sunday, and but for the placid cawing of rooks, and the tinkle of the Chapel bell at the head of the valley, a Sabbath stillness lay over the countryside. The wood was as quiet as a church; even the autumn wind seemed to pass without stirring the trees. An ordinary hen would have been lonely by herself, and have returned to feed with her companions, but the Yellow Pullet was contented enough, and strayed farther and farther into the wood. Nevertheless, when she came upon Creaban, who was scratching up his noonchine under the hedge, she welcomed his companionship. Creaban was nervous after his adventure of the morning and listened anxiously to every strange noise ; but the Yellow Pullet as usual was quite unmoved, or only curious, about sounds which would have driven the real wild people to covert in dismay. She was wholly taken up with Creaban, and as her carelessness gradually overcame his own fears, he paid greater court to her. Together they took a sun-bath at the foot 


\section{WILD LIFE ON THE WING}

of a fir-tree : together they raked over all the secret feeding-grounds which had hitherto belonged to the Pheasant alone. In the peace of the woods, and the new companionship, the spirit of the old jungle-fowl which slept in the Pullet awoke. She followed Creaban down shady runways, and into depths of covert where she would never have dared to venture alone. The sun filtered through the leaves, and turned Creaban's feathers to gold. He was altogether splendid-gorgeous to look upon-and he belonged to the woods. The Yellow Pullet forgot about the yard, about the Cock, about men. For three sweet hours of that September day she was as verily a thing of the woods as Creaban himself.

Nevertheless it was the Pheasant with his superior woodland training who first heard a stick threshing the bushes at the bottom of the wood. Now although Creaban had never yet heard the tap of a beater's cudgel he was nervous after his adventures of the morning; and as the ominous noise of twigs smashing grew nearer, he ran a few steps up the wood, and then hesitated. It was against his principles to take wing as long as he could lie safely in deep covert. The noise came nearer-trampling, crackling, shouts of " Hi cock !" Creaban lost his head and began to run hither and thither uncertainly. I 84 
But perhaps, as it turned out, this was the best thing he could have done, for panic is infectious, and the Pullet caught the alarm. Men, bent on mischief, were in the wood, and she had only one idea-to run from this unknown place back to the familiar bondage at Tonsella. She thrust her head out before her like a landrail, and ran down the wood. And Creaban followed-followed although it was right into the line of the oncoming men, for there was a decision about his companion which bade him trust to her guiding. He stubbed himself against briars; thorns scraped his feathers; he heard the mighty noise of men trampling all round him. Willingly now he would have taken wing, but they were running through a thicket of beech saplings, whose interlacing branches held him as if in a cage. He could see nothing but the draggled yellow tail of the Pullet in front of him. But when they were half-way through the brake, he realized that the crashing of the men to right and left of him was behind, instead of in front. Was the gauntlet nearly run ? Was the way of escape open before them ? Suddenly the covert abruptly gave place to grass. Were those twin stems set in front of them really trees?-It was the Pullet who saw them move, and guessed their nature. She swerved aside noisily. 


\section{WILD LIFE ON THE WING}

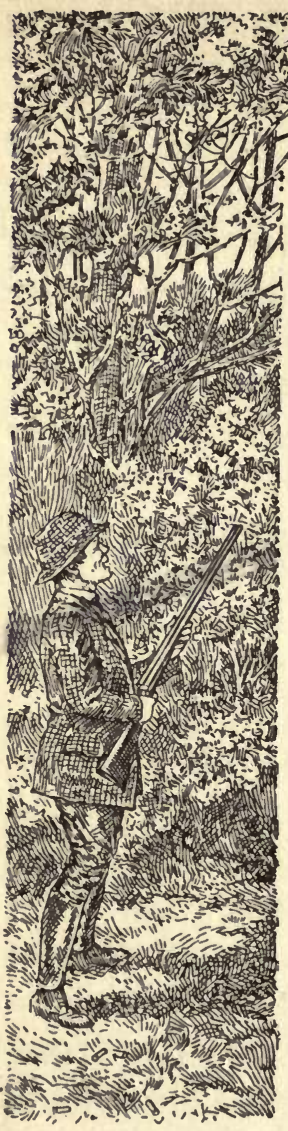

"Begor, I have him, here," yelled the man, and struck the bush.

The Yellow Pullet fluttered up on windy whirring vans, whose power long generations of disuse had staled. She saw the man's hot red face below her. She struggled up-up, higher than the sapling tops. She had never flown so high. She saw the line of beatersfive abreast-stretched across the wood: she saw the man who stood under the hedge raise his gun and glance along the barrel. The Yellow Pullet shrieked hysterically, and beat impotently against the golden leaves above her. The old spirit of the jungle-cock in her burnt as strong as ever, but time had left him meagre instruments-wings round-quilled and loose, a heart and lungs unused to violent flights. She I 86 


\section{THE PHEASANT}

slipped downwards with a scream. But instead of the crack of the gun, loud laughter rose. The levelled gun was lowered. "Is it yer mother's hins ye're afther showin' us, Pat ?" jeered the men.

To the sound of mocking laughter the Pullet crashed back to earth ignominiously. But even as she reached it, through her shame and bemusement, she heard another sound-the clean boom and whirr of a rising cock-pheasant. "Mind out now" ... "Aim wesht, Pat" "Hooroosh_— !" The Yellow Pullet felt Creaban's whirring shadow eclipse the sun above her-then she heard the futile report of the gun, fired flurriedly as the guffaw was choked on the marksman's lips. But the swoop and whistle of Creaban's wings had died safely away before the echo of the shot ceased to ring through the wood.

IV

That night they clipped the Yellow Pullet's wings. She did not scream but only blinked stupidly at the sunset while her quills fluttered on to the straw. Afterwards when she ran across the yard, the other hens, who hated her, realized that something was amiss, and after the fiendish fashion of their kind were all agog 
WILD LIFE ON THE WING

to drub her now that she was crippled. She was rescued before extremest lengths were reached, and then ran shrieking to the wood. She knew that she was changed, but the wood would be the same. But it was not. Her cackling drove peace from the place: the pigeons clattered out of the trees: the fieldmice hushed their squabbles as she passed; and though she wandered up and down until Charles' Wain hung over the mountains to the north, she did not find what she sought. It was still sweet evening, and under the spell of dewfall even the Tonsella farmyard-ordinarily full of the reek of ill-kept beasts and men, of shag tobacco and of cooking food-smelt clean. The Yellow Pullet's roosting perch in the big ashtree was three stages up-one flight to the gatepost, a higher to the barn gable, the third, a mere hop to the branch. Seven times she fluttered at the gate-post, seven times she breasted the second bar of the gate and fell back gasping. Her clamour brought the dog, the cat, the other fowls, to stare and comment derisively. Last of all she was carried off head downwards, still shrieking, and shut into a coop. For the first time since she roosted outside her mother's feathers, the Yellow Pullet slept on the flat ground in the darkness, instead of aloft in the starshine with the wind under her breast. I 88 


\section{THE PHEASANT}

Next day it was the same -and the next. Now that her wings were clipped she had no sure escape from the loathed advances of the "Chickery-Cock," from the sly spitefulness of the hens. Nevertheless, as the spirit of her old-time forbears had not been shorn away with her quills, she still ran to the wood. For half a day she had tasted of the cup of freedom, and, like all who drink that intoxicating draught, she believed that henceforward it would be a panacea for all her ills. Hence, although scraping in the dunghill would have won her more succulent food, she shunned it, as she shunned the porridge which men threw to her, and fed on scantier woodland fare, clucking lackadaisically, And as where she went, the "Chickery-Cock" with his seraglio must follow, it became quite a common thing for the Tonsella fowls to wander farther afield than ever before. But the days went by, and the Yellow Pullet never saw Creaban.

Until that Sunday when the shot snipped away the twigs behind the tail, Creaban had considered men a nuisance, though nothing 


\section{WILD LIFE ON THE WING}

more, but now he was afraid of them. Previously he had fed openly in the fields in the forenoon; now, as soon as the dew was off the gossamers, he went back to the woods. When he crossed the stubbles he did not run with his head up as heretofore, but crouched low like a corncrake; and he learned to hide so skilfully, that a man might walk within thirty yards of him without seeing his glossy green neck above the clover. The slightest tap of a stick was enough to make him run down the hedge like a fox. An Irish hare and an Irish pheasant are the Ishmaelites of the countryside. Every man's hand is against them, and now that the day of the "red-licence" is past, that hand is more frequently and effectually armed. Every Sunday and holiday the Connells and their peers beat the wood and hedges, and by the beginning of October, Creaban was as shy as a hawk. About this time, the woman in the cabins in the valley began to notice that their fowls rambled farther afield than usual. At first they set this down to the abundant food which the birds found in the newly reaped cornfields, but, as time went on, they found that not all the band came back. Mrs. Kegan's white cock came home one night with his head bleeding and his eye knocked in ; Mrs. O'Grady's brown rooster had his 190 
wattles badly torn ; and Miss Houlahan's bird never came back at all. There was a feud in the hamlet. Miss Houlahan accused Mrs. O'Grady's cock of the murder, and Mrs. O'Grady accused Mrs. Kegan; but even after the rival birds were shut up, the trouble continued. Hens wandered far from home, and the fox took them. The Poultry claims of the Carkenny Hunt had never been so large. But what made the chickens stray? It was mid-October before the mystery was solved.

One forenoon, Bridget Sullivan of Dromore heard a commotion in the rick-yard, and found the Dromore cock-a big pied bird with the legs of an emu-lying wheezing on his side with the breath knocked out of his body. His assailant had evidently made off at her approach ; but the ground was starred all over with three-rayed prints, and a long bronze feather lay draggled on the mud. That feather was the key to the perpetrator of this and the other outrages, and Creaban was hunted more than ever.

It was this persecution which drove him back to Tonsella. The Yellow Pullet, scratching in the straw heap under the eye of the tyrant Cock one dull October day, heard his voice up in the wood, and the Cock heard it also. She could not know that it was the 
WILD LIFE ON THE WING

desire for war, not love-that it was the brazen voice of the "Chickery-Cock" rather than her charms-which had lured him back again. Since the day when Creaban had fought the Cock in his own yard, the Tonsella fowls were shut up all night, and now as they awoke tardily in the dark hen-house every morning, they heard the clear defiant : "Korkock!" Then the "Chickery-Cock" would draw himself up and crow loudly in answer, furious that a stranger should trespass so closely to his yard, and he not be able to resent it ; and the Yellow Pullet used to cower close to the door, and watch eagerly for it to open. But although at times the Pheasant was insolently bold, he was wary enough where men were concerned; and later on, when smoke was blown from the house-chimney, he never went near the place. Then the "Chickery-Cock" and the Yellow Pullet for divers reasons went to look for him. They found where he had scraped for pignuts; they found his secret dusting places. Three days they sought, and on the third day the "ChickeryCock" found him. The Yellow Pullet ran from the brake where she loitered, but she came too late. The "Chickery-Cock" stood alone in the clearing, and at his feet lay a tuft of shining feathers, crimson-quilled. Trium192 


\section{THE PHEASANT}

phantly he drove his harem back to the farm.

For a week they skirmished thus, now one and now the other claiming advantage, yet neither admitting defeat; yet all the while Creaban was so alert that no men saw him, although they knew that he was there. The Yellow Pullet was content, for all this time she lived in the wood. Only, at sunset her courage failed. She dared not stay out all night, and followed reluctantly after the rest of the seraglio. She it was who fomented the feud, for she patiently tracked the Pheasant from covert to covert, and, as where she went the Cock pursued, the combatants constantly encountered one another. But so far they never fought to the finish, for when the "Chickery-Cock" found that he was getting the worst of it, he retreated within sight of the yard, where Creaban dared not follow; and the Pheasant could at need escape into the denser bramble brakes whose geography he knew so well, and where the Cock could not give his mighty spurs fair play. But each armistice only made the rivals hate one another more. 


\section{V}

On the eighth day of the feud, the " ChickeryCock" remembered a certain rotten tree stump which stood in a clearing of the wood. This stump was the especial discovery and private property of the "Chickery-Cock." No other stump afforded such noble centipedes, such succulent slugs: immense light-shunning things lurked under its mossy bank, and among the damp flakes of touchwood which he chiselled from its bulky sides. It was a mild afternoon, with a sky dappled grey and purpled after the fashion of Irish skies in autumn, and soft south wind. Except for the buzzing of a few late wasps, it was very still in the wood. The "ChickeryCock" went straight to his tree stump. The hens strolled after him, clucking conversationally. Even before he came to the clearing he heard a rustle of busy movement in the place, and his wattles grew redder with a premonition of what he was to see behind the bushes.

Upon the stump-his sacred stump-stood Creaban, chiselling at the rotten wood, and near-by the Yellow Pullet waited expectantly. The "Chickery-Cock" clucked angrily, then spun in a semicircle with drooping wing to I 94 


\section{THE PHEASANT}

woo his renegade slave back to the harem. The Pheasant drew himself up. In the dull clearing his gay feathers held the eye like a gleam of sunshine. He came down deliberately from the stump. The Cock began to breathe short and noisily. He clenched his claw against his breast, and shook his hackles until they stood round his neck like a lion's mane. His pride in himself was monstrous :

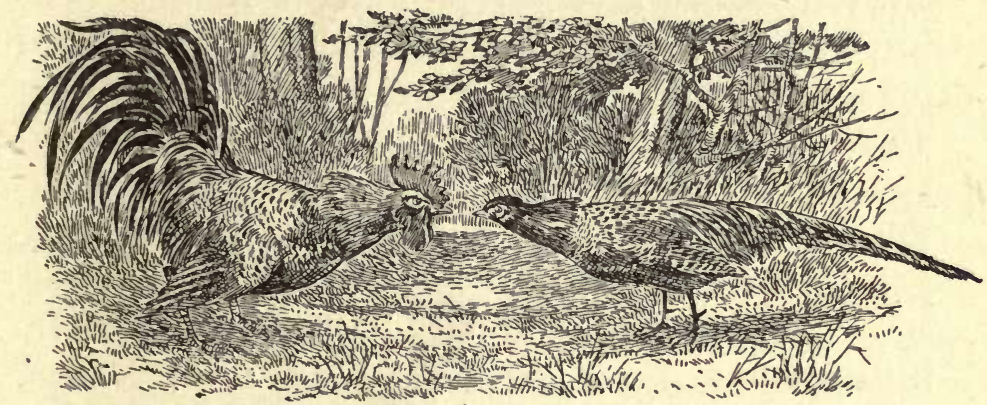

at that moment he would have fought anything from an eagle to a kitty-wren. They riposted bill to bill for a minute, then, casting aside the courtesies of tournament, they closed. Twice up and down the clearing they skirmished, and the hens fluttered out of the way as they came. The Pheasant gave up first, for his crop was heavy and he gasped for his second wind. He dodged to covert, and the "Chic- 


\section{WILD LIFE ON THE WING}

kery-Cock," albeit huskily, crowed that the first round scored to himself.

He had better have kept his breath. Creaban was upon him again almost before he stood on guard and, taking him by surprise, bored him up against a bramble-bush where he could not give his spurs fair play. But the "ChickeryCock" was both cunning and nimble for so heavy a bird. He slipped aside, and though Creaban drove savagely at him as he turned, he was so thickly feathered that the blow glanced harmlessly off his spangled scapulars. That was the end of round two, and the advantage so far lay with the Pheasant; but he lost anything which he might have gained in the next, for he rushed in rashly, and was met by a kick which knocked his breath away.

So the duel went on with alternate bouts of fierce encounter and gasping armistice. In his duels with the cocks in the valley, Creaban had perfected one efficient method of attack. Could he but once fasten his bill on to those pendulous wattles he would have his antagonist at his mercy. But the "Chickery-Cock" remembered the drubbing which he had received in the yard last month. He constantly broke away out of reach, never allowing his antagonist to make good his hold, and by running in 196 


\section{THE PHEASANT}

a semicircle made a counter-attack on the Pheasant's flank.

If the "Chickery-Cock" had been a pen-fed bird he would have stood no chance against Creaban's forest training; but as it was he was accustomed to forage far afield, so that his muscles were toughened with exercise, and as far as nimbleness went he was a match for the Pheasant. Moreover he was much the heavier bird, and compared to those of Creaban, his great spurs were as cutlasses to "knuckledusters." Again and again he drove his rival from the field, but before he could call up his wives to celebrate the victory, the Pheasant was back again, his tail quills bent, his breast feathers kicked awry, but eager as ever for another bout. The "Chickery-Cock" had righteous motive too. The wood was his: he had foraged in it for two summers and none had disputed his right. Neither hawk nor cat dared threaten his seraglio when he was by: the smell of man was upon him, and he carried something of the fear and puissance of man into the wood. But this audacious interloper showed no fear of him : he struck and ripped and pommelled him - his spur was red-and yet he could not drive him from his domain. Indeed it taxed all his strength and skill to keep him at bay.

Nevertheless at the twelfth round Creaban was 


\section{WILD LIFE ON THE WING}

much the more severely punished of the two: his wings drooped, his bill gaped for air. $\mathrm{He}$ could not come to close quarters, and his spurs were no match for those of the Cock. He had his wings, but flight is only a last resort in such a duel as this. Flight means a certain precariousness of balance at the moment of alighting, and Creaban dared not take any risks. He knew that a false step or an instant's delay in fence, and the Cock might snatch a hold of his neck feathers, and where the Cock held there he struck. One of those lightning blows would smash his skull or rip up the big vessels of his throat. The trees around him, the watching hens, all swam together in a red mist. He saw nothing but his enemy's face, barbed by a stabbing bill, and although his heart thudded as though it would beat its way out of his ears, still he urged his tired muscles to greater effort to escape the Cock's terrible spurs. Already one slashing kick had gone home and stripped a crimson feathered tag of skin from his thigh, laying the silver tendons bare. He seemed to be nothing but a springing kicking automaton: he had long ago forgotten why he fought. He only knew by a strong inexorable instinct that come what might he must not run away. If he quitted the field now his right to the wood would be gone. 198 


\section{THE PHEASANT}

Never again in the dewy mornings, before the glamour in the east was trodden out before the rising of the sun himself, would he be able to claim the fields of Tonsella as his own. He would be driven to lurk in secret covert while the Cock, man's bird, encroached on the free wood. ... There was guile in the fashion in which with drooping wing he crept across the clearing before the Cock's onslaught. The " Chickery-Cock," full of the lust of fight, fell into the trap. He was more than half exhausted himself, but he charged mightily. Creaban heard his short noisy breathing, and the scurry of his feet behind, and swerved aside. The Cock overshot his mark and crashed into the bramble brake. Before he could recover himself Creaban saw his chance. He seized the great hanging wattle and clung to it. He was too exhausted to pull or tear at the tough red flesh. $\mathrm{He}$ merely hung on like a dead weight, while the Cock, all his bravado gone, ran cackling hither and thither. He had been superbly sure of his own defences, but this firm coercive grip at his throat threw them out of gear. This attack contravened all the known laws of battle : he could not meet it. He tired himself by his own strength, and with his weakness came the Pheasant's chance. The Cock was beaten with his breast to the moss: Creaban dropped the 


\section{WILD LIFE ON THE WING}

bleeding wattle, and springing up, struck. His spur smote the Cock squarely-a clean cut below the ear. The Cock gurgled: then his blood-choked bill sank forward, and his wings shivered and drooped flaccidly in the death sickness. The battle was over.

Creaban stood on the stump, and whirring his stiff wings, crowed hoarsely. Wild had met tame, and for once in the history of the wood, the wild had won. The "Chickery-Cock" lay still and a purple stain widened and spread on the moss under his bill. One by one the hens went to peer at him with vacuous curiosity. Only the Yellow Pullet did not go with the rest to gaze at their fallen lord, but watched how Creaban, drooping with weariness, slowly left the clearing.

But now a golden streak behind the trees told of sunset, and in the shadow of the bushes the light was already beginning to fail. A bat flitted overhead, and at the sight the hens grew uneasy. Ages ago the very existence of their race had depended upon the promptness with which they went to roost before snakes and cats and other night-prowlers were abroad, and the impulse still dwelt with them. But as a rule the "Chickery-Cock" himself led them back to Tonsella. To-night they were widowed. They talked over the dilemma noisily and strolled 200 
about the clearing, watching furtively, but still the Cock did not move. Then a second bat came out, and they dared delay no longer. In twos and threes the whole seraglio slunk homewards.

All, that is, but the Yellow Pullet. The reign of the tyrant was over. Why then go back to his bondage when he could no longer coerce her? She was of the woods now, and the woods belonged to the conqueror. But first she must leave the clearing, for the smell of blood and of death was over the place. No innocent folk would hunt that way tonight. The gossiping of the hens still came faintly up the path to Tonsella. She turned and $\mathrm{ran}$ in the other direction.

It was dusk under the trees. Big white moths fluttered overhead and the robins went to roost. The Yellow Pullet had never been so far from home before. The wood seemed full of the rustling of furry-footed things. If she had not had the taint of man about her she would not have gone even so far in safety. By this time her sisters were all securely shut into the yard at Tonsella, nevertheless she felt no fear. As she went, she heard the patter of feet in front of her, and the twigs still swung as if something had but just passed that way. The first stars swam in a rift in the clouds 


\section{WILD LIFE ON THE WING}

overhead, as she came to the edge of a larger clearing between the trees, and one by one the wood birds went to sleep. There she found Creaban drinking the bitter mould-flavoured water which had collected in the crevice of a beech-tree's knotted roots. His gold and sable feathers were invisible in the dark : he was of the woods, and the woods hide their children well. But the Yellow Pullet came from Man, and in her case the powers which had painted the Pheasant had long since gone astray. Lemon and white, she was visible from one side of the clearing to the other. And Creaban had had enough of man-bred birds that day; he was bruised and sore from the bill and spurs of such a one. $\mathrm{He}$ clattered to a perch twenty feet aloft.

The Yellow Pullet was left alone. It was too dark to go farther; it was too late to turn back. Three times she fluttered at the tree trunk and fell back impotently. The trees stood bare-boled seven feet from the ground, and her clipped wings would not bear her to the safety of so high a perch. She did not know that the still wood contained more secret dangers than the noisy yard at Tonsella. There, under the ægis of man, even after her wings had been crippled by his shears, she might roost safely on the ground if she pleased. 202 


\section{THE PHEASANT}

But for the first time the wood seemed dark and rather awful. Clucking uneasily, she sought a low laurel bush, the only flight which she could compass. It grew at an oblique angle, but clinging to it sideways the Yellow Pullet tucked her bill into her backplumage contentedly, and forthwith forgot the darkness and the loneliness of the place. The night wind sang her lullaby as the young starshine shone upon the wood.

$$
\text { * * * * }
$$

She woke as she had awakened many mornings in the yard at Tonsella with the voice of the Pheasant in her ears: the world

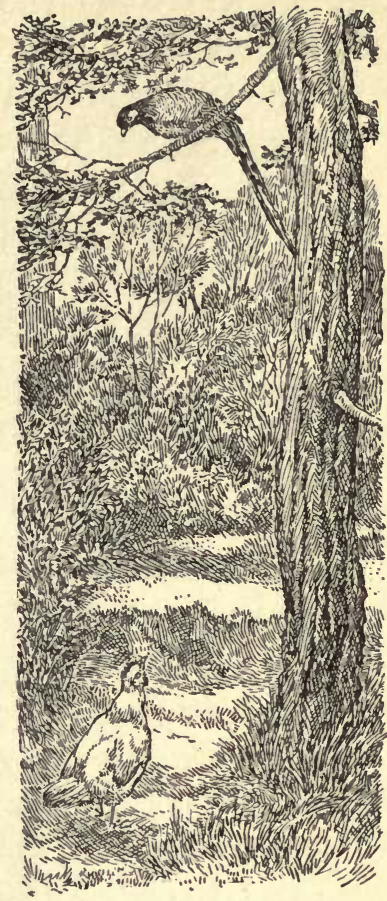
was grey with the conflicting light of the moonlight and the "false dawn," and the smell of dew was on the leaves.

"Kock-up! Rock-up! Kock-kock!"

The Yellow Pullet jerked her head from her feathers, broad awake. This was the birthday 


\section{WILD LIFE ON THE WING}

of her life : the first day that she would spend in the wood's freedom. The spell of the dawn was over the place-strange noises and strange smells, and over all the loud dominant voice of Creaban. She thought that he was calling as he had called so often outside the yard at Tonsella, and she dropped off her perch with a contented cluck. He was in the next clearing.

"Kock-up-Rock up!"

O simpleton, could not the spirit of the old jungle cock who had led you so far have warned you now? She came to the glade's edge, so boldly that a certain skilful hunterthe same who had aroused the Pheasant's execration-was staggered, suspecting a trap. Then, because he was a wily hunter, he crouched, pads down, and crept nearer. The bramble leaves rustled, and the fading moonlight flickered on them-still she did not see. "Go - back - Go - back - back - back !" warned Creaban from his tree; but she thought that he said: "Come-come," and his voice was the voice of the woods. She saw, but did not heed, the stare of the hunter's eyes - that sinister unwinking stare which sets the hearts of the wood-people thudding. She was both of the wood and of the yard-the 204 


\section{THE PHEASANT}

Yellow Pullet-and yet she had learnt the lore of neither perfectly. Therefore she clucked, and ran across the glade straight to where the fox crouched waiting. ...

A flutter-a strangled scream-the pattering gallop of pads through the thicket, and the clearing was empty but for a feather with a crimson shaft. The Yellow Pullet had her wish. She went to the deep of the woods. 


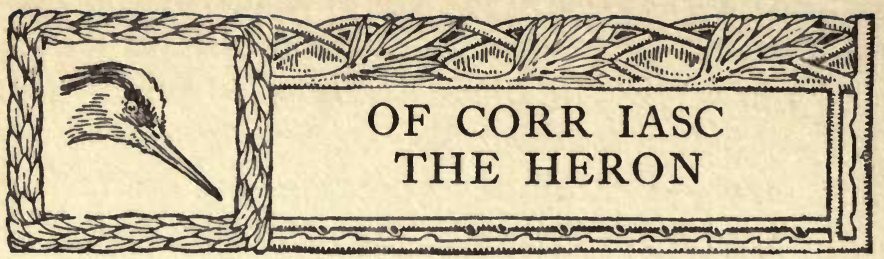

I

Men came to Ballongarry in the autumn and hall-marked the woods from Ruthcorrig to Dwerning with axe and saw. By January the hillside was littered with stripped trunks, which looked like corpses on a stricken field; and the cart wheels ploughed rutty tracks into the heart of thickets which had belonged to the wild people since the year of Vinegar Hill. Three people watched this clearing of the hillside. The first was Cornelius Geoghegan, of that well-known firm of linen manufacturers, Geoghegan, Macfarlane \& Co. "Worthless timber!" said Cornelius Geoghegan, "cut it down."

The second was Andy Hogan, in his cottage in Dwerning Glen. He leaned against his door, smoking his pipe of an evening, and said: "The dirthy blackguard above has half the wood cut down." And he kicked the door-post savagely. 206 


\section{THE HERON}

The third parties who were concerned in the devastation were the herons.

A little stream trickles down the hill to the head of Dwerning Glen. There it fills the great basin of the Quarry Pool, whose steep wet walls-since men left off blasting stone out of them-are shaggy with ferns and briars. Great trees lean over the pool, and at the upper end it is guarded by a wire fence, for the avenue to Ballongarry House runs by the Quarry here. The other side of the pool is low and shelving; and here the overflow runs down the glen in a stream which in winter is full to the brim, but which in summer is hidden under a tangle of meadowsweet and vetches. When the woods were younger there had been many herons' nests on the trees above the pool-even twenty years before the "clappering" of fledglings had made the glen merry; but now some of the trees were shattered, and as many more were empty, and where, in the days of old Geoghegans, one might have seen half a dozen herons, now would be only one.

Andy Hogan lived in a one-roomed cabin at the foot of the glen, where in the spring, lying in bed, he could hear the herons gabbling and croaking after dark. $\mathrm{He}$ had worked for Thomas Geoghegan, the cousin of 


\section{WILD LIFE ON THE WING}

Cornelius, for forty years ; and now, pensioned off, kept the "rides" in the woods pruned, and stopped the "earths" against the visits of the Ballyoughter Hunt.

But in course of time, Thomas Geoghegan died childless, and the "ass-cairs" of the whole countryside followed his funeral. Cornelius, his cousin, whom he had not seen for twenty years, was his heir. They buried Thomas in the little cemetery in the demesne, among the crooked tombstones of the old Geoghegans-he himself had made a foxearth just outside the place. Cornelius Geoghegan walked behind the coffin as chief mourner, decorously valuing the timber and pasturage as he went. It was quite natural that he should not testify much grief for the demise of a relative whom he had seldom seen, and always disliked, but his future tenants, most of whom had tears running down their faces, loved him none the better for it. Later what respect they had for their landlord, for his name's sake, vanished, when they found that he not only pulled down the kennels at Ballongarry House to make room for his new garage, but did not even ride to hounds himself. (Thomas had held the mastership of the Ballyoughter Hunt for twenty years, and only gave it up when his rents 208 
grew less and his joints stiffer.) The following autumn brought to Ballongarry an English gamekeeper, who claimed rights as despotic as those which Andy Hogan exercised, and long and bitter was the conflict between them. Also, much timber was cut down; and though, truth to tell, the woods sorely needed thinning out, the people followed Andy Hogan, and denounced the deed. Andy was as superstitious as an Indian; and as the width of the baldric woven by the White Lady of Avenal testified to the prosperity of the family whose fortunes she watched over, so to Andy the heronry and the luck of the house of Geoghegan were mysteriously linked together. Therefore when only one pair of herons came to the old trees in the glen one still morning in January, he believed that the rest of the birds of last season's hatching boycotted the place solely on account of their dislike to the new heir.

One morning he chuckled with delight when he picked up a piece of blue eggshell under the tree.

"Shure there's more o' thim up there," he muttered, and tapped the trunk to see the old bird flap majestically off the nest.

Only the sunbeams saw the chicks wax from blind nakedness, which demanded nothing but 


\section{WILD LIFE ON ITHE WIN!G}

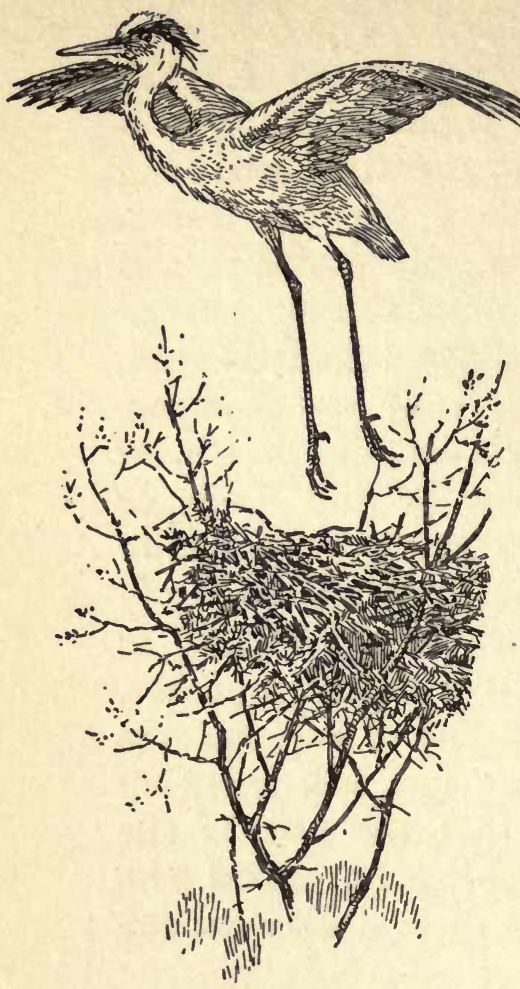

mother-feathers to cover them, to maturer fledgling dignity. Their food was frog-frog many times an hour throughout the day. Every time that the broad shadow swooped between the nest and the sun the chorus began, lowtoned at first, then increasing to a storm of coughing and yelping, as the gullet-full was distributed among the three gaping mouths. At first the fledglings' view of the world was limited to the sky overhead ; later they craned their necks over the nest rim and looked out over a purple undulating expanse of tree-tops to the bog under Slieve Corrig, whence the frogs came. From the other side one could see Dwerning, where the white tree trunks lay piled pitifully upon one another, and watch another and another totter and fall with its load of purple buds. By the time that the March gales 


\section{THE HERON}

came bellowing through the glen, the young herons were strong enough to balance themselves on their stilt-legs on the brim of their swaying cradle. Then while the beech buds grew fat in the April rains, they learned to leave the nest and perch on the branches near by.

By that time the woodmen had worked right up to Andy Hogan's cottage. The stream in the glen lay bald to the sunlight, and its banks were littered with chips and broken boughs, for Dwerning Wood was wood no more. Andy, tramping up the glen one April morning, grieved over it. The foxes had gone, the herons were going. Just below the Quarry Pool he came to where the live wood and the wood's ruins met. The herons' tree stood out by itself against the background of trunks and undergrowth, with the jetsam of the wood about its roots, like a column supporting the arch of a great temple. The winter gales had shorn away one main limb, but the other-as thick as an ordinary trunk-was now in young leaf. Two men stood under the tree, and one demonstrated certain measurements to the other, who was Cornelius Geoghegan himself. "So that when this tree is down, there will be plenty of room to enlarge the pond by 


\section{WILD LIFE ON THE WING}

digging out this piece of level ground ?" said the latter.

"No difficulty at all," replied the other, "the trees want cutting back to let in the light." "That shall be done," said Mr. Geoghegan. "That beech is half rotten already." He turned and met the gaze of Andy Hogan. "Begob, sorr! are ye goin' to cut down that tree?" stuttered Andy.

Cornelius had begun to find out that reforms must be wrought against the grain.

"Certainly!" he answered: "I have intended all along to enlarge this pond, and stock it with trout. That tree must come down tomorrow before the woodmen leave the place." Andy gazed at him speechless. "Shure ye're niver goin' to take down the tree wid the Corr iasc's nest in it? Me grandfather, and Misther Thomas, planted that tree."

"My good fellow," said Cornelius, in the tone in which he replied to importunate requests for alms, "kindly attend to your own affairs. When I wish to carry out improvements on my estate, I do not consult either birds or my, pensioners. That tree comes down to-morrow." Six months at Ballongarry had not prepared its owner for the outburst which followed. Andy spoke for three minutes, and in that time he had said everything that there was to 212 
be said, and had treated the subject from every point of view, without hesitating for a word. Cornelius Geoghegan was very angry as he walked away, but until he was out of sight he heard the reproachful voice behind him:- "and, bedam, the whole counthry would cry shame on him for cuttin' the auld tree his honour Misther Thomas had kept so careful."

"A most troublesome fellow," said Mr. Geoghegan, escaping down a side path.

The woodmen went to the heronry the next day, and Andy went there also. The old herons flew up at their approach, and circled screaming down the glen, while the young ones croaked foolishly. It took two hours' continuous sawing to divide the great trunk. Andy, with some others, stood by, and for all they were angry at the felling of the tree, from first to last they gave good advice on the best method of doing so. Late in the afternoon, when the ropes were fast to the branches the master came by, and they scowled at him. The old tree shivered under the ringing blows of mallet upon wedge: it tottered, and then the men leaped aside as gathering speed it fell headlong with a roar. When a man fells a tree, there is always a pause after the final crash. Men do not joke 


\section{WILD LIFE ON THE WING}

in that pause, whatever they may do afterwards, for, as it were, a gasp goes up from the woods as though a life had been taken; and the man feels that something which took a long time to make-something enormously larger and stronger than he-has gone down before his puniness.

So no one said anything for a minute, but as the men walked along the giant's. fallen length they came to the battered nest, and, flung beside it under the branches, the shapeless remains of two of the young herons. But the third fledgling lay a little apart, and Cornelius Geoghegan stooped over him with curiosity. To all appearance he lay as limply as his brothers, but as the hand was almost touching him, Andy Hogan caught a subtle gleam in the half-closed eye.

"Mind out, sorr," he exclaimed, and thrust Geoghegan aside. He was just in time, the neck straightened with a jerk, and the bill, long as a poignard and almost as sharp, shot up towards Geoghegan's face, but missing its mark ripped a red streak across his hand. $\mathrm{He}$ sprang back with a curse, and the heron calling harshly fluttered away.

Geoghegan walked off wrapping a handkerchief round his bleeding hand. When he had gone the men all agreed with Andy 


\section{THE HERON}

Hogan that "even the Corr iascs* would have the ugly face eaten off that feller for cuttin' down the old place, more power to them."

*

* * *

*

*

Long after dusk, Andy heard the herons calling up the glen. Later, he left his fireside and went out. That night, for the first time for many a year, the stars' reflections glimmered in the Quarry Pool, and he sat down on the trunk of the herons' tree to watch them. Then he found that he was not alone. A grey blur on the bank took shape in the gloom, stilt-legged and melancholy. It flounced away when Andy moved, but this was the little heron's first day out of the nest, and earth and water were alike new to him. Therefore he flapped into the

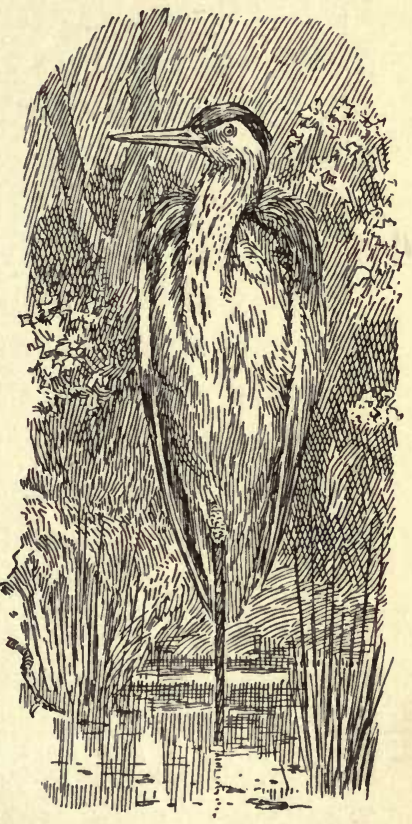
angle of a rock, and tried impotently to flutter his way through it. When Andy's coat fell over

* Corr iasc $=$ heron. 


\section{WILD LIFE ON THE WING}

him, hot and stifling, shutting out the sky, he thought that it was death, and collapsed limply under the folds. But when a chink gaped between collar and lapel for an instant, the wicked bill darted out and dented Hogan's boot. "Bedam! he's a great fellow," chuckled the old man, stamping his tingling toe.

The captive spent the night in the lean-to beside the cottage. Andy slept late the next morning, and was awakened by a lusty threshing of wings outside. The furze which closed the lean-to was battered awry, and the fowls loitered outside. One strayed a little nearer, and instantly the heron struck through a chink, and missed his mark by a hair's-breadth; the hen sprang away with a terrified squawk and Andy looked thoughtful.

Later, he gave his captive a dish of water and a piece of bacon, but the heron rejected both. Even a frog failed to move him; he turned a cold and apprehensive eye to all blandishments, and stood huddled in his corner until evening. It was dark in the lean-to when the cat crept in. It was a shock to her to meet the cold regard of the heron, and she spat softly. $\mathrm{He}$ was very still-no bird that she had ever stalked had dared remain still under her eye for long, and she stole nearer. The heron's bill met her shoulder and drove her to the 2 I 6 


\section{THE HERON}

door. Twice she jumped at the furze-bound hurdle and fell back. The third time it slipped down with a clatter and she vanished. With dawn the captive saw an oblong of sky, which the furze had blocked before, and strode towards it. The fowls were out already, and ran after him aggressively.... Half an hour later Andy found him preening himself and at his feet two dead chickens.

"Begob! it's time you went, me lad," growled Andy and walked towards his escaped prisoner. The heron spread out his great wings and half hopped half flew up the glen. "Shure there's still a heron in Ballongarry," said Andy Hogan.

II

The little heron had lived in bewilderment among miracles for the past two days, but now, standing on the threshold of the woods, his being responded to their stimulus, and he began to take his proper place in the scheme of things. He misdoubted the tree trunks at first, for they looked like men, but as they did not molest him, he began to pace sedately between the stacks of timber. It was a very bright and full world, but nothing in it took any notice of him, until he came to the tits. 


\section{W ILD LIFE ON THE WING}

They were exploring a heap of faggots, and being surprised at his melancholy figure, one and all, great tit, blue tit, coal tit, and the bob-about gold-crest, their camp-follower, all said so, until the heron was confounded, and cowered in the undergrowth until the storm had passed.

The sunshine left the glen, and damp mist hung among the trees. Then the stream in the hollow made such a pother that the heron began to listen. Water, still or brawling, speaks very plainly to the people who are to inherit the waterways, and the heron strode sedately towards the music. The path was rough and strewed with waste wood, and as yet he was unhandy with his legs-they seemed a trifle too long. Also, in spite of his size and dignity, he was nothing but a great overgrown baby, very new to life, trusting where he should have trembled, and dreading bogies in innocent places. The dim pool suddenly lay before him, shot with ripples where the newts rose. Under his foot a frog writhed and leaped. He sidled towards it delicately and watched it. Frog he knew well, but limp, disembowelled frog, ready for swallowing. That frog could kick put a new complexion on the matter, and he struck it suddenly thrice, till it lay pulped on the mud. 2 I 8 


\section{THE HERON}

That whetted his appetite for more-he tried a slug next-then a worm. After that, temporarily crop-filled, he huddled under a thorn bush and dozed.

By morning he was ravenous again. He had lost his voice in Hogan's yard, but out in the woods he found it, and terrified a moorhen by clamouring unavailingly for food. Gradually he realized that, as he walked, slimy things started out of the mud when it trembled under his feet, and so he learned to feed himself.

The woodmen came to cut up the beech-tree, and he watched them philosophically, but he had learnt that men were dangerous, and he would not let them near him. "That's the lad killed two hens on Andy Hogan," said one. "Shure I'd have wrung his neck for him."

"Begob I was near doin' it, too," said Andy, emptying his pipe, "an' he near had the cat killed, too. But me ould father would always have there was no luck about the place when the herons left it. There was no nests in ' 98 whin the house was burnt, and they niver came near the year Misther Michael (God bless him) left the counthry. So I thought I'd give this chap a chance, and faith, he's come back to the old spot again."

* * * * * * * 


\section{WILD LIFE ON THE WING}

The young heron loitered by the pool until he was comparatively strong on the wing. Then he saw the open country, from the demesne wall to the foot of Slieve Corrig. As men draw roads and railways on their maps, so the herons mark theirs with pools and watercourses -the land between is waste and profitless; the sluggish streams, studded with wider pools, lay across the bogland like rosaries of silver beads. There was a little west wind which blew round the breast of Slieve Corrig and ruffled the still pools. The heron felt the mud squelch up, and the tadpoles wriggle away between his toes. Truly a land of promise where it was good to be alive, but was there nothing to eat in it? He was King of the Bog, but that first day he was fated to play jackal to the bank-rat's hunting. He saw the old moorhen whizz past him like a driven leaf, but it conveyed no meaning to him, nor did the splash of the rat's foiled spring in the rushes. How should the moorhen's chick recognize his long legs among the iris spears where they stood, thigh deep? It charged into them like a little torpedo, and the shock brought it, gasping, to the surface. Too late it dived again, but the heron whisked it up, bayoneted. So much for the tale-now for its sequel. He made nothing 


\section{THE HERON}

of a frog, but then a frog's descent to digestion is, so to speak, self-lubricated ; it is otherwise with down and claws, and this was a well-grown chick. The heron regretted that meal many times during the next halfhour-indeed once or twice it was doubtful whether he would ever eat another. But the difficulty gradually disappeared and left him pensive, and exhausted with the exertion of admitting something which, if it did not bear quite the same proportion to his gullet that a camel does to a needle's eye, was nevertheless many sizes too large for the passage, and interfered very seriously with his breathing sometimes.

But ultimately, very content, he went to sleep, back to wind, to the lullaby of the snipes' bleating overhead. Under the swish of the wind the rushes bowed their homage. For the Corr iasc is King of the Bog, and that night he came to his own.

\section{III}

Now the summer doings of the Corr iasc concern us not overmuch, for the days are long and pleasant, with abundance of sunshine, and good feeding among the bush grass in the bog, or in the woodland streams of Ballongarry, 


\section{WILD LIFE ON THE WING}

the demons of cold and famine sleep for a little while, and for the heron, who had found nothing in the wild large enough to hunt him, there was nothing to be done but learn the geography of the waterways of the country, and grow fat. So while he stands thigh deep a-fishing in the bog, I will take up that part of their joint tale which concerns Andy Hogan.

All the summer he carried on a feud with Thompson, the gamekeeper, over the respective rights of foxes and pheasants. The keeper dared not declare open war as yet, for he feared public opinion, but he never failed to report Andy's delinquencies to his master, who heard them readily enough; for Andy had never troubled to ingratiate himself with his new employer, and met every improvement with stubborn resistance: "It was niver done that way in Misther Thomas' time."

Early in the summer, while the water was low, the Quarry Pool was stocked with little trout, the dam and sluice, through which the water now escaped, in their raw newness were a conspicuous sight at the head of the glen, and the old man loathed them, as Sunday by Sunday he passed them on his way to hear mass. 


\section{THE HERON}

It was in September however that matters came to a head. At the beginning of the month the Ballyoughter hounds came to Ballongarry, and in spite of many hints to the contrary Andy went round and "stopped" the earths on the preceding night. In the darkness he tumbled over a heap of newly turned earth, and, digging deeper, exhumed a fine fox cub with a hole blown in his spine. Then he knew what the report of a gun early that morning had meant.

To draw the woods, the hunt rode by Thompson's gibbet, an elm-tree laden with unwholesome fruit-a garland of stoats, a cat or two, and shattered magpies in a row. Thompson himself plodded in the rear with Andy Hogan and the crowd of country boys whom news of the hunt had brought together. Suddenly there was an outcry among the hounds ahead, and the horses jostled back in the narrow lane. The men behind could see nothing of the reason for the commotion, but they heard the Master say stiffly: "It is most satisfactory for the hunt to know that the Ballongarry keepers do their work so thoroughly." The

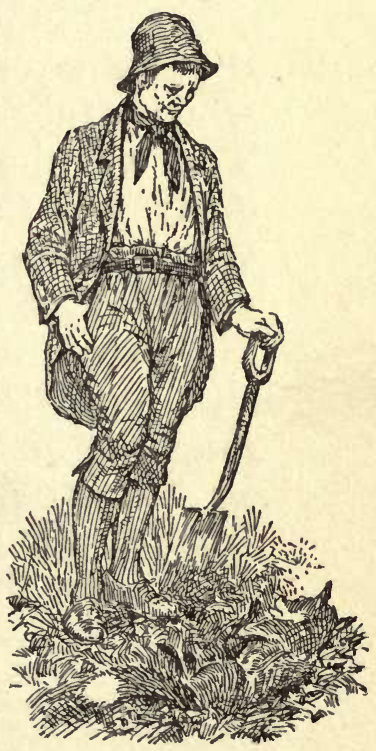




\section{WILD LIFE ON THE WING}

cavalcade passed on, but when the pedestrians came abreast of the elm, there hung upon it - plain for all to see-a dead fox.

"Shure the dogs thought that they had that lad cot easy," said Andy Hogan innocently ; but the keeper, speechless with wrath, noticed that

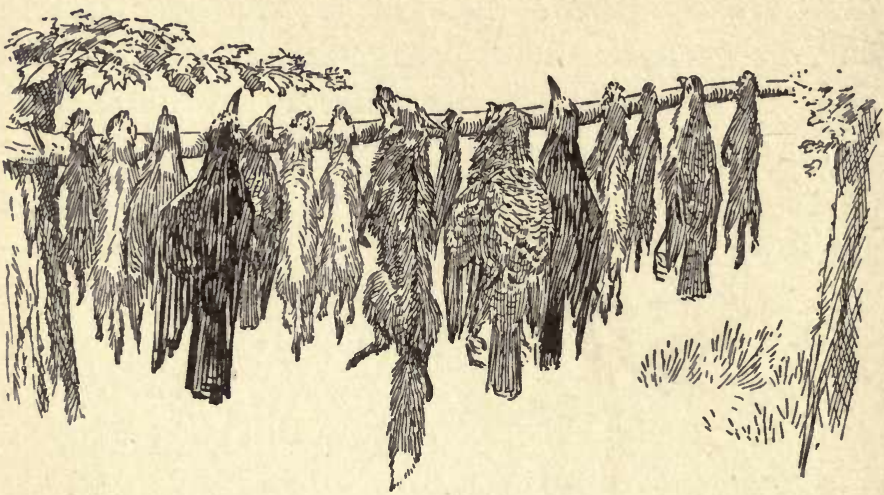

the smears of clay on his coat matched those which daubed the fox.

That was the end of a long series of reprisals. Andy was told that the cottage in the glen was to be turned into an engine-house for the dynamos of the electric light which $\mathrm{Mr}$. Geoghegan meant to install at Ballongarry, and that he must move out. Hogan snapped his fingers at first, and replied that he would live to be "waked" in the house that his honour Misther Thomas had given him; but when he found that the matter was serious, he abused 


\section{THE HERON}

Cornelius Geoghegan with the full extent of his vocabulary, threw out dark hints of further vengeance, and finally flung the porridge pot at the messenger. Mr. Geoghegan believed that his personal safety was threatened, and evicted his rebellious tenant. Thus Andy went to live in a one-roomed cottage on the Gap under Slieve Corrig.

It was a grey autumn day when he left Ballongarry. The Quarry Pool was full of water after the rain, and as he went by a big blue heron swung up with a shriek. The water dripped through the leafless trees in the woods, and the strong wet smell of fungoid things hung over everything. As he walked after the jolting donkey-cart which contained his few pieces of furniture Andy's heart was black within him. On the high road, Geoghegan's new Mercédès panted and hooted up the hill behind him. Andy feigned deafness, and took a dreary pleasure in obliging it to slow down to pass him. He went by with averted head, and scowled when the mud from its wheels splashed him.

The new cabin was mudwalled and draughty. He crouched over a smoky fire and listened to the wind singing chilly songs through the chinks. Before he turned into bed, he looked out to the west; silhouetted against the sky, 


\section{WILD LIFE ON THE WING}

stood the huge bulk of Slieve Corrig, and down below lights twinkled from Ballongarry House. From somewhere in the darkness a lapwing cried, and from the bogs a deeper shriek answered. Andy heard the swish of broad wings over the cottage, and then the Corr iasc passed calling towards Slieve Corrig.

"Bedad! he's had to leave the ould place as well as me," said Andy Hogan. And the firelight lit an evil gleam in his eye.

* * * * *

*

By his own act, Cornelius Geoghegan had introduced a master-poacher into his woods. Previously Andy had poached to fill his own pot, but none of the other men in the neighbourhood had dared to do so. The farm lads ploughing in the "Forty Acres," durst not set snares in the hedge during the dinner-hour ; on Sunday afternoons there was no fox-coursing in Ballongarry. Now Andy poached flagrantly, and for revenge. He disliked fishing, but for many nights he squatted under the old thorn by the Quarry Pool, watching his float patiently, and what he caught he buried. It was no wonder that the numbers of the imported trout steadily decreased, for often on the long warm evenings another and most accomplished angler visited the place. This was the Corr iasc, and he seldom went away hungry. - Andy had 226 


\section{THE HERON}

always spent much time alone in the woods, and the birds and beasts were companions to him. Unconsciously he endowed each kind with a character, and now the solitary heron's nature seemed to tally with his own. But the chiefest bond was that the man who had cut down the Corriasc's tree, had turned Andy out of his house. Andy began to have a fellow feeling for the Corr iasc, about this time.

Thompson, the gamekeeper, used to notice the poacher's footprints in the trampled clay round the pool, and one evening he took his gun thither. It was very still in the glen, and the wood-pigeons cooed until it was too dark to see the colour of the trees. The keeper sat still in the shadow, and the rats came out and scurried along the bank. Only there were none to be seen under the thorn bush on the other side. Perhaps it was a startled rat running to covert which had stirred the calm surface into ripples just as the keeper approached.

By and by there was a shriek, and the heron flew up the glen. He circled twice round the place out of gunshot, and then alighted suspiciously on the dead limb of a pine. The keeper brought his gun to his shoulder slowly, for the light was failing, and he dared not risk a hasty shot. But even as his finger crooked round the trigger, there was a splash which 


\section{WILD LIFE ON THE WING}

woke the echoes in the glen, and set the surfaces of the pool dancing. The heron dashed from his perch, and the shot whistled harmlessly over his head.

"Damn it! what was that ?" growled the keeper. "It was too big for a fish."

The ripples subsided gently, but he suddenly became aware that there was one old tree stump less on the opposite bank. There was a blanched spot on the grass whence a stone had been recently lifted, and close by he stumbled over the peg of a night-line. The keeper realized that more than one poacher had escaped scotfree that night; but the Corr iasc never suspected who had saved him.

\section{IV}

In the angle of the mountain where Slieve Corrig curved down to meet the lower Slieve Gar, there was a little lake where the mountain sheep and foxes went to drink, and which reflected nothing else from week's end to week's end except clouds and stars, unless the Corr iasc went fishing there. In the still November mornings, when the valleys were so brimful of mist that only the tops of the higher hills stood out like islands, the smoke from Andy Hogan's chimney rose straight up the hillside almost to 228 
the lake. Most days, when Andy himself climbed thither to cut furze or snare rabbits, the heron would flap up majestically, and alighting on the hillside a little way off, watch him out of sight.

It may have been the November mists which stiffened the old man's joints, but day by day he walked up the mountain more slowly, and very often his lips moved as if he were talking to himself. Whenever he saw the Corr iasc fly up, he used to pull off his old hat and flourish it, shouting: "Good luck to ye." Very often, when fishing in this little lake at dawn, the heron saw Andy toiling up the mountain-side from Ballongarry, with his frieze trousers torn by brambles, and his pockets full of rabbits. Andy was always talking to himself at these times, and only broke off to shout : "Begob, there's still a heron in Ballongarry !"

Then in the evening, when the heron flew up from the bogs, he used to swerve aside at the bend in the road where Andy, with his pipe aglow, leaned against his door and looked at Ballongarry. He commonly talked so loudly at these times, that the Corr iasc in the tarn could hear him. Once when a belated donkey-cart was passing down the road, Andy was shaking his fist at the lights of Ballongarry, and speaking so thickly and so fast that the man in 


\section{WILD LIFE ON THE WING}

the cart thought that he had been drinking, and rallied him about it as he bade him "goodnight." Andy came and leaned upon the shaft.

"Bedamn!" he whispered, " there's one below is atin' and dhrinkin' wid the pleasure o' disoblingin' a poor chap like me, but there are those up there have their eye on him to-night." And he spat towards Ballongarry. The other laughed to humour him and passed on; but the heron, fishing sedately, kept a wary eye on the light in the cabin window which burned until long after midnight. If he had known why it burned he would have regarded it more warily still : Andy sat up until long after midnight polishing and repolishing his old gun.

About this time the rumour spread that Andy Hogan was "quare." If any one visited him he met them either with vile abuse, or else with mysterious hints about the "things on the mountain above," and gradually the country people left him to himself.

Men who live much with abstract things, of either their own conception or other people's, do not realize what the world of realities is to the unlearned and to children, to whom the swish of the wind, and the weather, and the dripping of water, and the solidity of things, are not manifestations of laws whose mystery: has 


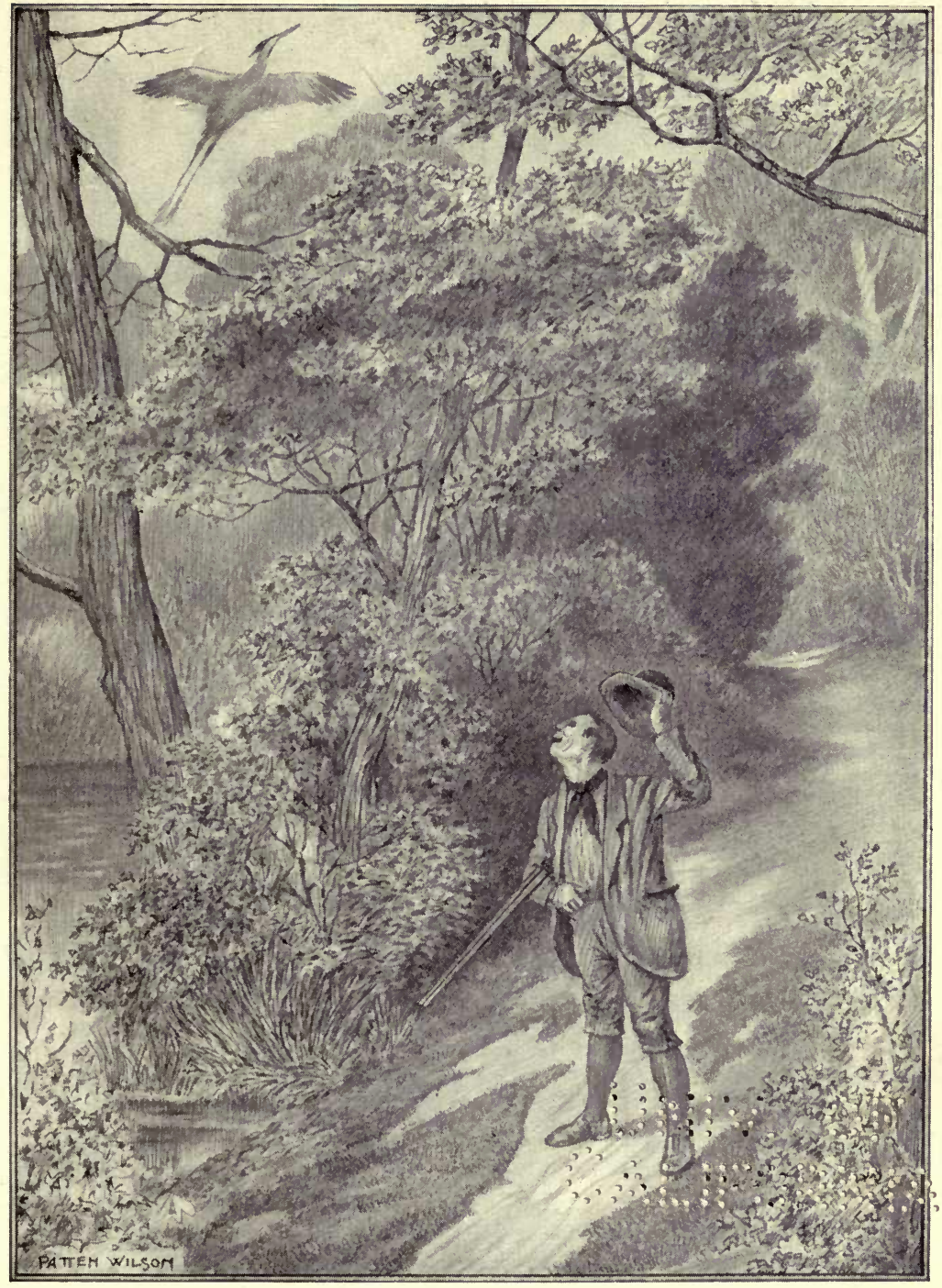

ANDY WOULD PULL OFF, HIS OLD HAT 



\section{THE HERON}

been staled by recurrence, but miracles, whose incomprehensibility is all the greater for their repetition. And where so common a sight as a star is an inexplicable wonder, there is room and to spare for things which wiser men have roped out. To those who go to live among them, the strength of the hills is apt to become an actual force, overwhelming and rather terrible. When Andy left the cottage in the glen, the sough of the wind in the chink, and the patter of the rain on the roofs were too real to be questioned-he

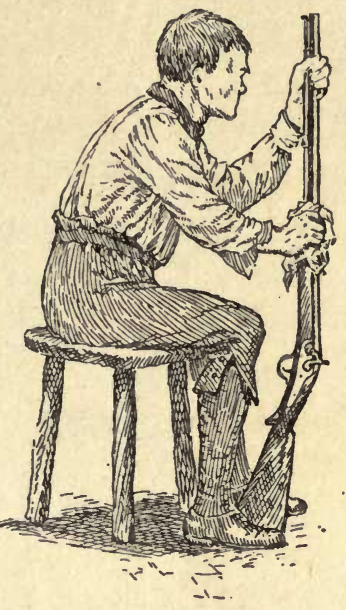
never thought about them at all; but on the Gap during the lonely evenings, he began to meditate about these and other things, more than was good for him. He could not have told which was the exact day when the wind under the door became a whisper, and the stars over Slieve Corrig, eyes winking with evil suggestion; but the transition was quick, for defences go down easily at seventy years. Andy had only lived a few weeks on the Gap before he knew that the place was peopled with devils. They came out at sunset with 


\section{WILD LIFE ON THE WING}

the flighting of the plover, and clambered about the rocks and heather coverts until dawn. As he lay in bed at night with the fire banked, and the fowls clucking drowsily from their perch, he knew very well that devils came and mowed at him through the window, and blew wicked little songs down the chimney. By day he supposed that they turned into foxes and hares and quarrelsome larks on the mountainside ; but sometimes a cold mist settled upon Slieve Corrig all day, so that he could not see the lowlands at all, and then the devils never left the place but swam about in the fog, and gambolled round the tarn. At first he was afraid. He brought holy water and sprinkled it round the place, and he crossed himself when he heard them clambering up the roof, but these devils were stronger than water or sign. Especially they loved the tarn whence he fetched his water every day. He could not see the bottom of that tarn for crawling devils, and even in the sunshine they winked at him when he staved long enough. More and more came about him at night. He heard them chuckling outside, and used to draw the ragged coverlet about his ears: he brought his goats into the kitchen for company, and put a cross of holy water above the hearthstone. He always slept with his loaded gun beside him. A neighbour 


\section{THE HERON}

visiting the house one day noticed that the window-frame was pitted with holes, and wondered why. The Ballongarry Corr iasc could have told him how, as he stood frog-catching in the tarn, a gunshot pierced the peace of the night, and drove him away in fear ; but only Andy himself knew what evil thing leered at him through the pane.

Later, on stormy nights, the devils came down the chimney, and warmed themselves at the fire, regardless of the cross. They talked to one another about this little house and how it and all who lived in it belonged to them, and how they hated the great house at Ballongarry, and that another devil called Cornelius Geoghegan lived there. One night, in a cold sweat, Andy shot at one of these knowing devils, and when the smoke had cleared away it was gone, and he was glad. But in the morning he found that the evil things had broken the leg of one of his goats. Andy was very much grieved and cursed the devils as he bound up the wound, and gave the poor animal a mash, for he loved all beasts and birds.

There was only one thing which. could keep away the devils, and that was the whisky in the cupboard. Andy had never drunk much before except on fair days and such like, when he had sometimes " dhrink taken." He drank 


\section{WILD LIFE ON THE WING}

deeply one night however, and then he slept so soundly that he never saw the devils at all, although in the morning he felt sure that they had been there. But gradually even whisky did not avail to keep them off although it took away his fear of them. He even became accustomed to them, and did not shoot at them any more, but listened to that crafty demon who suggested that he should fire at other things instead. And whereas he had previously been afraid to go out after dark, now he used to spend half the night wandering about the mountain-side, and come back to find his house full of spirits, and he laughed and sang to see them. Most often he used to sit by the tarn, and watch the calm reflection of the stars broken up into flickering fires by the wind. But he thought that it was devil's light.

The Corr iasc used to fish there. By day he was a heron no doubt, but by night he was a devil, also. A still devil, who stood hunched, watching lesser devils play. At noon these might be frogs or roach, he told himself, at night - he knew better, and so did the Corr iasc devil. Andy used to watch him for hours at a time, when the hillside was so still that the lip-lip of the water round the long legs could be heard plainly when they moved and set the starry devils in the water dancing in rhythm to 234 


\section{THE HERON}

their steps. Then sometimes Andy went home silently at cock-crow, and drank more whisky to chase the winter damps from his limbs; but more often he clapped his hands, and yelled with delight to see the grey Corr iasc flap majestically from the tarn.

Andy was speaking to a turf cutter one dayhe seldom spoke to other men now-when the heron flew overhead. Andy broke off in what he was saying and gripped his companion's arm. "Do ye see him ? Do ye see him ?" he whispered, cunningly.

"Shure, it's only a Corr iasc," said the other, wondering.

"Bejabers ye're right, Casey, ye're right. 'Tis a Corr iasc shure enough, and not a divil at all. A divil wouldn't stand the holy wather."

He went away, muttering; and the word went round anew that Andy Hogan was mad.

He used to go down to Ballongarry every day. At first there were no devils there, but later they followed him thither, and walked with him all the time. Most especially he saw them in the big Beech Wood, where the grey trunks rose stately like ghosts, and the leaves under foot were wet and red. All the time when he was not talking to the devils he was thinking about Cornelius Geoghegan and hating him. Gradually his poor fear-ridden illogical brain could 
WILD LIFE ON THE WING

only contain one other thought, and that was the Corr iasc. He became obsessed with the idea that the whole remaining prosperity of Ballongarry depended on the preservation of the heron. Twenty times a day as he patrolled the woods he muttered to himself: "There's only one lucky Corr iasc left in Ballongarry now, but, bejabers, we'll keep him." And night after night he went down to the pool to see if the bird were safe.

In the harder weather strange herons came down to the bogs, but Andy seemed to know intuitively which was the native bird. Sometimes too the Ballongarry heron used to go away for days at a time, and then Andy used to visit the keeper's gibbet, dreading to see the grey still-legged form among the mummied remains there, but sooner or later the Corr iasc came back to his old haunts.

Probably it was much brooding over the heron's doings which caused the conception of Andy's great idea, but it was an interview with Cornelius Geoghegan which hurried its gestation. Geoghegan told him that his rabbit snaring and illicit fishing expeditions had been brought home to him, and that if he came into Ballongarry again he would be prosecuted.

That night Andy walked about on the mountain until dawn, and his fingers were blue and 236 


\section{THE HERON}

his coat wet with mist ; but he did not feel cold, for choirs of devils went with him and talked to him, pointing to the lights of Ballongarry.

Then his great idea was born when he saw the Corr iasc fly screaming westwards from the morning star, when the vigil, and the glamour of the "false dawn," and the devil talk had made him a little light-headed.

"As long as there was a Corr iasc's nest within the bawl of an ass o' the place, there should be a Geoghegan in Ballongarry." On the slope of the mountain he saw five. They stood in a wide circle, gravely, without sound or movement, like ghosts of birds. Only when he crawled from his lair among the gorse did they take wing and flap silently to another knoll further away. They alighted independently and stood silent and hunched as before; but before Andy had reached his cabin, he saw that their circle was closing up again. Then he knew what it meant, for the fox on the hill had been barking all night, and a ewe on Slieve Gar had dropped her lamb. It was the new year, and the herons were pairing.

A sitting hen upon his bed clucked softly as he threw himself down beside her. He was so tired that he slept without the soothing of the black bottle, and at last he began to dream. He dreamed that he saw Cornelius Geoghegan 


\section{WILD L'IFE ON THE WING}

sitting by the tarn, and that he took his gun and shot at him through the window. The gun did not make any noise, but from where the man had been sitting a heron got up and soared away, and when he looked again the place was empty.

Andy woke so gently that at first his awakening seemed like a continuation of his dream. He felt strangely content, and wondered whether it was only that his cold wet hands had dried during his sleep. Then he remembered that the man whom he hated was dead, and with great joy thereat hot in him, he went to the door. The goats with full udders bleated to be milked, and the fowls ran up to be fed, but for the first time in his life Andy forgot them. The herons had left the field. Three were gone, but two stood fishing beside the tarn. He knew that these were the Corr iasc and his mate, and that though the herons' tree was cut down, yet they might still make a nest in Ballongarry. With the black bottle beside him, his scheme grew slowly from the mustard seed of his dream. Logically it was unimpeachable. $\mathrm{He}$ marvelled that he had never thought of it before : "While there was a Corr iasc's nest within the bawl of an ass of the place, there should a Geoghegan at Ballongarry" - the deduction was simple. If there were no Corr iascs 238 
-Andy brooded over this for three days while he sat in his door, polishing his old gun.

The Corr iasc and his mate fished on the sea flats. The moon was full, and the tides fell nightly until the shoals were bare, and left slimy things stranded in the mud, for the duck and the curlew and the widgeon to dabble for under the stars. But one night the weeds floated just awash, and the next evening the wild fowl went to the bogs to feed. The herons fished alone on a sandy spit. But when they moved, the flounders darted beyond their reach in an eddy of sand, so that the herons were hungry nor likely to be fed.

To the seaward the rollers toppled and crashed in rhythmic diastole and beat the sand-banks smooth, but in the shelter of the spit the water was placid and still, shimmering with the reflections of the sky. A row of widgeon, like a string of black beads, rose and dipped on the invisible swell and the gulls flew out to sea leisurely with the light upon their wings. The crimped surface of the mud glistened in the sunset; beyond were the sandhills and then the open country with churches and houses upon it, $\operatorname{dim}$ as Atlantis in the mist. 


\section{WILD LIFE ON THE WING}

The Corr iasc made three strides and took wing. Ten beats in that still air carried him to the sandhills. There he waited and called. She was a grey blur against the bright sand and water, but before he had uplifted his great voice twice she sailed up beside him. They mounted together in spirals, so high that they could see the golden spot where the sun set long after the earth was dark. They flew silently for the most part, but now and then the Corr iasc croaked contentedly as he recognized old landmarks. So they came abreast of Slieve Corrig. A glimmer of water on the mountain-side showed the tarn, lying wind-ruffled and naked to the stars. There was a light in the cottage on the Gap, but when they came near it twinkled and went out. The Corr iasc would have alighted by the tarn, but something moving crabwise over the heather made him swerve aside, and as he did so he caught the glint of the young moonlight upon metal. He wheeled back to Ballongarry with his mate behind him.

They went to the Quarry Pool, a profitable fishing-ground and well sheltered. The face of the night began to change and cloud-drift floated over the moon; but the wind was warm and the frogs, who had taken their winter's sleep in the rocks, awoke and sought their spawning-grounds. 


\section{THE HERON}

They had fished there for an hour or more when the female heron flew up suspiciously, and flapped screaming away into the night. The Corr iasc raised his long neck, which was sunk between his shoulders, and listened. The glen was dark and very silent, but by the strange telepathy of the wild he knew that somewhere something was watching him. He took no chances. He flew heavily across the pool and alighted, every nerve a-tingle, on a rock on the other side.

If his ears had been sharper he might have heard a disappointed snarl from the bushes as a levelled gun was lowered; but as it was, only a drowsy blackbird fluttered as Andy Hogan slid down the steep bank to the path screened by laurel bushes.

The heron was dimly visible against the rocks, but out of gunshot. Andy began to crawl softly through the bushes. Twenty yards further on, the little path opened on to the carriage drive, and he wriggled noiselessly over the turf. The road ran within a few feet of the edge of the old quarry, from which it was fenced by some wire palings screened by furze bushes. Andy worked himself along with infinite caution, never allowing his head to appear against the sky, and as he crawled evenly and noiselessly he cursed Cornelius Geoghegan. His whole heart 


\section{WILD LIFE ON THE WING}

and soul were concentrated on his object as he peered over the edge of the quarry into the pool. Every movement of the bird thrilled through his being: he watched so intently that to his wearied eyes the bird seemed to grow large and luminous in the gloom. He thrust the gun

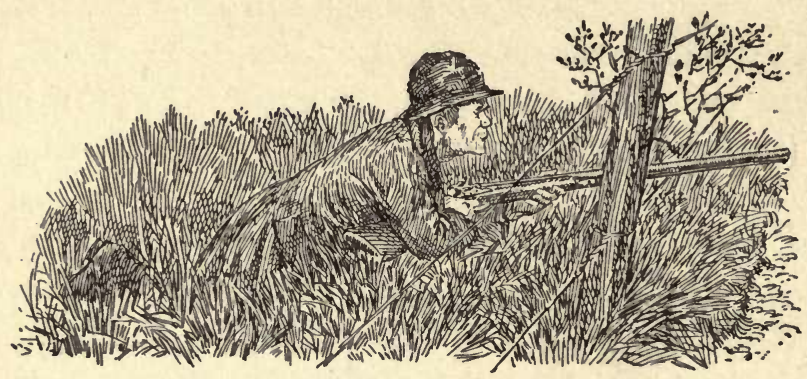

barrels through the fence. His eyes were dim and rheumy as he took aim. He had waited many nights for this, but now that he had his chance he did not feel exultant, but only very content. The devils who had followed him from the mountain seemed to have left him now. He was quite sane. His gun was loaded, and he crooked his finger round the trigger, but though it seemed to him that he pressed hard yet he could not fire it. His hands trembled so much that the gun barrel jangled the wire paling and he wondered that the heron-devil did not hear. What would happen when he fired? Would the Corr iasc die ? or would he 


\section{THE HERON}

shriek and bleed? It was a very fine and honourable thing-to kill a devil, but for all that he lay in a cold sweat. For the first time in his life the quiet of the woods was awful, and he feared to move lest something should clutch him from behind.

How long he lay like this dallying with the consummation of his wish under his finger, as it were, he did not know; but the heron had settled down to his fishing reassured when above the continual murmur of the frogs in the pool, sounded the distant throb of a motor-car. The Corr iasc did not hear it at first, but the man gritted his teeth together. The road wound away across pasture land, and suddenly against the darker mass of a beech wood beyond twin lights swung into view. Blinking stupidly, Andy watched them rush towards him down the slope.

He forgot all about the heron. He put up the gun and took aim between the blazing headlights. He never paused to ask himself whether he were sure who drove the car. He knew. He suddenly felt quite sober and collected. The lamps of the great Mercédès threw an arc of light far ahead. The Corr iasc saw the sudden glare and swung up from the pool, but Andy unflinching watched them rush towards him. They were fifty yards away ... thirty 


\section{WILD LIFE ON THE WING}

.. . twenty-he tightened his teeth and fired. There was a startled yell, and a crash of splintered glass, but the car still came on. Its lights shone above him like a pair of eyes, and he fired again, and saw one go out. Then, as the automobile swerved off the road right upon him, he clubbed his gun and struck at it savagely. ...

The Corr iasc, wheeling down the glen, heard a cry and a great splash, then the second light went out, and crying harshly to his mate, he left Ballongarry. 


\section{HIGHWAYS AND BY- WAYS OF THE ZOO- LOGICAL GARDENS}

\section{By C. INNES POCOCK}

Containing a Frontispiece in Colour and 32 Full-page Illustrations from Photographs

Small square demy $8 v 0$, cloth, gilt top

(By post, 5/4)

PRICE 5/- NET

(By post, 5/4)

"Never in the world's history has sympathy between man and animals stood for what it does to-day-that, of course, by reason of man's education and ubiquity - and nowhere else could we see a more pleasing result of the combination of these factors than in the Zoological Gardens, where the collection numbers about four thousand specimens, including almost every wild animal known, from an elephant proper to an elephant-shrew."

Such are the author's opening lines in this book. The writer, desirous of further familiarizing animal life, mentions not only such creatures as, by reason of their size or colour, readily catch the eye, but also the quaint, curious, and lesser known little animals that may truly be said to belong to the bypaths of life. These notes and descriptions show the charm of style, sympathy, and, above all, fine powers of observation which characterize the author's writings; moreover, Mrs. Innes Pocock is peculiarly fitted for the work to which she sets her pen, inasmuch as she writes with a knowledge of her subject born of twenty years' experience, and, as the wife of Mr. R. I. Pocock, F.R.S., the Superintendent of the Zoological Society's Gardens, she has unique opportunities of becoming acquainted with so many forms of animal life.

ADAM \& CHARLES BLACK, 4,5 \& 6 Soho SQUARE, London, W. 


\section{THE MOOSE}

\section{By AGNES HERBERT}

AUTHOR OF "THE LION" IN THE " LIFE STORIES OF ANIMALS" SERIES

Containing 8 Full-page Illustrations by Patten Wilson

Small square demy $8 v 0$, cloth, gilt top

(By post, 5/4)

PRICE 5/- NET

(By post, 5/4)

In the modern school of writers who treat animals with peculiar sympathy and insight, there is none who has come more quickly to the front than Miss Agnes Herbert : her wide practical acquaintance with the haunts of big game all over the world has shown her the shy creatures of the plain or jungle as they really are. Her book on the lion drew the attention and admiration of big-game sportsmen, but we venture to think that in the life of the moose she has surpassed herself. This enormous creature, living in the wildest parts of Alaska and Canada, has never failed to evoke interest and enthusiasm in those who have had the luck to come across him. Here we have him shown with remarkable tenderness and insight in the thick forests and glades of his homeland. Not only is the moose himself, who necessarily occupies the forefront of the picture, drawn for us so vividly that we feel him to be palpitating with life, but all the hundreds of lesser creatures peopling the woods and wilds make a background full of animation. The book is one which no lover of the wild should miss.

ADAM \& CHARLES BLACK, 4,5 \& 6 SOHO SQUARE, LONDON, W. 


\section{"PEEPS AT NATURE"}

Edited by the Rev. CHARLES A. HALL, F.R.M.S.

EACH CONTAINING I6 FULL-PAGE ILLUSTRATIONS, 8 OF WHICH ARE IN COLOUR. LARGE CROWN 8VO, CLOTH. PICTURE COVER

(By post 1/9) PRICE $1 / 6$ NET PER VOLUME

(By post $1 / 9$ )

\section{LIST OF VOLUMES}

WILD FLOWERS AND THEIR WONDERFUL WAYS

By the Rev. Charles A. Hall, F.R.M.S.

BIRD LIFE OF THE SEASONS

By W. Percival Westell, F.L.S.

BRITISH LAND MAMMALS

By A. Nigal Simpson, F.Z.S.

BRITISH FERNS, GLUB-MOSSES, AND HORSETAILS

By Daniel Ferguson, M.A.

BRITISH BUTTERFLIES

By A. M. STEWART.

NATURAL HISTORY OF THE GARDEN

By W. Percival Westeli, F.L.S.

ROMANGE OF THE ROCKS

By Rev. Charles A. Hall, F.R.M.S.

THE NATURALIST AT THE SEASHORE

By RICHARD ElmhIRST, F.L.S., Superintendent of the Millport

Marine Biological Station.

REPTILES AND AMPHIBIANS

By A. Nicol Simpson, F.Z.S.

POND LIFE

By the Rev. Charles A. Hall, F.R.M.S.

COMMON BRITISH MOTHS

By A. M. STEWART.

COMMON BRITISH BEETLES

By the Rev. Charles A. Hald, F.R.M.S.

PEEPS AT THE HEAVENS

By the Rev. JAmes BaIkIe, F.R.A.S. Containing 16 Full-page Illustrations ( 8 in Colour). Cloth, Picture Cover. Price 1s $6 \mathrm{~d}$ net.

ADAM \& CHARLES BLACK, 4,5 \& 6 SoHo SQUARE, London, W. 


\section{THE OPEN BOOK OF NATURE}

A Book of Nature Study for Young People. Containing 16 Full-page Illustrations in Colour, also 114 Reproductions in Black and White from Photographs, as well as numerous Illustrations in the text. Large crown 8vo, cloth. Price 3s 6d net (by post 3 s rod).

"This pleasantly written book is well fitted to arouse in young people an interest in the study of Nature, while many of older growth will probably find in its pages much that is not unprofitable reading. . . . The chief difference between this book and most others on Nature study is the prominence which it gives to geological subjects. .... Copiously illustrated." - Athenaum.

"Mr. Hall's agreeable, interesting, and instructive volume. . . It should attract not only young people, but anyone looking for an easy introduction to Nature study." Scotsman.

\section{HOW TO USE THE MICROSCOPE}

Containing 20 Full-page Illustrations from photo-micrographs, and many line drawings in the text. Large crown 8vo, cloth. Price is $6 \mathrm{~d}$ net (by post is gd).

"There are many cheap books on the microscope before the public, but we do not know a better than the one now under consideration."-Scottish Naturalist.

"It is, however, the work of an expert, and its simplicity and clearness are the result of a thorough mastery of the subject." -Scottish Field.

\section{By FRANK FINN, B.A., F.Z.A.

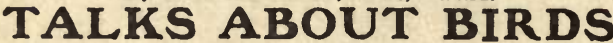

Containing 36 Illustrations, 16 of which are Full-page in Colour. Small square demy 8 vo, cloth, gilt top. Price $6 \mathrm{~s}$

"It is written in a most interesting style, and is sure to captivate intelligent boys and girls." -Western Morning News.

"Of exceptional interest and worth, as being on quite unusual lines."-Aberdeen Free Press.

\section{By J. H. FABRE

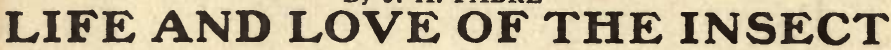

Translated by Alexander Teixeira De Mattos. Containing 26 Illustrations, 1 i of them Full-page from Photographs. Price $5 s$ net (by post $5 \mathrm{~s} 4 \mathrm{~d}$ ).

"Rarely have we come across a book on natural history written so attractively. He invests his subject with a fascination which should attract many readers who are now outside the ranks of students of natural history. The illustrations are excellent and most illuminating."-County Gentleman.

\section{By C. VON WYSS}

Crown 4to. Canvas boards, Price $186 \mathrm{~d}$ each

\section{GARDENS IN THEIR SEASONS}

Containing 58 Illustrations, 32 of which are in Colour with a Picture in Colour on the cover

"The little folk who are tempted from the gay pictures to the attractive letterpress which describes them, will meet here one of those born gardeners of the seeds of knowledge, who become as children themselves to open out to the little ones a glimpse of the poetry of earth."-Athenaum.

\section{BEASTS AND BIRDS}

Containing 55 Illustrations, $3 x$ of which are in Colour, with a Picture in Colour on the cover.

"This is described as a Nature Book for boys and girls, and would make a charming and welcome gift for children who are just old enough to learn about and be interested in animals. A short account of animals and their haunts and customs is given in simple straightforward language, and the profuse illustrations, both plain and coloured, with which the book is furnished, help to make the subject additionally clear and attrac. tive."-Sunday Times.

PUBLISHED BY

ADAM \& CHARLES BLACK, 4,5 \& 6 SOHO SQUARE, LONDON, W. 

THIS BOOK IS DUE ON THE IAST DATE STAMPED BELOW

\section{AN INITIAL FINE OF 25 CENTS} WILL BE ASSESSED FOR FAILURE TO RETURN THIS BOOK ON THE DATE DUE. THE PENALTY WILL INCREASE TO 50 CENTS ON THE FOURTH DAY AND TO \$1.00 ON THE SEVENTH DAY OVERDUE.

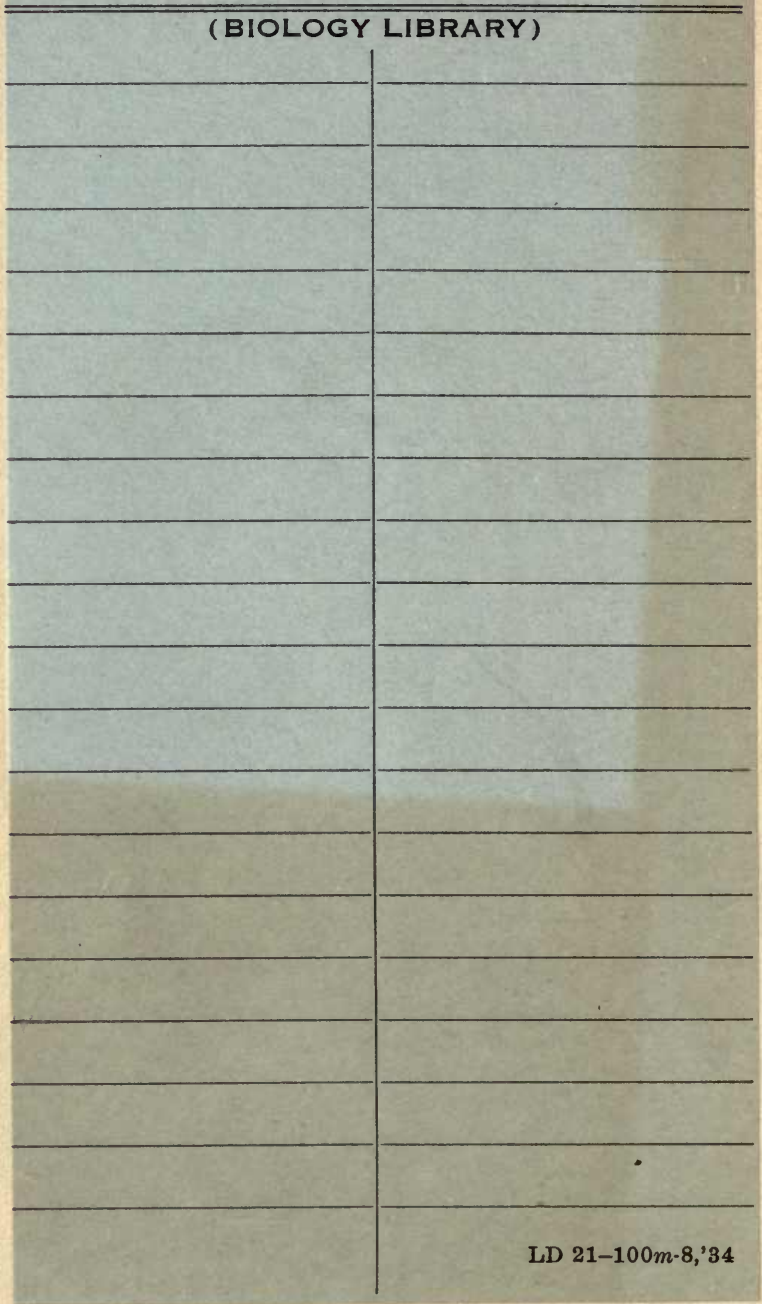




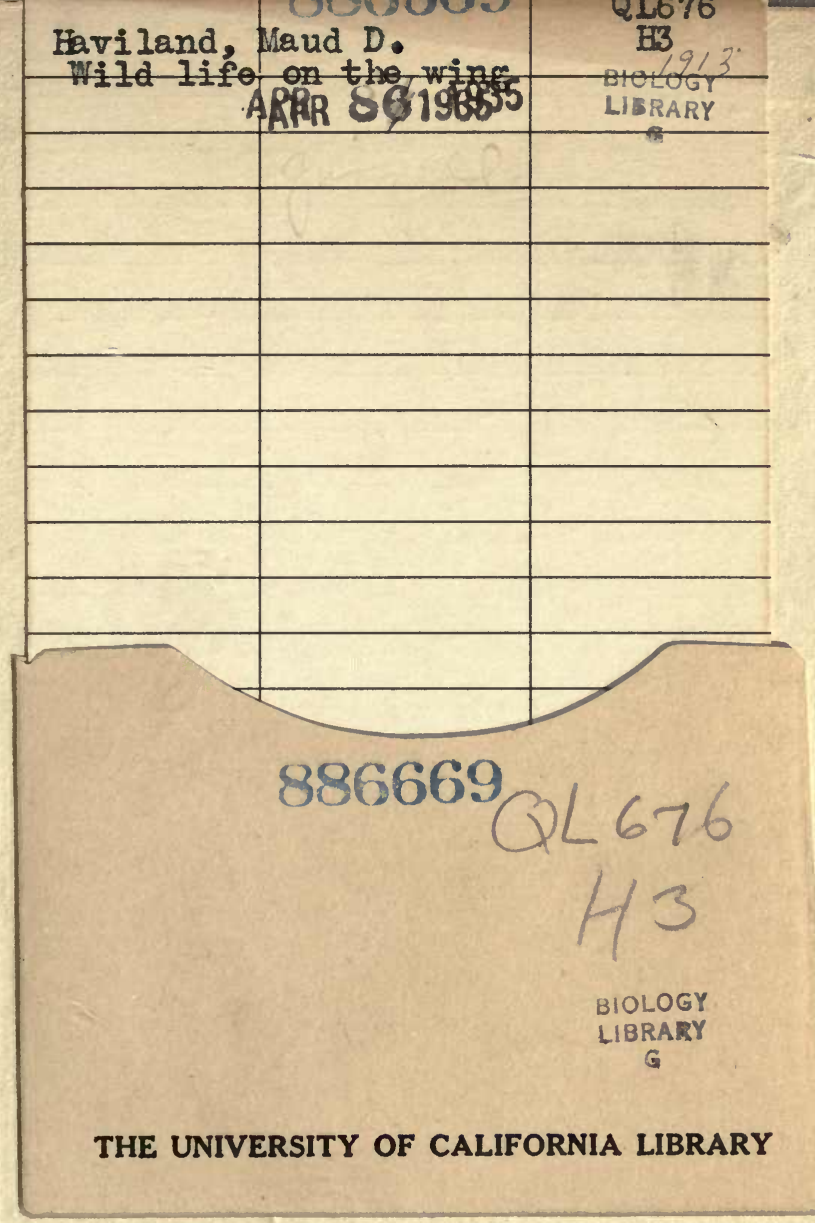


